\title{
REFORMAS INSTITUCIONAIS DO MERCADO DE CRÉDITO BANCÁRIO NO BRASIL (1999-2006): \\ UMA ANÁLISE JUS-SOCIOLÓGICA
}

Tese de doutorado em Filosofia e Teoria Geral do Direito, sob a orientação do Professor Titular José EduARdo CAMPOS DE OliveIRA FARIA.

Candidato: Emerson Ribeiro Fabiani

Universidade de São Paulo

Faculdade de Direito

São Paulo, janeiro de 2009 
Banca Examinadora 
À minha Lud 


\section{Agradecimentos}

Reconheço, primeiramente, a orientação atenta, ágil e próxima do Professor José Eduardo Faria, que me acompanha desde 1999, quando ingressei no PET Sociologia Jurídica da Faculdade de Direito da USP. A proximidade ao longo de quase dez anos fez com que eu pudesse comprovar o significado da dedicação à Universidade: a sua atuação transformadora da realidade do ensino e da pesquisa em direito no Brasil é prova disso, e a admiração de todos, uma decorrência justa.

Ressalto que os caminhos apontados pelos Professores Diogo Rosenthal Coutinho e Jean Paul Cabral Veiga da Rocha, na banca de qualificação e em outras oportunidades de discussão acadêmica, foram fundamentais para a concretização deste trabalho.

Devo dizer que este trabalho não se realizaria sem o apoio constante e irrestrito dos Professores Ary Oswaldo Mattos Filho, Antonio Angarita e Paulo Clarindo Goldschmidt, Diretores da Escola de Direito de São Paulo da Fundação Getulio Vargas (Direito GV). A convivência com eles no enfretamento de desafios inerentes à implementação de qualquer projeto como o da Direito GV tem me influenciado decisivamente. Não poderia deixar de mencionar também o nome de Leandro Silveira Pereira, outro apoiador determinante, especialmente na minha carreira profissional. Em nome dele, agradeço a todos os colegas e alunos do GVlaw.

Agradeço também à Sociedade Brasileira de Direito Público (SBDP), instituição em que pude desenvolver muitas das ideias contempladas nesta tese. Agradeço, especialmente, ao Carlos Ari Sundfeld, à Roberta Alexandr Sundfeld e aos pesquisadores da Escola de Formação.

Sou muito grato aos colegas do Núcleo Direito e Democracia do CEBRAP. O ambiente de provocação intelectual me motivou bastante. Ao Marcos Nobre, faço um agradecimento em particular, pelo suporte em momentos decisivos. 
Agradeço à Secretaria de Assuntos Legislativos do Ministério da Justiça, pela qualidade das informações prestadas e pelo paciente atendimento de Humberto Caetano de Sousa.

Em algumas das instituições mencionadas, tive a oportunidade de conhecer pessoas muito generosas, que também contribuíram para a realização deste trabalho. Agradeço, especialmente, pelos comentários, sugestões e apoio de Adriana Ancona Faria, Alessandro Octaviani Luís, Camila Duran Ferreira, Fernando Rugitsky, Guilherme Figueiredo Leite Gonçalves, José Garcez Ghirardi, José Rodriguez Rodriguez, Marcos Paulo Verissimo, Mário Gomes Schapiro, Maria Lucia Padua Lima, Marta Machado, Oscar Vilhena Vieira, Paulo Todescan Lessa Mattos, Rafael Faiardo Domingos Vanzella, Rafael Francisco Alves e Tiago Machado Cortez. Ao Gui e ao Don, especialmente.

Pelos últimos detalhes, agradeço à Ana Luiza Ramazzina Ghirardi e à Mariana Almeida do Amaral.

Agradeço também a Fábio Ferreira Durço, Felipe de Paula, Fernanda Emy Matsuda, Fernando Francisco Antunes, Manuela Schreiber Silva e Sousa, Maher Hassan Musleh, Rodrigo Ribeiro de Sousa e Sandra Faria, pela amizade.

Agradeço a meus pais, Anália e Edson, e aos pais da Lud, Neusa e Lau, pelo apoio constante.

Fraternalmente, agradeço ao Zé Garcez.

Por fim, menciono o apoio incondicional da Lud, em tudo. 


\section{ÍNDICE de GRÁFICOS, QUADros E TABELAS}

\section{GRÁFICOS}

PÁGINA

1 - CRÉDITO COMO PROPORÇÃO DO PIB (2003)

13

2 - CUSTO DO CRÉDITO (2003)

14

3 - PROCESSO DE EXECUÇÃO: CITAÇÃO, PENHORA E EMBARGOS

80

\section{QUADROS}

PÁGINA

1 - PADRÃO DE ANÁLISE DAS MEDIDAS SELECIONADAS

2 - COURTS: REFERÊNCIAS PARA A MENSURAÇÃO DO NÍVEL DE FORMALIDADE PROCESSUAL

3 - BASE METOdolóGiCA Do PROJETO DoING Business (2004-2006)

4 - PROTEÇÃo DOS INTERESSES DO CREDOR: CATEGORIAS DE ANÁLISE

5 - MEDIDAS PROPOSTAS E DESDOBRAMENTOS

46

6 - MEDIDAS POR DOCUMENTO

47

7 - PADRÃO DE ANÁLISE DA CÉDULA DE CRÉDITO BANCÁRIO 54

8 - PADRÃO DE ANÁLISE DA ALIENAÇÃO E DA CESSÃO FIDUCIÁRIAS 59

9 - PADRÃO DE ANÁLISE DO ACORDO PARA COMPENSAÇÃO DE PAGAMENTOS (SPB)

10 - PADRÃO DE ANÁLISE DO ACORDO PARA COMPENSAÇÃO DE PAGAMENTOS 64 (MERCADO DE BALCÃO)

11 - PADRÃO DE ANÁLISE DA CONSIGNAÇÃO EM FOLHA 68

12 - PADRÃO DE ANÁLISE DA REFORMA DA LEI DE FALÊNCIAS 78

13 - PADRÃO DE ANÁLISE DA RACIONALIZAÇÃO DOS PROCESSOS JUDICIAIS 86

14 - FINANCIAMENTO DA REFORMA DO MERCADO DE CRÉDITO PELO BANCO MUNDIAL

\section{TABELAS}

PÁGINA

1 - BRASIL: RECEITAS INFLACIONÁRIAS DAS INSTITUIÇÕES FINANCEIRAS 15

2 - ÍNDICE DE RECORRIBILIDADE EXTERNA 


\section{Lista DE Abreviações}

\begin{tabular}{|c|c|}
\hline ADIn & $\begin{array}{l}\text { Ação Direta de } \\
\text { Inconstitucionalidade }\end{array}$ \\
\hline BCB & Banco Central do Brasil \\
\hline BM & Banco Mundial \\
\hline BNDES & $\begin{array}{l}\text { Banco Nacional de } \\
\text { Desenvolvimento Econômico e } \\
\text { Social }\end{array}$ \\
\hline CETIP & $\begin{array}{l}\text { CETIP S.A. - Balcão } \\
\text { Organizado de Ativos e } \\
\text { Derivativos }\end{array}$ \\
\hline Cooperpoa & $\begin{array}{l}\text { Cooperativa de Economia e } \\
\text { Crédito Mútuo dos Servidores } \\
\text { Públicos Municipais de Porto } \\
\text { Alegre }\end{array}$ \\
\hline Cosif & $\begin{array}{l}\text { Plano Contábil das Instituições } \\
\text { Financeiras }\end{array}$ \\
\hline CPC & Código de Processo Civil \\
\hline CTN & Código Tributário Nacional \\
\hline CVM & $\begin{array}{l}\text { Comissão de Valores } \\
\text { Mobiliários }\end{array}$ \\
\hline DEPEP & $\begin{array}{l}\text { Departamento de Estudos e } \\
\text { Pesquisas }\end{array}$ \\
\hline DOC & Documento de Crédito \\
\hline EC & Emenda Constitucional \\
\hline ECGI & $\begin{array}{l}\text { European Corporate Governance } \\
\text { Institute }\end{array}$ \\
\hline EREsp & $\begin{array}{l}\text { Embargos de Divergência em } \\
\text { Recurso Especial }\end{array}$ \\
\hline GNI & Gross National Income \\
\hline IBGE & $\begin{array}{l}\text { Instituto Brasileiro de Geografia } \\
\text { e Estatística }\end{array}$ \\
\hline IBRADEMP & $\begin{array}{l}\text { Instituto Brasileiro de Direito } \\
\text { Empresarial }\end{array}$ \\
\hline
\end{tabular}

\begin{tabular}{|c|c|}
\hline INSS & $\begin{array}{l}\text { Instituto Nacional do Seguro } \\
\text { Social }\end{array}$ \\
\hline IPEA & $\begin{array}{l}\text { Instituto de Pesquisa Econômica } \\
\text { Aplicada }\end{array}$ \\
\hline MPV & Medida Provisória \\
\hline NBER & $\begin{array}{l}\text { National Bureau of Economic } \\
\text { Research }\end{array}$ \\
\hline $\mathrm{NCC}$ & Novo Código Civil \\
\hline PIB & Produto Interno Bruto \\
\hline PJSB & $\begin{array}{l}\text { Projeto "Juros e Spread } \\
\text { Bancário" }\end{array}$ \\
\hline PL & Projeto de Lei \\
\hline PPP & $\begin{array}{l}\text { Purchasing Power Parity } \\
\text { (Paridade de Poder de Compra) }\end{array}$ \\
\hline PROES & $\begin{array}{l}\text { Programa de Incentivo à } \\
\text { Redução do Setor Público } \\
\text { Estadual na Atividade Bancária }\end{array}$ \\
\hline Resp & Recurso Especial \\
\hline RMCLP & $\begin{array}{l}\text { Reformas Microeconômicas e } \\
\text { Crescimento de Longo Prazo }\end{array}$ \\
\hline SPB & $\begin{array}{l}\text { Sistema de Pagamentos } \\
\text { Brasileiro }\end{array}$ \\
\hline SPE & $\begin{array}{l}\text { Secretaria de Política Econômica } \\
\text { do Ministério da Fazenda }\end{array}$ \\
\hline SRJ/MJ & $\begin{array}{l}\text { Secretaria da Reforma do } \\
\text { Judiciário do Ministério da } \\
\text { Justiça }\end{array}$ \\
\hline STF & Supremo Tribunal Federal \\
\hline STJ & Superior Tribunal de Justiça \\
\hline TED & $\begin{array}{l}\text { Transferência Eletrônica } \\
\text { Disponível }\end{array}$ \\
\hline
\end{tabular}




\section{SUMÁRIO}

1.1 DA MACROECONOMIA AO DIREITO

1.2 DELIMITAÇÃO DO OBJETO

1.3 O DIREITO COMO PRECONDIÇÃO PARA O DESENVOLVIMENTO CAPITALISTA 24

1.3.4 CATEGORIAS DE ANÁLISE

2 O DIREITO COMO MEIO PARA A REDUÇÃO DO SPREAD BANCÁRIO NO BRASIL $\quad 45$

2.1 CRIAÇÃO DA CÉDULA DE CRÉDITO BANCÁRIO 48

2.2 AUMENTO DO ALCANCE DA ALIENAÇÃO E DA CESSÃO FIDUCIÁRIAS

2.3 RECONHECIMENTO DO ACORDO PARA COMPENSAÇÃO DE PAGAMENTOS 60

2.4 PREVISÃO LEGAL DO CRÉDITO CONSIGNADO EM FOLHA DE PAGAMENTO 64

2.5 REFORMA DA LEI DE FALÊNCIAS

2.6 RACIONALIZAÇÃO DOS PROCESSOS JUDICIAIS

3 DIREITO, ECONOMIA E POLÍTICA: AS INTERFACES DA DOTAÇÃO INSTITUCIONAL 88

3.1 A REFORMA DO MERCADO DE CRÉDITO BRASILEIRO EM DOCUMENTOS DO BANCO MUNDIAL 88

3.2 O DIREITO DA DOTAÇÃO INSTITUCIONAL: CONSIDERAÇÕES METODOLÓGICAS 96

3.3 O DIREITO DA DOTAÇÃO INSTITUCIONAL: PRESSUPOSTOS TEÓRICOS 104

\begin{tabular}{ll} 
CONCLUSÃO & 112 \\
\hline
\end{tabular}

BIBLIOGRAFIA CITADA $\quad 117$

\begin{tabular}{ll} 
RESUMO & 142 \\
\hline
\end{tabular}

\begin{tabular}{ll} 
ABSTRACT & 143 \\
\hline
\end{tabular}

RÉSUMÉ 


\section{INTRODUÇÃ̃o}

São cada vez mais comuns os estudos que apontam as instituições como fatores de primeira grandeza para o crescimento econômico. ${ }^{1}$ São abundantes, também, as pesquisas que relacionam o nível de desenvolvimento de um país à profundidade do seu mercado financeiro. ${ }^{2}$ Nesse campo, quando o assunto é reforma para o desenvolvimento do mercado de crédito, as instituições jurídicas são frequentemente apontadas como responsáveis fundamentais pela garantia de certeza para o ambiente de negócios. ${ }^{3}$

No Brasil, o mercado de crédito bancário é especialmente importante por se tratar da principal fonte de financiamento de pessoas físicas e jurídicas. Apesar de sua relevância, tal mercado tem sido descrito como sendo de alto custo e de reduzido tamanho, vez que apresenta um dos spreads de taxas de juros ${ }^{4}$ mais altos do mundo e um volume de crédito concedido muito abaixo daquele que seria condizente com o nível da renda nacional. ${ }^{5}$ Esse diagnóstico e as premissas brevemente apontadas no parágrafo anterior parecem ter orientado as recentes reformas do mercado de crédito brasileiro: transformações no regime jurídico de proteção aos direitos dos credores e nos mecanismos utilizados para fazer valer a lei e os contratos foram apontadas como instrumentos privilegiados para gerar um clima mais propício ao investimento

\footnotetext{
${ }^{1}$ Textos da Nova Economia Institucional costumam empregar o termo instituição para designar um conjunto de regras que têm por função "reduzir a incerteza, simplificar a tomada de decisão e promover a cooperação entre atores" e, com isso, reduzir custos de transação. Cf. FuRUBOTN, E.; RICHTER, R. Institutions and Economic Theory: The Contribution of the New Institutional Economics. 2. ed. Michigan: University of Michigan, 2005, p. 7. Sobre o papel das instituições no desenvolvimento econômico, cf. NORTH, D. Institutions, Institutional Change, and Economic Performance. New York: Cambridge University, 1990.

${ }^{2}$ Levine, R.; Zervos, S. Stock Markets, Banks, and Economic Growth, American Economic Review, 88 (3), p. 537-558, 1998; e RAJAN, R.; ZINGALES, L. Financial Dependence and Growth, American Economic Review, 88 (3), p. 559-586, 1998; DemirgüÇ-Kunt, A.; MAKSIMOVIC, V. Law, Finance, and Firm Growth, Journal of Finance, 53, p. 2107-2137, 1998.

${ }^{3}$ Dentre outros: ARIDA, P.; BACHA, E. L.; LARA-RESENDE, A. Credit, Interest, and Jurisdictional Uncertainty: Conjectures on the Case of Brazil. In: GiavaZzI, F.; Goldfajn, I. (eds.) Inflation Targeting and Debt: the Case of Brazil, Cambrigde: MIT, 2004, p. 265-293; PinHeIRO, A. C.; CABRAL, C. Mercado de crédito brasileiro: o papel do Judiciário e de outras instituições. Rio de Janeiro: BNDES, 1998; BID -Banco Interamericano de Desenvolvimento. Libertar o crédito: como aprofundar e estabilizar o financiamento bancário. Rio de Janeiro: Elsevier, 2005.

${ }^{4}$ Diferença entre as taxas de captação pagas aos depositantes e as taxas cobradas dos tomadores de empréstimos. Sobre a comparabilidade de spreads entre países, cf. NAKANE, M.; COSTA, A. C. Spread bancário: os problemas da comparação internacional. In: BCB - Banco Central do Brasil. Relatório de economia bancária e crédito. Brasília, 2005, p. 59-68.

${ }^{5}$ BID - Banco Interamericano de Desenvolvimento. Libertar o crédito. 2005. p. 6-7.
} 
privado e, com isso, diminuir custos de transação e aumentar o fluxo de crédito para o financiamento da atividade econômica. ${ }^{6}$

É a partir desse quadro que este trabalho tem por objetivo apreender as expectativas em relação ao direito presentes em documentos oficiais do Banco Central do Brasil (BCB) que sugeriram, entre 1999 e 2006, medidas para a reforma do mercado de crédito brasileiro. Os objetivos amplos dessa reforma foram: diminuir o custo do crédito, aumentar o volume de empréstimos concedidos e ampliar a diversidade de instrumentos de crédito. Do universo de medidas sugeridas, foram selecionadas aquelas voltadas especificamente para a transformação dos sistemas de insolvência e de cobrança de dívidas, tidos como os mais relevantes para o desenvolvimento financeiro.

A base de análise desta pesquisa serão os relatórios anuais do Projeto Juros e Spread Bancário (PJSB), elaborados pelo Departamento de Estudos e Pesquisas do BCB. Por razões que serão expostas oportunamente, também servirá de corpus o texto Reformas microeconômicas e crescimento de longo prazo, preparado pela Secretaria de Política Econômica do Ministério da Fazenda (SPE/MF).

Além desta introdução, este trabalho conta com quatro partes. Na primeira, é apresentado um panorama recente do comportamento do mercado de crédito brasileiro, privilegiando-se a apresentação das hipóteses explicativas para os baixos volumes e para os altos custos do crédito no Brasil. Com isso, será ilustrada uma virada da Economia em direção ao Direito, que passa a ocupar posição de destaque no rol de condições necessárias para o crescimento econômico sustentado. Essa virada é associada à assunção de uma perspectiva específica de direito, denominada dotação institucional, que encontra sua formulação mais recente na linha da literatura econômica conhecida como Law and Finance. Além do contexto e da conceituação de dotação institucional, o capítulo 1 também expõe os critérios utilizados

\footnotetext{
${ }^{6}$ BCB - Banco Central do Brasil. Juros e spread bancário no Brasil. Brasília, 1999, 2000, 2001; BCB - Banco Central do Brasil. Economia bancária e crédito. Brasília, 2002, 2003, 2004; BCB - Banco Central do Brasil. Relatório de economia bancária e crédito. Brasília, 2005 e 2006. Todos disponíveis em: http://www.bcb.gov.br/?SPREAD; SPE/MF - Secretaria de Política Econômica do Ministério da Fazenda. Reformas microeconômicas e crescimento de longo prazo. Brasília, 2004. Disponível em: http://www.fazenda.gov.br/spe/publicacoes/reformasinstitucionais/estudos/Texto_VersaoFinal5.pdf.
} 
para a seleção das medidas consideradas relevantes para esta pesquisa e apresenta a forma pela qual essas medidas serão analisadas.

No segundo capítulo, serão apresentadas e analisadas seis medidas de reforma do mercado de crédito, sugeridas e implementadas de 1999 a 2006. Os argumentos apresentados no corpo dos documentos para a implementação dessas medidas serão contrapostos com demandas encontráveis nas formulações da perspectiva da dotação institucional. Dessa forma, o objetivo desse capítulo será responder, medida a medida, à seguinte pergunta: quais são as expectativas em relação ao direito que podem ser depreendidas dos documentos oficiais objeto dessa pesquisa?

Por sua vez, o terceiro capítulo examinará algumas das premissas estruturadoras do direito na perspectiva da dotação institucional. O objetivo específico desse capítulo será melhor compreender qual concepção de direito as medidas de reforma do mercado de crédito pressupõem.

Uma breve conclusão encerrará o trabalho. Lá, será explicitada a trajetória da pesquisa e serão arrolados os principais resultados obtidos em sua execução. 


\section{MERCADO DE CRÉDITO BRASILEIRO: O PROBLEMA EM SEU CONTEXTO}

Este capítulo tem três objetivos: (a) fazer uma breve caracterização do estado do mercado de crédito brasileiro; $(b)$ expor os critérios utilizados para a seleção das medidas consideradas relevantes para esta pesquisa; e, por fim, $(c)$ apresentar a forma pela qual será analisado o grupo específico de medidas de reforma desse mercado.

\subsection{Da macroeconomia ao direito}

Indicadores comparativos de custos de financiamento em países com níveis similares de desenvolvimento, bem como dados sobre volume de crédito concedido, mostram que o mercado de crédito no Brasil é pouco desenvolvido, ${ }^{7}$ como se pode depreender dos gráficos que seguem.

Gráfico 1 - Crédito como proporção do PIB (2003) ${ }^{8}$

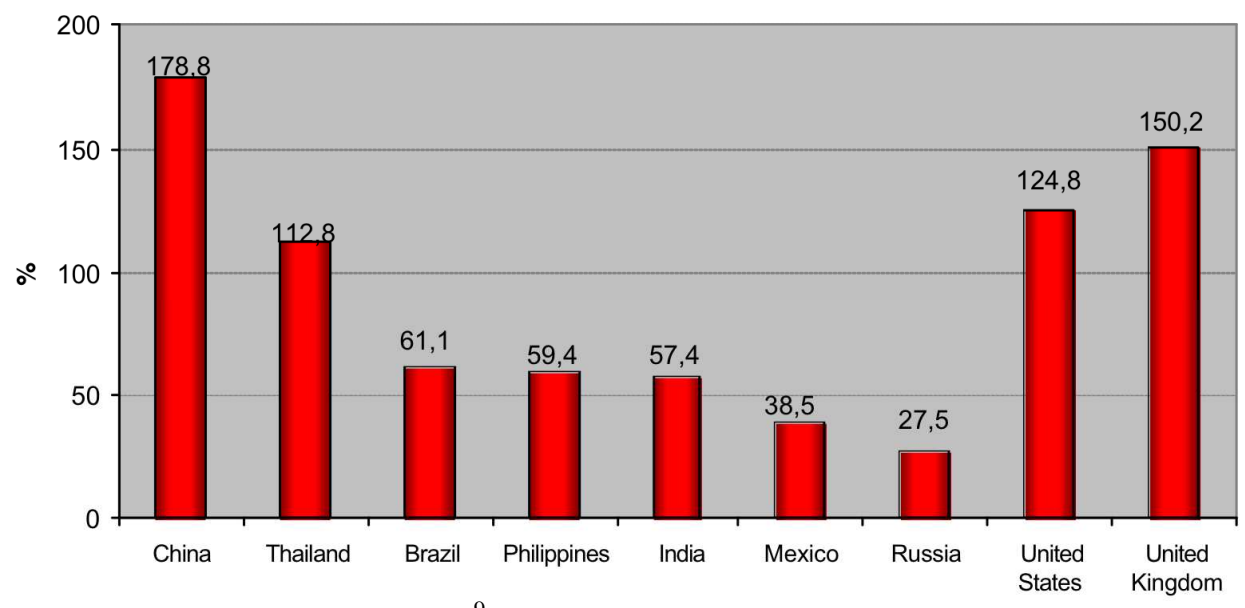

Fonte: Banco Mundial. ${ }^{9}$

\footnotetext{
${ }^{7}$ BCB, Juros e spread bancário no Brasil, 1999, 2000, 2001; BCB, Economia bancária e crédito, 2002, 2003, 2004; BCB, Relatório de economia bancária e crédito, 2005, 2006; SPE/MF, Reformas microeconômicas e crescimento de longo prazo, 2004; Arida, Bacha e Lara-Resende, Credit, interest, and jurisdictional uncertainty, 2004, p. 265-293; Pinheiro e Cabral, Mercado de crédito brasileiro, 1998, especialmente, p. 8-21; BID, Libertar o crédito, 2005, p. $5-7$.

${ }^{8}$ Inclui crédito dos segmentos livre e direcionado.

${ }^{9}$ Brazil: Investment Climate Assessment, 2005, v. 2, p. 85. Disponível em: <http://www.enterprisesurveys.org/documents/enterprisesurveys/ICA/Brazil Volume\%20I.pdf $>$. Acesso em 15 dez. 2008.
} 
Gráfico 2 - Custo do crédito (2003)

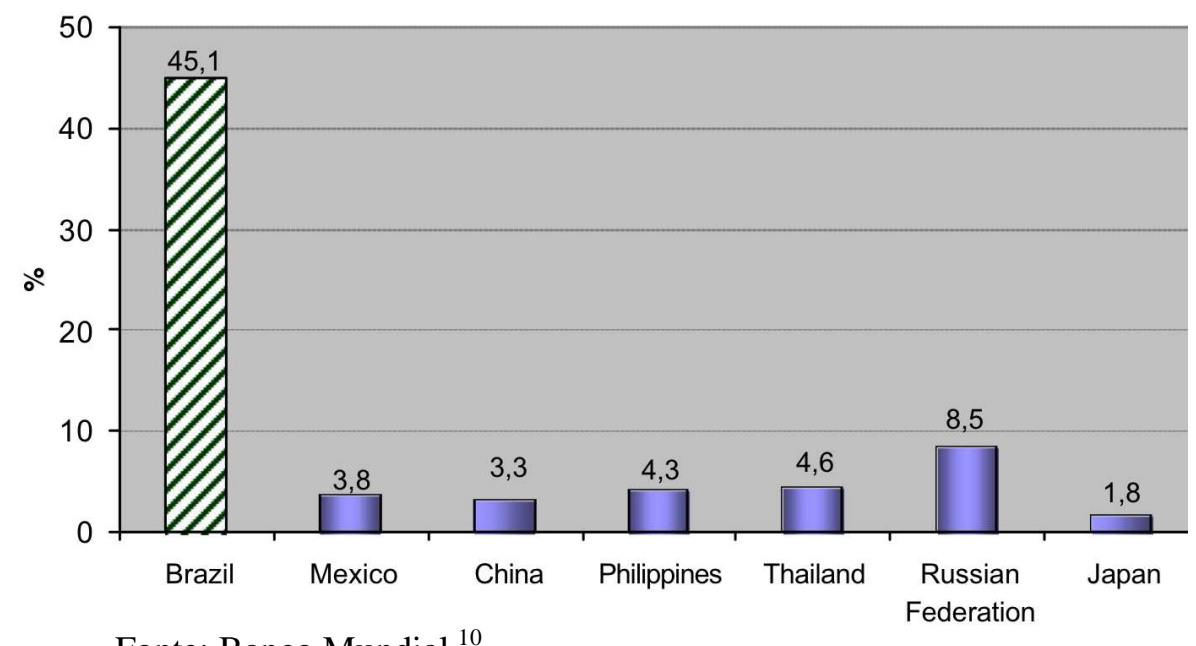

Fonte: Banco Mundial. ${ }^{10}$

Ao longo da década de 1990, três eventos criaram a expectativa de reversão desse cenário de baixo volume de concessão e alto custo de crédito: $(a)$ a estabilização de preços, alcançada com a implementação do Plano Real, a partir de julho de 1994; (b) a maior abertura do sistema financeiro nacional para a participação de bancos estrangeiros, anunciada em agosto de 1995; e (c) mudanças no tripé da política macroeconômica, no início de 1999. As expectativas de reversão foram frustradas nas três ocasiões.

Ao mesmo tempo em que trouxe a inflação para patamares aceitáveis, o Plano Real gerou um efeito adverso para o setor bancário: a perda de receitas de floating. ${ }^{11}$ Até 1994, as transferências inflacionárias respondiam por parcela bastante relevante do total de receitas bancárias. Conforme se pode observar da Tabela 1.1, houve ano em que essas transferências chegaram a representar $67,7 \%$ do total de receitas dos bancos públicos. Essa representatividade fez com que os bancos comerciais, ao longo das décadas de 1970 e 1980, se organizassem de modo a maximizar a geração de receitas com a inflação, o que significou enfocar sua atividade na captação de depósitos à vista. ${ }^{12}$ Eles contavam, assim, com uma

\footnotetext{
${ }^{10}$ Brazil: Investment Climate Assessment, 2005, p. 87.

${ }^{11}$ Aplicação de recursos em trânsito dentro do banco. Por serem potencializadas pela inflação, essas receitas também são conhecidas como transferências inflacionárias.

${ }^{12}$ PugA, F. Sistema Financeiro Brasileiro: reestruturação recente, comparações internacionais e vulnerabilidade à crise cambial. In: GiamBIAgI, F.; MOREIRA, M. A economia brasileira nos anos 90. Rio de Janeiro: BNDES, 1999, p. 415-16.
} 
ampla rede de agências, voltadas prioritariamente a receber pagamentos de títulos e depósitos de cheques. A concessão de crédito ficou relegada a segundo plano. ${ }^{13}$

Ao adotar um modelo de segmentação bancária similar ao vigente à época nos EUA (Glass-Steagall regulations), a própria Lei 4.595, de 31/12/1964, incentivou essa forma de organização, já que atribuiu aos bancos comerciais as funções de captação de depósitos à vista e de realização de operações de empréstimos de curto prazo. ${ }^{14}$ A despeito de a lei atribuir funções específicas para cada tipo de banco, a segmentação, no dia-a-dia de algumas instituições financeiras, dizia respeito somente à apresentação do planos contábeis distintos. Havia, inclusive, o compartilhamento de espaço entre instituições financeiras do mesmo conglomerado, cada qual especializada em um segmento. Em 1988, com a introdução do Plano Contábil das Instituições do Sistema Financeiro (Cosif), pelo Banco Central, e com a Resolução CVM 1.524, tornou-se possível a unificação de planos contábeis e a constituição de bancos múltiplos, dedicados a pelo menos duas das funções reservadas aos bancos pela Lei $4.595 / 1964 .^{15}$

Tabela 1 - Brasil: receitas inflacionárias das instituições financeiras ${ }^{16}$

\begin{tabular}{|c|c|c|}
\hline ANO & BANCOS PRIVADOS & BANCOS PÚBLICOS \\
\hline 1990 & $31,3 \%$ & $38,7 \%$ \\
\hline 1991 & $34,7 \%$ & $46,5 \%$ \\
\hline 1992 & $31,3 \%$ & $55,5 \%$ \\
\hline 1993 & $19,6 \%$ & $67,7 \%$ \\
\hline 1994 & $11,1 \%$ & $38,4 \%$ \\
\hline 1995 & $-0,9 \%$ & $2,5 \%$ \\
\hline
\end{tabular}

Fonte: Adaptado de Paula e Marques, 2006, p. 247.

\footnotetext{
${ }^{13}$ SOARES, R. Evolução do crédito de 1994 a 1999: uma explicação. Texto para discussão n. 808. Brasília: IPEA, jul. 2001, p. 5; PinheIro, A. C.; MourA, A. Segmentação e uso de informação nos mercados de crédito brasileiros. Texto para discussão n. 88, Rio de Janeiro: BNDES, fev. 2001, p. 7.

${ }^{14}$ Puga, Sistema Financeiro Brasileiro, 1999, p. 416.

${ }^{15}$ Puga, Sistema Financeiro Brasileiro, 1999, p. 416.

${ }^{16}$ Inclui os segmentos de bancos comerciais (caixas econômicas, inclusive) e de bancos múltiplos. Sobre os resultados negativos encontrados para bancos privados em 1995, Paula e Marques dizem que eles "resultam do forte aperto da política monetária nesse ano, traduzido num maior volume de recolhimento compulsório". Cf. Paula, L. F.; MARQues, M. B. Tendências recentes da consolidação bancária no Brasil. Porto Alegre, Revista Análise Econômica, v. 24, n. 45, 2006, p. 247.
} 
Com a estabilização de preços, esperava-se que esse quadro se alterasse e que os bancos procurassem compensar a perda de receitas de floating com a ampliação das operações de crédito. Houve, realmente, expansão do volume de crédito concedido, mas ela se deu apenas de forma temporária, e talvez em atenção à tendência de crescimento que já se verificava antes da implementação do Plano Real, e não como consequência necessária da estabilização de preços. ${ }^{17}$ Independentemente do que tenha causado a expansão do volume de crédito em circulação, é fato que ela cessou em 1995. O marco final dessa onda de crescimento foi a crise mexicana, deflagrada em dezembro de 1994.

As medidas adotadas pela autoridade monetária (Conselho Monetário Nacional e Banco Central do Brasil) para conter os riscos de propagação da crise mexicana pelo sistema bancário brasileiro incluíram a elevação da taxa básica de juros de $20 \%$ para $60 \%$ ao ano e a implementação de um amplo processo de consolidação bancária. ${ }^{18}$ Associadas à fase de adaptação dos bancos à ausência de transferências inflacionárias, essas medidas geraram uma grande retração na oferta de crédito e uma alta expressiva nos índices de inadimplência (créditos em atraso e em liquidação). Em resposta a esse quadro, foi anunciada, em agosto de 1995, a ampliação do grau de abertura do setor bancário ao capital estrangeiro. ${ }^{19}$ Tendo em conta que a Lei de Reforma Bancária, de 31/12/1964, faz a entrada de instituições financeiras estrangeiras no país depender de decreto do Poder Executivo, ${ }^{20}$ a Presidência da República deu um sinal claro ao mercado bancário ao declarar que passaria a "reconhecer como de interesse do Governo brasileiro a participação ou o aumento do percentual de participação de pessoas físicas ou jurídicas, residentes ou domiciliadas no exterior, no capital de instituições financeiras nacionais". ${ }^{21}$ Esse sinal era necessário por causa da prática vigente até então: a despeito de não existir regra escrita que assim dispusesse, o governo somente autorizava a participação estrangeira em bancos de investimento e em sociedades de arrendamento

\footnotetext{
${ }_{17}^{17}$ A esse respeito, cf. Soares, Evolução do crédito de 1994 a 1999, 2001, p. 11-21.

${ }^{18}$ A esse respeito, cf. Puga, Sistema Financeiro Brasileiro, 1999.

${ }^{19}$ Exposição de Motivos no 311, de 24/08/1995, do Ministério da Fazenda.

${ }^{20}$ Lei 4595/1964, artigo 18: “As instituições financeiras somente poderão funcionar no País mediante prévia autorização do Banco Central da República do Brasil ou decreto do Poder Executivo, quando forem estrangeiras."

${ }^{21}$ Exposição de Motivos no 311, citada por CARvalho, C.; VidotTo, C. Abertura do setor bancário ao capital estrangeiro nos anos 1990: os objetivos e o discurso do governo e dos banqueiros. Belo Horizonte, Nova Economia, v. 17, 2007, p. 403. Sobre as discussões dentro do governo a respeito da abertura, cf. Nova Economia.
} 
mercantil (leasing), e na condição de acionista minoritário. ${ }^{22}$ Os casos que fugiram a essa regra não escrita foram produto de acordos bilaterais que viabilizaram a expansão de bancos brasileiros no exterior e que, em contrapartida, permitiram o ingresso de bancos estrangeiros no mercado brasileiro. ${ }^{23}$

A justificativa para o maior grau de abertura era de matiz concorrencial: a entrada de bancos estrangeiros aumentaria a concorrência no setor bancário (especialmente pela difusão da eficiência administrativa e das técnicas de análise de risco de crédito, características dos bancos estrangeiros), faria com que o volume de crédito aumentasse e com que os juros ao tomador diminuíssem. Entretanto, a abertura não provocou mudanças significativas nem na oferta, nem no custo do crédito. ${ }^{24}$ Para Carvalho e Vidotto, os bancos estrangeiros pretendiam explorar o mercado brasileiro nas condições preexistentes, e não alterá-lo. ${ }^{25}$

As esperanças foram renovadas em 1999, quando o Governo brasileiro adotou três medidas para corrigir desajustes macroeconômicos: $(a)$ o programa de estabilidade fiscal, para ajuste das contas públicas, $(b)$ o regime de câmbio flutuante e $(c)$ o sistema de metas para inflação. Para além de serem respostas aos efeitos das crises russa e asiática, essas medidas foram adotadas como resposta a um diagnóstico que apontava os desequilíbrios no tripé da política macroeconômica como causas do reduzido volume de crédito em circulação, bem como de seus altos custos. Os problemas apontados eram: $(a)$ a ausência de superávit primário, (b) a superestimação da taxa de câmbio e (c) a manipulação indevida das taxas de juros com o objetivo de sustentar o nível de reservas internacionais. ${ }^{26}$ No período subsequente à adoção dessas medidas, as contas do Governo passaram a apresentar expressivo superávit primário, a taxa de câmbio variou para baixo, proporcionando superávit na balança comercial, e as taxas básicas de juros passaram a ser balizadas pelas metas de inflação. Com isso, o custo do crédito, num primeiro momento, baixou, mas não a patamares próximos aos de países com

\footnotetext{
${ }^{22}$ Puga, Sistema Financeiro Brasileiro, p. 425.

${ }^{23}$ Puga, Sistema Financeiro Brasileiro, p. 425.

${ }^{24}$ Carvalho e Vidotto, Abertura do setor bancário ao capital estrangeiro nos anos 1990, 2007, p. 422.

${ }^{25}$ Carvalho e Vidotto, Abertura do setor bancário ao capital estrangeiro nos anos 1990, 2007, p. 423.

${ }^{26}$ Arida, Bacha e Lara-Resende, Credit, Interest, and Jurisdictional Uncertainty, 2004, p. 265.
} 
níveis de desenvolvimento semelhantes ao do Brasil. ${ }^{27}$ E em 2001, a tendência de queda foi interrompida. $^{28}$

Foram apontados como responsáveis pela alta de juros no mercado de crédito: o conservadorismo da política monetária, que poderia obter os mesmos resultados no controle da inflação praticando juros mais baixos, a insuficiência do ajuste fiscal, que acabaria por atrair para as contas públicas recursos da poupança privada que poderiam financiar atividades produtivas, e, por fim, uma sequência de choques internos e externos na economia, a saber: o estouro da bolha especulativa das empresas de internet nos EUA, os ataques terroristas de 11 de setembro de 2001, o racionamento de energia elétrica ("apagão") e o chamado "risco Lula", crise de confiança gerada pelo temor de uma vitória do Partido dos Trabalhadores nas eleições presidenciais de $2002 .^{29}$

Em resumo, as explicações correntes durante a década de 1990 para o pouco desenvolvimento do mercado de crédito brasileiro são basicamente de ordem macroeconômica e, quando microeconômicas, de viés concorrencial. A partir de 1999, contudo, hipóteses de outra natureza começam a ser associadas a essas explicações. O diagnóstico que se passa a traçar, desde então, é o de que falhas institucionais também seriam fatores explicativos fundamentais para o parco desenvolvimento do mercado de crédito. ${ }^{30}$ Essa conjectura, cada vez mais difundida, aponta a debilidade do regime de proteção do investidor e a incapacidade do sistema judiciário de fazer valer contratos (falta de enforcement) como principais responsáveis pelo baixo volume e pelos altos custos do crédito em circulação. ${ }^{31}$

A incorporação desse argumento à discussão sobre crédito coincide com a ampla difusão de pesquisas empíricas que comparam o nível de desenvolvimento entre diferentes mercados financeiros nacionais e associam as diferenças ao papel desempenhado pelas

\footnotetext{
${ }^{27}$ Arida, Bacha e Lara-Resende, Credit, Interest, and Jurisdictional Uncertainty, 2004, p. 265.

${ }^{28}$ BCB, Economia bancária e crédito, 2002, p. 8.

${ }^{29}$ Hipóteses explicativas colecionadas por Arida, Bacha e Lara-Resende, Credit, Interest, and Jurisdictional Uncertainty, 2004, p. 266-268.

${ }^{30}$ Arida, Bacha e Lara-Resende, Credit, Interest, and Jurisdictional Uncertainty, 2004, p. 265, e Pinheiro e Cabral, Mercado de crédito brasileiro, 1998, p. 5-6.

${ }^{31}$ Arida, Bacha e Lara-Resende, Credit, Interest, and Jurisdictional Uncertainty, 2004, p. 266-268, e Pinheiro e Cabral, Mercado de crédito brasileiro, 1998, p. 5-7.
} 
instituições jurídicas de cada país estudado. Esses estudos asseveram que, nos países em que o sistema jurídico protege o direito de investidores e faz cumprir a lei, os mercados financeiros se desenvolvem, já que essas qualidades aumentam a disposição do poupador a investir. ${ }^{32}$

A hipótese inicial de pesquisa desse trabalho é que as reformas empreendidas no mercado de crédito brasileiro entre os anos de 1999 e 2006 foram feitas com base nessa leitura, a saber, a de que o direito é variável fundamental do desenvolvimento econômico. A forma de se enxergar a função desse direito é explorada na seção seguinte.

\subsection{Delimitação do objeto}

Como visto, são inúmeras as explicações para o estado de desenvolvimento do mercado de crédito brasileiro. Dentre outras, são apontadas: a forma de organização da indústria bancária, as incertezas provocadas por crises internacionais ou por crises internas de confiança, desajustes das contas públicas, falhas de regulação bancária, incongruência entre regras jurídicas (conteúdo e qualidade dos mecanismos de cumprimento) e os objetivos de proteção ao investidor. Obviamente, essas explicações não são autoexcludentes, de modo que não é afastada a possibilidade de que tenham concorrido para provocar o quadro descrito. $\mathrm{O}$ propósito deste trabalho, contudo, não é arbitrar o debate para dizer qual razão dá suporte a esse diagnóstico, muito menos questionar os fundamentos do diagnóstico. O objetivo é analisar um grupo de medidas de reforma do mercado de crédito apontado como tratamento para esse diagnóstico, a fim de mostrar que essas medidas incorporam uma visão específica de direito. A seguir são indicados os critérios de seleção e a forma de análise dessas medidas.

\footnotetext{
${ }^{32}$ Cf. LA PORTA, R. et al. Legal Determinants of External Finance, Journal of Finance, n. 52, p. 1131- 1150, 1997; LA PORTA, R. et al. Law and Finance, Journal of Political Economy, n. 106, p. 1113-1155, 1998; SHLEIFER, A.; VishnY, R. W. A Survey of Corporate Governance, Journal of Finance, v. 52, n. 2, p. 737-783, 1997; LA PORTA, R. et al. Investor Protection and Corporate Governance, Journal of Financial Economics, n. 58, p. 3-27, 2000; LA PORTA, R. et al. Investor Protection and Corporate Valuation, Journal of Finance, v. 57, n. 3, p. $1147-$ 1170, 2002; LA PORTA, R.; LóPEZ-DE-SilaneS, F.; ShleifER, A. Corporate Ownership Around the World, Journal of Finance, v. 54, n. 2, p. 71-517, 1999.

BECK, T.; LEVINE, R. Legal Institutions and Financial Development. In: MÉNARD, C.; SHIRLEY, M. (eds.) Handbook of New Institutional Economics. Dordrecht: Springer, 2005, p. 251-278; Shleifer e Vishny, A Survey of Corporate Governance, 1996.
} 


\subsubsection{Seleção dos dados}

O universo de medidas de reforma do mercado de crédito que é objeto desse trabalho foi definido em função de três critérios: $(a)$ veículo, $(b)$ tempo e $(c)$ matéria.

Antes de sumarizá-los, contudo, vale dizer que a expressão mercado de crédito, quando não qualificada, é empregada neste trabalho para designar o segmento livre do mercado de crédito, aquele em que os bancos têm liberdade para fixar taxas de juros que remuneram o aplicador de recursos. ${ }^{33}$ Assim, não serão incorporadas, nesta pesquisa, questões relativas ao segmento de crédito direcionado. Por isso, ela não se debruça sobre as modalidades de microcrédito, de financiamento habitacional e de financiamento rural. Assim também não menciona o papel dos correspondentes bancários e assuntos correlatos.

\subsubsection{Veículo}

O critério veículo leva em conta o documento de política que comunica as medidas propostas para a reforma do mercado de crédito. Para os fins desta pesquisa, foram analisados os relatórios anuais do Projeto Juros e Spread Bancário (PJSB) ${ }^{34}$ e o documento Reformas microeconômicas e crescimento de longo prazo $^{35}$.

Em 1999, logo depois de assumir a presidência do Banco Central do Brasil (BCB), Armínio Fraga criou o Departamento de Estudos e Pesquisas (DEPEP), com equipes em Brasília, no Rio de Janeiro e em São Paulo, cada qual dedicada a uma área temática específica. Enquanto os núcleos de Brasília e do Rio de Janeiro receberam a atribuição de dedicarem-se, respectivamente, ao sistema de metas de inflação e ao mercado de capitais (avaliação de riscos de mercado), a equipe de São Paulo ficou responsável por assuntos de economia bancária e de

\footnotetext{
${ }^{33}$ Sociedades de arrendamento mercantil, cooperativas de crédito e outras financeiras respondem por menos de $10 \%$ do crédito concedido no Brasil, daí o crédito bancário ter sido tomado como referência.

${ }^{34} \mathrm{BCB}$, Juros e spread bancário no Brasil, 1999, 2000, 2001; BCB, Economia bancária e crédito, 2002, 2003, 2004; BCB, Relatório de economia bancária e crédito, 2005, 2006.

${ }^{35} \mathrm{SPE} / \mathrm{MF}$, Reformas microeconômicas e crescimento de longo prazo, 2004.
} 
crédito. $^{36}$ Desde então, o DEPEP/SP passou a desenvolver o PJSB, com a finalidade de mapear as determinantes dos altos juros cobrados pelos bancos nas operações de crédito.

A cada ano, o DEPEP/SP publica um relatório desse projeto. Acompanhando os relatórios que procuram explicar o porquê do elevado spread bancário, os responsáveis pelo projeto propõem medidas para diminuir a grande diferença entre as taxas de captação e de aplicação praticadas pelos bancos.

Nos relatórios de 2003 e de 2004, os capítulos dedicados às medidas sugeridas pelo PJSB não representam a posição oficial do Governo a respeito da economia bancária. Diferentemente dos anos anteriores e subsequentes, esses capítulos foram assinados por técnicos e neles há a ressalva de que as opiniões ali expressas não refletem necessariamente a visão do BCB.

Para apreender a posição oficial do Governo nesses dois anos, foi selecionado o documento Reformas microeconômicas e crescimento de longo prazo, publicado em dezembro de 2004 pela Secretaria de Política Econômica do Ministério da Fazenda. Ele consolida medidas implementadas pelo governo do presidente Luiz Inácio Lula da Silva e apresenta uma agenda de propostas para que a economia brasileira entre num ciclo de crescimento sustentado.

\subsubsection{Tempo}

A adoção do regime de câmbio flutuante, em janeiro de 1999, é o marco inicial da pesquisa. Segundo Arida, Bacha e Lara-Resende, ${ }^{37}$ a mudança no regime de câmbio significou o ajuste do tripé macroeconômico. Como dito, esse ajuste resultou em diminuição das taxas de juros, mas não no nível esperado. Começaram a ganhar força, então, outras hipóteses explicativas para o fenômeno do reduzido desenvolvimento do mercado de crédito brasileiro.

\footnotetext{
${ }^{36}$ Informações prestadas por Eduardo Lundberg em entrevista realizada em 26 nov. 2008. Lundberg, funcionário de carreira do Banco Central do Brasil, coordenou o Projeto Juros e Spread Bancário de 1999 a 2004 e em 2006.

${ }^{37}$ Arida, Bacha e Lara-Resende, Credit, Interest, and Jurisdictional Uncertainty, 2004, p. 265.
} 
O primeiro relatório do PJSB, publicado em outubro de 1999, reflete esse quadro e já aponta problemas institucionais como corresponsáveis pelos altos custos do crédito no Brasil.

O marco temporal final de pesquisa é dado pela saída de Antônio Pallocci Filho do Ministro da Fazenda, em 27/03/2006.

Com esse recorte, será possível mapear as medidas propostas durante o segundo mandato do presidente Fernando Henrique Cardoso e o primeiro mandato do presidente Luiz Inácio Lula da Silva.

\subsubsection{Matéria}

Considerando como universo os veículos indicados no item 1.2.1.1, as medidas de reforma do mercado de crédito podem ser organizadas em três grandes grupos, conforme o propósito visado: ${ }^{38}(a)$ medidas voltadas à redução de incertezas macroeconômicas; $(b)$ medidas para o aumento da transparência e da concorrência no setor bancário; e, por fim, (c) reformas institucionais dos sistemas de insolvência e de cobrança de dívidas.

Como as medidas propostas com base no diagnóstico da falha institucional dialogam mais diretamente com o direito e dado o florescimento da literatura que aponta essa hipótese como a explicação mais fundamental para o diagnóstico apresentado no item 1.1, este trabalho concentrar-se-á, dentre as medidas propostas, nas reformas institucionais dos sistemas de insolvência e de cobrança de dívidas.

$\mathrm{O}$ anexo único traz o quadro com todas as medidas sugeridas pelos documentos de política mencionados no item 1.2.1.1. As medidas selecionadas são descritas e analisadas no capítulo 2.

\footnotetext{
${ }^{38}$ Cf. organização apresentada em BCB, Economia bancária e crédito, 2004, p. 31-37. Além das reformas do mercado de crédito, o documento Reformas microeconômicas e crescimento de longo prazo também apresenta medidas para aumento da qualidade da tributação, inclusão social, redução do custo de resolução de conflitos e melhora do ambiente de negócios. Cf. SPE/MF, 2004.
} 


\subsubsection{Organização dos dados}

Os dados coletados segundo os critérios indicados na subseção anterior foram organizados em quadro do seguinte padrão:

\section{Quadro 1 - Padrão de análise das medidas selecionadas}

\section{Medida proposta}

Título da medida proposta

Incidência

\begin{tabular}{|l|l|l|}
\hline Documento & Data & Status \\
\hline Título do documento que veicula a medida proposta & $\begin{array}{l}\text { Mês e ano do } \\
\text { documento que } \\
\text { veicula a medida }\end{array}$ & $\begin{array}{l}\text { Informe de } \\
\text { acompanhamento } \\
\text { da implementação } \\
\text { da medida }\end{array}$ \\
\hline
\end{tabular}

Objetivos

Finalidades a serem alcançadas com a implementação da medida proposta

Justificativas

Fundamentos da medida proposta

Referências citadas

Fontes bibliográficas expressamente citadas pelos documentos para embasar o diagnóstico apresentado ou para justificar a medida proposta

Observações

Informações adicionais julgadas relevantes

Com as informações assim organizadas, pretende-se testar a hipótese inicial de pesquisa enunciada na seção 1.1. 


\subsection{O direito como precondição para o desenvolvimento capitalista}

A hipótese de pesquisa aventada na seção 1.1 pode ser traduzida, em termos teóricos, como uma discussão sobre o papel das instituições jurídicas no desenvolvimento capitalista.

Esta seção do capítulo não tem a pretensão de recapitular toda literatura que relaciona direito e desenvolvimento capitalista. Seu objetivo é tão-somente o de apresentar uma das perspectivas dessa relação: a perspectiva da dotação institucional, que se tem tornado cada vez mais influente nos debates acadêmicos e políticos sobre o papel a ser desempenhado pelo direito na construção de regras pró-mercado. ${ }^{39}$

Milhaupt e Pistor assim definem essa perspectiva:

A rule of law to protect property rights and enforce contracts is an essential precondition to economic development because without it, transaction costs (in terms of unpredictability, enforcement problems, and so on) will be prohibitive in many cases. Thus, in the absence of legal order, markets will not grow and economies will falter". 40

Como se pode depreender dessa passagem, o direito é tomado como uma estrutura preordenada sem a qual não há desenvolvimento econômico: proteção aos direitos de propriedade e meios para que se possa fazer valer os contratos são precondições inerentes ao crescimento.

Por ter arrolado o direito racional como uma das precondições do capitalismo moderno, Max Weber é apontado por Milhaupt e Pistor como matriz dessa literatura. ${ }^{41}$ Uma associação mais estreita entre Weber e a perspectiva da dotação institucional, porém, não pode ser feita sem um certo grau de simplificação de leitura. Apesar de não estar no foco desta

\footnotetext{
${ }^{39}$ Milhaupt, C.; Pistor, K. Law and Capitalism: What Corporate Crises Reveal About Legal Systems and Economic Development Around the World. Chicago: University of Chicago, 2008, p. 17.

${ }^{40}$ Milhaupt e Pistor, Law and Capitalism, 2008, p. 17. Tradução livre: "Um ambiente de respeito à lei que proteja direitos de propriedade e faça valer contratos é precondição essencial para o desenvolvimento econômico porque, sem ele, os custos de transação (devido a problemas de imprevisibilidade, de efetivo respeito aos contratos e assim por diante) se tornarão, em muitos casos, proibitivos. Assim, na ausência de uma ordem jurídica, os mercados não crescerão e as economias irão vacilar."

${ }^{41}$ Milhaupt e Pistor, Law and Capitalism, 2008, p. 18.
} 
pesquisa, esta seção passará rapidamente por esse tema, apenas com o intuito de justificar a ausência de referências a Weber nas categorias de análise que serão associadas à perspectiva da dotação institucional. ${ }^{42}$

Para além do próprio Weber, esta seção abordará algumas das contribuições da Nova Economia Institucional, especialmente as de Douglass North e da literatura de Law and Finance. Essas contribuições podem ser agrupadas dentro da perspectiva da dotação institucional, que vê o direito como um investimento primeiro sem o qual não se pode dar início ao processo de desenvolvimento.

\subsubsection{O legado weberiano}

Dentre os autores clássicos das ciências sociais, foi Weber quem mais se ateve à investigação das influências recíprocas entre direito e economia para explicar o florescimento do capitalismo moderno. ${ }^{43}$ Dois dos seus conceitos sociológicos fundamentais são imprescindíveis para a compreensão do papel outorgado ao direito: ação social e relação social.

Se o termo ação designa qualquer comportamento humano dotado de sentido ${ }^{44}-$ seja ele um fazer, um não-fazer ou um permitir -, o conceito de ação social indica o comportamento humano que tem por referência o comportamento de outrem. Isto é, ação social é o comportamento humano cuja orientação (sentido) se reporta à ação de uma outra pessoa ou de outras pessoas. ${ }^{45}$ Ações sociais reciprocamente referidas constituem relações sociais. ${ }^{46}$ Uma relação social representa, assim, as ações sociais de pelo menos dois agentes

\footnotetext{
${ }^{42}$ Cf. seção 1.3.4.

${ }^{43}$ Nesse sentido: TrubeK. D. Max Weber sobre direito e ascensão do capitalismo. São Paulo, Revista Direito GV, v. 3, n. 1, 2007, p. 152.

${ }^{44}$ Quando Weber fala em sentido, quer ele referir-se ao "sentido subjetivamente visado", ou seja, à intenção que o agente busca atingir com certa ação. Cf. WEBER, M. Economía y sociedad: esbozo de sociología comprensiva. México: Fondo de Cultura Económica, 2002, p. 6.

${ }^{45}$ Weber, Economía y sociedad, 2002, p. 6.

${ }^{46}$ Weber, Economía y sociedad, 2002, p. 21.
} 
cujos sentidos se orientam mutuamente, de maneira que a conduta de um é determinada pela conduta do outro.

Diferentemente das leis da natureza, que descrevem relações causais necessárias, as relações sociais são marcadas por um coeficiente de indeterminação. É nesse sentido que se fala em probabilidade: nas relações sociais, pode-se dizer que em certas condições é provável que a ação social desenvolva-se nesse ou noutro sentido. Ou seja, no mundo das relações sociais não há certezas, mas tão-somente probabilidades. Isso não quer dizer que não possam ser identificadas regularidades, mas que essas regularidades nunca serão absolutas.

Pela perspectiva sociológica, o direito é visto por Weber como um meio para aumentar a probabilidade de que certas ações sociais ocorram de uma maneira determinada (aquela prescrita pelo direito). ${ }^{47} \mathrm{O}$ traço característico da ordem jurídica é a existência de um "un cuadro de individuos instituidos con la misión de obligar a la observancia de ese orden o de castigar su transgresión." ${ }^{48}$ Assim, em certo sentido, o direito funciona como mitigador da indeterminação das ações sociais.

Entre os intérpretes de Weber, parece não existir dúvida de que ele aponta a existência de uma ordem jurídica previsível como prerrequisito do capitalismo moderno. ${ }^{49}$ Os burgueses, diz Weber, demandavam

[...] un derecho inequívoco, claro, sustraído al arbitrio administrativo irracional, así como a las interferencias irracionales producidas por privilegios concretos, que garantice ante todo de manera segura la obligatoriedad de los contratos y, a consecuencia de tales propiedades, pueda ser previsible en su funcionamiento. ${ }^{50}$

\footnotetext{
${ }^{47}$ Como dito, essa é a visão de direito de Weber por uma ótica sociológica. Nesse sentido: SwEDBERG, R. Max Weber e a idéia de sociologia econômica, Rio de Janeiro/São Paulo: UFRJ; Beca, 2005, p. 178. Para uma visão jurídico-dogmática, vide Weber, Economía y sociedad, 2002, p. 251.

${ }^{48}$ Weber, Economía y sociedad, 2002, p. 27. Tradução livre: "quadro de indivíduos instituídos com a missão de fazer cumprir a ordem ou punir quem a transgredir."

${ }^{49}$ Trubek, Max Weber sobre direito e ascensão do capitalismo, 2007, p. 168; Swedberg, Max Weber e a idéia de sociologia econômica, 2005, p. 183; EWING, S. Formal justice and the spirit of capitalism: Max Weber's sociology of law, Law and Society Review, v. 21, n. 3, 1987, p. 491.

${ }^{50}$ Weber, Economía y sociedad, 2002, p. 628. Tradução livre: “[...] um direito inequívoco, claro, livre do arbítrio administrativo irracional, bem como das interferências irracionais produzidas por privilégios concretos, que garantisse de maneira segura a validade dos contratos e, em razão de todas essas propriedades, funcionasse de forma previsível." A despeito dessa demanda dos burgueses, Weber atribui o papel decisivo de criação do direito
} 
Contudo, o consenso entre os estudiosos de Weber parece desaparecer quando buscam determinar quais características do direito garantem a construção dessa ordem jurídica previsível. Na leitura de Trubek, por exemplo, Weber faz a previsibilidade decorrer da racionalidade lógico-formal. ${ }^{51}$

Como entende que o direito inglês é marcado por um grau reduzido de racionalidade lógico-formal, Trubek afirma que a hipótese weberiana não dá conta de explicar o papel do direito justamente no país em que o capitalismo deu seu salto qualitativo. ${ }^{52}$ A Inglaterra, seria, assim, um caso desviante da sua teoria sobre a ascensão do capitalismo no Ocidente. ${ }^{53}$

Swedberg discorda da leitura de Trubek e o acusa de igualar previsibilidade e racionalidade lógico-formal. Para ele, são três as precondições jurídicas apontadas por Weber para a ascensão do capitalismo: ${ }^{54}$ (a) o respaldo da ordem jurídica a contratos comerciais avançados; (b) a noção de empresa, dotada de personalidade jurídica própria, diferente da pessoa de seus membros; e, por fim, (c) uma ordem jurídica previsível. Acrescenta, ainda, que o termo previsibilidade designa: (i) respeito à propriedade e aos contratos, (ii) uma administração profissional da justiça e (iii) uma legislação clara e lógica, que torne previsíveis, inclusive, as transformações do próprio direito. ${ }^{55}$ Aqueles que dizem que estes prerrequisitos não estiveram presentes na Inglaterra, diz Swedberg, tomam o problema como exclusivamente

moderno à monarquia hereditária e aos juristas. Nesse sentido, Swedberg, Max Weber e a idéia de sociologia econômica, 2005, p. 184.

${ }^{51}$ Nas palavras do próprio Trubek: "Weber afirmava que o capitalismo requer uma organização normativa altamente calculável. Sua pesquisa sobre tipos de direito indicava que apenas o direito moderno e racional, ou a racionalidade lógico-formal, poderiam prover a calculabilidade necessária." "O que Weber quer dizer com 'racionalidade lógico-formal'? [...] O pensamento jurídico é racional, pois remete a alguma justificativa que transcende o caso concreto e se baseia em regras existentes e claramente definidas; é formal, pois os critérios de decisão são intrínsecos ao sistema de direito; e lógico, pois as regras e os princípios são deliberadamente construídos por formas especializadas de pensamento jurídico, baseados em uma classificação altamente lógica; também porque as decisões de casos específicos são tomadas por meio de processos lógico-dedutivos especializados que partem de princípios ou regras previamente estabelecidos." Cf. Trubek, Max Weber sobre direito e ascensão do capitalismo, 2007, p. 168 e 160, respectivamente.

${ }^{52}$ Trubek, Max Weber sobre direito e ascensão do capitalismo, 2007, p. 172-174, e Swedberg, Max Weber e a idéia de sociologia econômica, 2005, p. 185.

${ }^{53}$ Segundo Trubek, o próprio Weber, ao testar sua teoria, percebeu que ela não dava conta de explicar o caso inglês. A despeito disso, também segundo Trubek, ele nunca abandonou sua tese inicial. Cf. Trubek, Max Weber sobre direito e ascensão do capitalismo, 2007, p. 172.

${ }^{54}$ Swedberg, Max Weber e a idéia de sociologia econômica, 2005, p. 177-185.

${ }^{55}$ Swedberg, Max Weber e a idéia de sociologia econômica, 2005, p. 183. 
teórico e não buscam evidências na empiria. ${ }^{56}$ Ou seja, segundo esse autor, o "Problema da Inglaterra", tal como posto por Trubek, é descabido, já que se equivoca quem identifica previsibilidade com racionalidade lógico-formal e ignora a experiência concreta do direito inglês.

Note-se, contudo, que Weber aponta várias outras precondições para a ascensão do capitalismo que não são necessariamente jurídicas, dentre as quais: a apropriação dos meios materiais de produção como propriedade de livre disposição; a liberdade de mercado; a difusão de técnicas racionais na produção e na circulação de bens; a possibilidade de venda da força de trabalho; e a "comercialização da economia". ${ }^{57}$ Assim, conquanto o direito racional seja apontado como fundamental, a seu lado são arroladas outras cinco precondições. Por essa e por outras razões metodológicas, não parece isento de problemas o uso da obra de Weber para a construção da perspectiva da dotação institucional, como fazem Milhaupt e Pistor. De certa forma, esses dois autores chegam a admitir a existência de tais dificuldades em seu esforço de aproximar as ideias de Weber das premissas da dotação institucional. ${ }^{58}$ Em face disso, destacada a função basilar de Weber para a reflexão sobre direito e economia, essa tese privilegiará as contribuições de North e da Law and Finance para a construção da perspectiva da dotação institucional.

Seja como for, o debate em torno do problema da Inglaterra permite conectar as formulações weberianas com as discussões mais recentes sobre o papel do direito no desenvolvimento econômico, como a que se vê nas formulações de North.

\subsubsection{Douglass North: instituições e crescimento econômico de longo prazo}

\footnotetext{
${ }^{56}$ Swedberg, Max Weber e a idéia de sociologia econômica, 2005, p. 186. Ao se referir à noção de um direito calculável, previsível, Weber assevera: “[...] según la experiencia lo revela, esta necesidad puede ser satisfecha en la misma o mejor forma por un derecho empírico amorfo, ligado a precedentes" (Cf. Weber, Economía y sociedad, 2002, p. 635).

${ }^{57}$ WeBER, M. Historia Económica General. México: Fondo de Cultura Económica, 2001, p. 237-138.

${ }^{58}$ Milhaupt e Pistor, Law and Capitalism, 2008, p. 17. Sobre a apropriação da obra de Weber pelos teóricos que discutem os fatores jurídicos desencadeadores do desenvolvimento, cf. THOMAS, C. Re-Reading Weber in Law and Development: A Critical Intellectual History of "Good Governance" Reform. Cornell Law School Research Paper n. 08-034, 2008. Disponível em: <http://ssrn.com/abstract=1313718>. Acesso em: 15 dez. 2008.
} 
Não seria absurdo cogitar que a frase mais citada da obra de North seja "institutions matter". 59 O que significa, contudo, propalar que "as instituições importam”? Preocupado com a possível transitividade do verbo "importar", perguntaria um falante de português vernáculo: importa para quê? A frase marcante e as perguntas que ela desperta são os motes dessa subseção, que é dedicada a apresentar alguns dos pressupostos da história econômica segundo a visão de North, bem como situar uma outra vertente no debate sobre o papel do direito no desenvolvimento capitalista.

Ao defender a importância das instituições para compreender como as economias se transformam ao longo do tempo, North está a dialogar com os economistas neoclássicos. Segundo ele, por pressupor um mundo estático e sem atritos, a teoria neoclássica é capaz de explicar as operações do mercado, mas não as forças que levam ao desenvolvimento do mercado ${ }^{60} \mathrm{O}$ reconhecimento dessa limitação explicativa não significa, contudo, que North abandone completamente a teoria neoclássica: para ele, o indivíduo continua a ser a unidade de análise; a escassez de recursos continua a ser reconhecida como pressuposto teórico; e a microeconomia continua a ser a ferramenta analítica. ${ }^{61}$ Significa, sim, que North toma a teoria neoclássica com algumas modificações. Duas dessas modificações merecem especial destaque: (a) o reconhecimento da existência de custos de transação, o que afasta a presunção de um mundo sem atritos; e (b) a assunção da racionalidade limitada dos agentes econômicos, em oposição à hipótese neoclássica de racionalidade plena dos indivíduos. ${ }^{62}$

\footnotetext{
${ }^{59}$ O Google, por exemplo, traz 14.200 resultados para a busca que conjuga essa frase e o nome do seu autor. Fonte: www.google.com.br. Acesso em 30 out. 2008, com os seguintes critérios: "institutions matter" North. Outra passagem marcante da obra de North é "institutions are the rules of the game". Essa frase, conjugada com "North", traz 2.460 resultados no Google.

${ }^{60}$ NORTH, D. Economic performance through time. Prize Lecture - Lecture to the memory of Alfred Nobel, 9 dez. 2003, p. 1. Disponível em: http://nobelprize.org/nobel_prizes/economics/laureates/1993/north-lecture.html. Acesso em 30 out. 2008.

${ }^{61}$ North, Economic performance through time, 2003, p. 1, e NORTH, D. New Institutional Economics and Development. Department of Economics, Washington University, St. Louis, Missouri, p. 1, 1992, disponível em http://129.3.20.41/eps/eh/papers/9309/9309002.pdf.

${ }^{62}$ Segundo Furubotn e Richter, a racionalidade limitada não foi assumida pelos primeiros neoinstitucionalistas e também não se aplica a todos atualmente. Cf. FURUBOTN, E. e RICHTER, R. Institutions \& Economic Theory: The Contribution of the New Institutional Economics. 2 ed. Ann Arbor: University of Michigan, 2005, p. 4.
} 
Num modelo de racionalidade plena, a tomada de decisão é orientada pelo critério da maximização do bem-estar individual: pressupõe-se que o agente tenha conhecimento de todas as possibilidades de ação (informação perfeita); que ele tenha capacidade de classificá-las em função de sua utilidade; e, por fim, que ele escolha - instantaneamente e sem custos - o caminho que atenda mais adequadamente aos seus interesses, dentre as opções da sua lista inequívoca de prioridades. Nesse modelo, caso a escolha não seja a mais adequada, mecanismos de retroinformação (feedback) funcionarão como aprendizado para as próximas tomadas de decisão, que tenderão, por isso, a atingir o máximo de bem-estar.

Em reação a essa hipótese de racionalidade plena, North afirma que:

\begin{abstract}
Individuals possess mental models to interpret the world around them. These are in part culturally derived - that is produced by the intergenerational transfer of knowledge, values, and norms which vary radically among different ethnic groups and society. In part they are acquired through experience which is 'local' to the particular environment and therefore also varies widely with different environments. Consequently there is immense variation in mental models and as a result different perceptions of the world and the way it 'works'. And even the formal learning that individuals acquire frequently consists of conflicting models by which we interpret the world around us. 63
\end{abstract}

Em outras palavras: se as decisões dos indivíduos são tomadas com base em modelos mentais subjetivos, não há como pressupor racionalidade plena ou propensão para convergência, nem supor que as preferências sejam estáveis. ${ }^{64}$ As expectativas variam de indivíduo para indivíduo, não são necessariamente transparentes e sofrem mudanças no tempo. ${ }^{65}$ North fala, então, em racionalidade limitada, assumindo que o indivíduo não é capaz de processar mentalmente todas as suas possibilidades de ação, nem de antever o que acontecerá em razão de suas escolhas.

\footnotetext{
${ }^{63}$ North, New Institutional Economics and Development, 1992, p. 1-2. Tradução livre: "os indivíduos possuem modelos mentais para interpretar o mundo à sua volta. Tais modelos derivam em parte da cultura - que é produzida pela transferência de conhecimento entre as gerações, por valores e normas que variam radicalmente entre diferentes sociedades e grupos étnicos. Em parte, eles são adquiridos pela experiência que é 'local' em relação àquele ambiente específico e que, assim, também varia consideravelmente segundo o ambiente. Consequentemente, há uma enorme variação de modelos mentais, o que resulta em diferentes modos de perceber o mundo e entender o modo como ele funciona. E mesmo o conhecimento formal que os indivíduos adquirem consiste de modelos conflitantes de análise do mundo à nossa volta."

${ }^{64}$ Furubotn e Richter, Institutions \& Economic Theory, 2005, p. 4.

${ }^{65}$ North, Economic performance through time, 2003, p. 2.
} 
Num mundo sem atritos e de racionalidade plena, como aquele pressuposto pela economia neoclássica, os indivíduos podem, em tese, obter e processar, sem custos e instantaneamente, toda a informação desejada. ${ }^{66}$ Já no cenário considerado por North, a informação é um recurso escasso e sua obtenção, custosa. Reconhece-se, então, a existência de custos de transação - custos de avaliação dos atributos dos bens ou serviços que estão sendo transacionados, dos agentes que estão transacionando, além dos custos de negociação e de monitoramento da execução dos acordos feitos. ${ }^{67} \mathrm{~A}$ escassez de informação no curso da execução dos acordos feitos pode ensejar, por exemplo, problemas de risco moral, em que uma das partes, comportando-se de maneira oportunista, não emprega todo o esforço que poderia empregar para cumprir sua obrigação contratual. ${ }^{68}$

Conforme diz o próprio North, ${ }^{69}$ sua teoria das instituições é resultado da combinação de uma teoria do comportamento humano com uma teoria dos custos de transação: dado que as decisões são tomadas com base em modelos mentais limitados e em informação incompleta, é esperado que surjam incertezas a respeito do comportamento das contrapartes na interação humana. $^{70} \mathrm{O}$ papel das instituições é justamente reduzir essas incertezas e garantir a correspondência de certas expectativas. ${ }^{71}$ Assim, teleologicamente, as instituições podem ser definidas como conjunto de regras que delimitam as possibilidades de escolha dos indivíduos quanto às suas ações, criando um ambiente estável para a interação humana. ${ }^{72}$ Essas regras, que podem ser formais ou informais, guiam o comportamento individual mediante incentivos a condutas desejáveis e punições a comportamentos desviantes.

Contudo, por ser produto da mente humana, não há garantias de que uma instituição será necessariamente eficiente. ${ }^{73}$ A autoimposição de restrições ao comportamento é também um processo de tomada de decisão e, por isso, envolve as mesmas limitações de qualquer

\footnotetext{
${ }^{66}$ Furubotn e Richter, Institutions \& Economic Theory, 2005, p. 12.

${ }^{67}$ NORTH, D. Institutions, Institutional Change and Economic Performance. New York: Cambridge University, 1996, p. 27-35.

${ }^{68}$ A referência clássica sobre risco moral é STIGLITZ, J.; WEISS, A. Credit Rationing in Markets with Imperfect Information", American Economic Review, 71(3): 393-410, 1981.

${ }^{69}$ North, Institutions, Institutional Change and Economic Performance, 1996, p. 27.

${ }^{70}$ North, Institutions, Institutional Change and Economic Performance, 1996, p. 25.

${ }^{71}$ North, Institutions, Institutional Change and Economic Performance, 1996, p. 25.

${ }^{72}$ North, Institutions, Institutional Change and Economic Performance, 1996, p. 6.

${ }^{73}$ North, Institutions, Institutional Change and Economic Performance, 1996, p. 107 e p. 6.
} 
outra decisão, ou seja, informação incompleta e limitada capacidade de processamento mental. Independentemente de todas as dificuldades de mensuração, pode-se dizer que o resultado de uma mudança institucional é mais ou menos eficiente, dependendo do seu papel na redução das incertezas e dos custos de transação. ${ }^{74}$

Ainda segundo North, numa perspectiva de longo prazo, as instituições são determinantes fundamentais para explicar a diferença de desempenho entre países: "Third World countries are poor because the institutional constraints define a set of payoffs to political/economic activity that do not encourage productive activity."75 Já os países desenvolvidos, ao investirem em regras voltadas para a proteção dos direitos de propriedade e para o cumprimento dos contratos, cultivaram instituições capazes de fomentar o crescimento econômico. $^{76}$

Como a mudança institucional é tomada por North como path-dependent, escolhas ineficientes no passado poderão comprometer o rol de possibilidades no futuro e, com isso, o próprio crescimento de longo prazo. ${ }^{77}$ Nas palavras de Milhaupt e Pistor, "it is difficult for countries with a weak endowment to change the foundations for their future growth."78

North, assim, enfatiza as relações entre instituições, a previsibilidade de comportamentos e o desenvolvimento econômico. Tal ênfase dialoga com a construção de funções específicas para o Direito conforme propostas pelos teóricos da Law and Finance.

\footnotetext{
${ }^{74}$ Furubotn e Richter, Institutions \& Economic Theory, 2006, p. 7.

${ }^{75}$ North, Institutions, Institutional Change and Economic Performance, 1996, p. 110. Tradução livre: "Os países do Terceiro Mundo são pobres devido a limites institucionais que impõem ao desenvolvimento da atividade política/econômica uma série de compensações que não encorajam as atividades produtivas."

${ }_{77}^{76}$ Milhaupt e Pistor, Law and Capitalism, 2008, p. 18.

${ }^{77}$ North, Institutions, Institutional Change and Economic Performance, 1996, p. 112.

${ }^{78}$ Milhaupt e Pistor, Law and Capitalism, 2008, p. 18. Tradução livre: "é difícil para um país com debilidades de dotação mudar os fundamentos para seu crescimento futuro."
} 


\subsubsection{Law and Finance: direito dos credores e enforcement}

Como dito, esta seção tem por propósito apresentar uma visão específica da relação entre direito e desenvolvimento capitalista - a perspectiva da dotação institucional. Com esse mesmo intuito, essa subseção descreve sucintamente a corrente da literatura econômica conhecida como Law and Finance.

Na década de 1990, foram publicados inúmeros estudos que apresentavam evidências empíricas da correlação entre crescimento econômico e desenvolvimento financeiro. ${ }^{79}$ Independentemente das divergências sobre a direção da causalidade (se é o desenvolvimento do mercado financeiro que induz o crescimento econômico sustentado ou se é o crescimento econômico que demanda e, por isso, abre espaço para mercados financeiros mais profundos), esses estudos suscitaram, dentre outras, a seguinte questão: o que explica a diferença, de um país para outro, nos graus de desenvolvimento dos mercados financeiros $?^{80}$

Os textos da Law and Finance buscam responder a essa questão em dois níveis de análise. ${ }^{81}$ No primeiro, associam o grau de desenvolvimento dos mercados financeiros à qualidade do direito, apreciável pela presença de regras jurídicas que incentivam o investimento privado. No segundo, associam a variação na qualidade do direito em diferentes países às respectivas famílias jurídicas ${ }^{82}$ da qual deriva cada sistema nacional. ${ }^{83}$

\footnotetext{
${ }^{79}$ Levine e Zervos, Stock Markets, Banks, and Economic Growth, 1998; Demirgüç-Kunt e Maksimovic, Law, finance, and firm growth, 1998, p. 2107-2137; Rajan e Zingales, Financial Dependence and Growth, 1998. ${ }^{80}$ Beck e Levine, Legal Institutions and Financial Development, 2005, p. 251.

81 Armour, J.; DeAKIN, S.; SARKAR, P.; SiEMS, M; Singh, A. Shareholder Protection and Stock Market Development: an empirical test of the legal origins hypothesis, 2007, CBR Working Paper Series, p.3-4. Disponível em: http://ssrn.com/abstract=1094355. Acesso em 15 dez. 2008.

${ }^{82}$ Legal origins: tradições jurídicas, grandes sistemas de direito. A respeito, cf. DAVID, R. Os grandes sistemas do direito contemporâneo. 3. ed. São Paulo: Martins Fontes, 1998. A referência de La Porta et al., Law and Finance, 1998, é Reynolds, T.; Flores, A. Foreign Law: Current Sources of Codes and Basic Legislation in Jurisdictions of the World. Littleton: Rothman and Co., 1989.

${ }^{83}$ Como advertem BECK e LEVINE (2005, p. 253), há pesquisadores da Law and Finance theory que corroboram a tese de que a proteção do investidor ajuda no desenvolvimento do mercado financeiro e que rejeitam a visão de que a tradição jurídica seja uma determinante central para a proteção do investidor e para o consequente desenvolvimento do mercado financeiro. É o caso, por exemplo, de BECK, T.; DEMIRGÜÇ-KunT, A.; LEVINE, R. Law, Endowments, and Finance, Journal of Financial Economics, v. 70, n. 2, 2003, p. 137-181.
} 
Quanto maior a proteção jurídica, maior será o incentivo para o agente superavitário investir: ${ }^{84}$ esse é o ponto de partida da literatura da Law and Finance. No primeiro nível de análise, a Law and Finance sustenta que as diferenças no grau de desenvolvimento financeiro entre os países podem ser explicadas pela presença de determinada estrutura de incentivos nos ordenamentos jurídicos nacionais. Então, a Law and Finance busca identificar quais características do direito incentivam poupadores a investir recursos em projetos que demandam financiamento de terceiros para a geração de riqueza. Em linha com o pensamento de North, são apontadas as seguintes características: a clara definição de direitos de propriedade e um sistema eficiente para fazer valer os contratos privados (mecanismos de enforcement). ${ }^{85}$

Como se poderia esperar, o reconhecido pioneirismo da Law and Finance não decorre da repetição dessa lista genérica de características jurídicas prenunciadoras do desenvolvimento financeiro. Segundo três de seus autores mais representativos, La Porta, Lopez-de-Silanes e Shleifer, as grandes contribuições dos textos que inauguraram essa linha da literatura econômica foram, em primeiro lugar, o desenvolvimento de métodos para mensurar o grau de proteção jurídica dos investidores, e, por meio da aplicação desses métodos, a identificação de regularidades nas variações dos resultados entre os países pesquisados. $^{86}$

Para medir o grau de proteção jurídica dos investidores, esses textos construíram variáveis de análise com base em regras consideradas cruciais para a qualidade dos direitos de acionistas e de credores por "observadores da governança corporativa ao redor do mundo". 87

\footnotetext{
${ }^{84}$ LA PORTA, R.; LÓPEZ DE SILANES, F.; SHLEIFER, A. The Economic Consequences of Legal Origins, Journal of Economic Literature, v. 46, n. 2, jun. 2008, p. 285; Beck e Levine, Legal Institutions and Financial Development, 2005, p. 251. Ainda: La Porta et al, Legal Determinants of External Finance, 1997; La Porta et al, Law and Finance, 1998; La Porta et al, Investor Protection and Corporate Governance, 2000; Shleifer e Vishny, A Survey of Corporate Governance, 1996.

${ }^{85}$ La Porta et al, Law and Finance, 1998, p. 1114; Beck e Levine, Legal Institutions and Financial Development, 2005, p. 251-254.

${ }^{86}$ La Porta, López de Silanes e Shleifer, The Economic Consequences of Legal Origins, 2008, p. 285-286. Eles se referem aos textos La Porta et al, Legal Determinants of External Finance, 1997, e Law and Finance, 1998.

${ }^{87}$ La Porta et al, Law and Finance, 1998, p. 1121. São citadas as seguintes referências: ABA - American Bar Association. Multinational Commercial Insolvency. Chicago: ABA, 1989 e 1993; WHITE, M. The costs of corporate bankruptcy: the U.S.-European comparison. Ann Arbor: University of Michigan, 1993; INSTITUTIONAL Shareholder Services. Proxy Voting Guidelines. Washington: ISS Global Proxy Services, 1994; INVESTOR
} 
Em razão do objeto desta tese, dentre as variáveis para mensuração dos direitos dos investidores, o presente estudo concentra-se nas regras de proteção dos direitos dos credores, porque imediatamente relacionadas ao mercado bancário.

Num estudo que compara o grau de proteção dos direitos dos credores em 49 países, La Porta, Lopez-de-Silanes, Shleifer e Vishny valem-se de cinco variáveis: ${ }^{88}$

- Inexistência de suspensão automática das ações e execuções contra empresas em processo de recuperação, de forma que não haja impedimentos para que os credores com garantias tomem posse dos bens que respaldam seus créditos;

- Prioridade dos credores com garantia real no processo de falência, independentemente da existência de créditos trabalhistas ou fiscais;

- Existência de restrições, como o consenso dos credores, por exemplo, para que a empresa devedora possa pleitear o processo de recuperação;

- Administração da empresa durante o processo de recuperação atribuída a pessoa designada pelo juiz ou pelos credores;

- Previsão de reserva mínima de capital, sem a qual a empresa será automaticamente liquidada.

Note-se que todas as variáveis estão relacionadas a direito falimentar e que, nesse quadro, elas pressupõem a existência de dois procedimentos para lidar com situações de insolvência: o processo de recuperação e o de falência.

O índice de proteção dos direitos dos credores é calculado com base na verificação da existência de regras correspondentes a essas variáveis nos textos das leis de direito falimentar de cada país estudado. Como a quinta variável (previsão de reserva mínima de capital) é tomada como medida de reforço dos direitos dos credores, o índice varia de zero a quatro: a cada regra do direito de um país que corresponda a uma das quatro primeiras variáveis, é conferido um ponto. Caso não haja regra jurídica que corresponda à variável, não é conferido

Responsibility Research Center, Proxy Voting Guide. Washington: Investor Responsability Research Center, 1994/1995; VISHNY, P., Guide to International Commerce Law, New York: McGraw-Hill, 1994.

${ }^{88}$ La Porta et al, Law and Finance, 1998, e Legal Determinants of External Finance, 1997. 
nenhum ponto. Assim, na métrica dos direitos dos credores, zero é o menor nível de proteção dos direitos dos credores e quatro, o grau máximo.

Considerando que uma fraca proteção dos credores possa ser compensada pela eficiência dos mecanismos de enforcement do direito, La Porta et. al. avaliam também a qualidade do cumprimento da lei nos países estudados. Para tanto, valem-se de dados de agências privadas de avaliação de crédito. Eis as variáveis:

- Eficiência do sistema judicial: dados de 1980 a 1983, fornecidos pela Business International Corporation;

- Rule of Law: dados de 1982 a 1995, colhidos do guia International Country Risk;

- Nível de corrupção no governo: idem;

- Risco de expropriação pelo governo (confisco ou nacionalização forçada): idem;

- Risco de quebra de contratos pelo governo: idem.

Como os próprios La Porta et. al. admitem, apenas as duas primeiras variáveis dizem respeito ao cumprimento da lei. As demais tocam ao próprio ambiente de negócios e à segurança percebida pelas empresas. Tendo em conta não apenas essa limitação, mas também a ausência de informações sobre os recortes temporais adotados na coleta desses dados ${ }^{89}$ e o fato de o assunto ter sido retomado em um texto específico de três desses autores e de Djankov, este trabalho opta por não se ater a uma descrição mais detida dos critérios de avaliação do enforcement presentes neste texto.

O artigo Courts mede a qualidade do enforcement de contratos em 109 países. Os dados para essa mensuração são colhidos basicamente por meio de questionários respondidos por advogados de escritórios membros da Lex Mundi ou da Lex Africa, duas associações internacionais de bancas de advocacia. ${ }^{90}$

\footnotetext{
${ }^{89}$ Não é explicado por que o dado de eficiência do sistema judicial se refere ao período de 1980 a 1983 e os demais se referem ao período de 1982 a 1995. Também não é informado também por que o recorte temporal é diferente daquele usado para os dados de direitos dos credores.

${ }^{90}$ DJAnkov, S. et al. Courts, Quarterly Journal of Economics, n. 118, 2003, p. 459.
} 
Em cada país, os questionários são respondidos por dois advogados de um mesmo escritório. O primeiro, da área de contencioso, responde o questionário; e o segundo, da área de direito comercial, revisa as respostas. Devolvidos os questionários e tabulados os dados, os advogados podem ser chamados para esclarecer eventuais inconsistências em suas respostas.

Os questionários partem de dois casos hipotéticos: uma cobrança de cheque sem fundos e um despejo de inquilino por falta de pagamento. Supõe-se que tais casos sejam, ao mesmo tempo, simples o bastante para permitir a comparação internacional e adequadamente reveladores da qualidade do cumprimento de contratos em cada país pesquisado. Todas as questões devem ser respondidas como se os respondentes estivessem diante desses dois casos. O objetivo específico do questionário é colher dados para apurar: (a) o tempo de duração estimado para resolver os casos; e (b) o nível de formalidades exigidas pelo processo civil (ou administrativo, se a cobrança ou o despejo puder valer-se desse meio).

Os indicadores do nível de formalidade são construídos de acordo com um modelo teórico que considera ideal um sistema leigo de administração da justiça, pelo qual "a dispute between two neighbors can be resolved by a third on fairness grounds, with little knowledge or use of law, no lawyers, no written submissions, no procedural constraints on how evidence, witnesses, and arguments are presented, and no appeal." 91

Com base nesse modelo, Djankov et al. criam sete indicadores. O quadro abaixo lista sumariamente os indicadores e as características consideradas como próximas do ideal de justiça mencionado no parágrafo anterior:

\footnotetext{
${ }^{91}$ Djankov et al. Courts, 2003, p. 455. Tradução livre: "uma disputa entre dois vizinhos pode ser resolvida por um terceiro com base em princípios de justiça, mesmo que haja pouco conhecimento ou uso do direito, mesmo sem advogados, sem compromissos escritos, sem procedimentos processuais sobre provas, testemunhas, mesmo sem sustentações orais e recursos."
} 
Quadro 2 - Courts: Referências para a mensuração do nível de formalidade processual

\begin{tabular}{|c|c|}
\hline INDICADOR & IDEAL DE JUSTIÇA \\
\hline \multirow{3}{*}{$\begin{array}{l}\text { Grau de profissionalização demandado de } \\
\text { juízes e advogados }\end{array}$} & Há tribunais especializados \\
\hline & $\begin{array}{l}\text { Admite o julgamento por juízes leigos, não } \\
\text { necessariamente formados em direito }\end{array}$ \\
\hline & Dispensa a representação de advogados \\
\hline Procedimentos escritos e orais & Oralidade processual \\
\hline $\begin{array}{l}\text { Deveres de fundamentação na lei ou em } \\
\text { precedentes }\end{array}$ & $\begin{array}{l}\text { Partes e juízes não precisam fundamentar pedidos } \\
\text { e decisões em leis ou em precedentes }\end{array}$ \\
\hline \multirow{7}{*}{ Regime da prova } & $\begin{array}{l}\text { Juiz pode solicitar a produção de provas não } \\
\text { demandadas pelas partes }\end{array}$ \\
\hline & $\begin{array}{l}\text { Juiz pode dispensar provas que ele julgue } \\
\text { irrelevantes para o caso }\end{array}$ \\
\hline & Indícios são aceitos como provas \\
\hline & $\begin{array}{l}\text { Juiz deve prequalificar as questões antes que elas } \\
\text { sejam feitas à testemunha }\end{array}$ \\
\hline & $\begin{array}{c}\text { Somente são aceitos originais ou cópias } \\
\text { autenticadas de documentos }\end{array}$ \\
\hline & Lei não define valor da prova \\
\hline & Registro das provas não é mandatório \\
\hline \multirow{3}{*}{$\begin{array}{c}\text { Controle da instância superior sobre os atos da } \\
\text { primeira instância }\end{array}$} & $\begin{array}{l}\text { A execução não precisa aguardar o julgamento da } \\
\text { apelação }\end{array}$ \\
\hline & $\begin{array}{c}\text { Somente novos fatos ou questões de direito } \\
\text { ensejam apelação }\end{array}$ \\
\hline & Não é possível recorrer de decisões interlocutórias \\
\hline \multirow{3}{*}{$\begin{array}{l}\text { Formalidades que tornam as partes legalmente } \\
\text { atreladas ao processo e às suas consequências }\end{array}$} & $\begin{array}{l}\text { Processo é iniciado sem a obrigatoriedade de } \\
\text { conciliação ou mediação prévia }\end{array}$ \\
\hline & $\begin{array}{c}\text { Réu não precisa ser citado pessoalmente por } \\
\text { oficial de justiça }\end{array}$ \\
\hline & $\begin{array}{l}\text { As partes não precisam ser notificadas } \\
\text { pessoalmente do conteúdo da sentença }\end{array}$ \\
\hline $\begin{array}{l}\text { Quantidade de atos necessários para cobrar um } \\
\text { cheque sem fundos e para promover um } \\
\text { despejo por falta de pagamento }\end{array}$ & Quanto menor, melhor \\
\hline
\end{tabular}

Fonte: Elaboração própria, com base em Djankov et al. ${ }^{92}$

\footnotetext{
${ }^{92}$ Courts, 2003, p. 461-477.
} 
É considerada também a estrutura de incentivos para as partes envolvidas no processo. Assim, são avaliadas positivamente: ${ }^{93}$

- Em relação ao tribunal: a existência de prazos para deferir a petição inicial, para julgar a causa e para intimar as partes do conteúdo da sentença;

- Em relação às partes: a existência de prazos para apresentar provas e defesa;

- Em relação aos advogados: a proibição dos acordos de quota litis (honorários devidos em caso de sucesso na lide e calculados como um percentual do resultado obtido com o processo) e a existência da regra segundo a qual o perdedor pague as custas do processo.

Djankov et al. levam em conta, ainda, pesquisas de opinião sobre a qualidade do direito percebida por empresários, além de dados de avaliação do ambiente de negócios colhidos pela World Business Environment Survey. ${ }^{94}$

Como se pôde notar, o primeiro nível de análise da Law and Finance é marcado pelo emprego de métodos para a avaliação da qualidade do direito. Nessa empreitada, é considerado o conteúdo específico do direito de cada país examinado, que é comparado a variáveis construídas de acordo com o que se considera incentivador da decisão de investimento.

Os resultados obtidos mediante o emprego desses métodos conduzem ao segundo nível de análise da Law and Finance. Tanto na avaliação do grau de proteção aos credores como na apuração das condições de cumprimento de contratos, essa literatura aponta que os resultados não variam aleatoriamente de um país para outro. Variam, sim, conforme a tradição jurídica da qual deriva o direito de cada país.

Ou seja, nesse nível de análise, a Law and Finance vale-se da identificação de ênfases e limitações inerentes às tradições jurídicas para tentar explicar as diferenças internacionais no

\footnotetext{
${ }^{93}$ Djankov et al. Courts, 2003, p. 470.

${ }^{94}$ Djankov et al. Courts, 2003, p. 476-477.
} 
conteúdo de regras de proteção aos credores e no cumprimento de contratos. Conforme essa explicação, os sistemas de common law e de civil law apresentam prioridades diferentes em relação à proteção dos direitos de propriedade privada ante o Estado, bem como capacidades distintas de adaptação a demandas econômicas. ${ }^{95}$

Segundo a Law and Finance, são dois os mecanismos pelos quais a tradição jurídica influencia o desenvolvimento do direito: o mecanismo da adaptabilidade e o mecanismo político. Sustenta-se que a common law, por ser produto principalmente da jurisprudência (case law), tem maior capacidade de adaptar-se eficientemente às necessidades econômicas; e que os países de civil law, onde o processo de mudança jurídica é mais rígido, tendem a apresentar uma lacuna maior entre as demandas da economia e a capacidade do sistema jurídico de prover regras que fomentem o desenvolvimento financeiro. ${ }^{96}$ É dito que, em razão de a jurisprudência não ser reconhecida como fonte formal do direito nas jurisdições de civil law, a mudança jurídica sempre dependerá de revisões de códigos e leis, o que diminui sua capacidade de adaptação eficiente a novas demandas. ${ }^{97}$

Sobre o mecanismo político, afirma-se que a common law, especialmente por sua tradição de magistratura independente, tende a proteger melhor os direitos de propriedade privada em face do Estado. Já nos países de civil law, em que os juízes não contam com as mesmas condições de independência perante o legislativo e o executivo (estabilidade no cargo, poderes para rever a constitucionalidade de leis e de políticas governamentais etc.), a magistratura tende a amparar prioritariamente os direitos do Estado em detrimento dos direitos de propriedade privada. ${ }^{98}$ Como a proteção dos direitos de propriedade está na base do desenvolvimento financeiro, as diferenças na tradição jurídica poderiam explicar as diferenças nos níveis de desenvolvimento financeiro dos países. ${ }^{99}$

\footnotetext{
${ }^{95}$ Beck e Levine, Legal Institutions and Financial Development, 2005, p. 252.

${ }^{96}$ Beck e Levine, Legal Institutions and Financial Development, 2005, p. 261.

${ }^{97}$ Armour, Deakin, Sarkar, Siems e Singh, Shareholder Protection and Stock Market Development, 2007, p. 3-4.

${ }^{98}$ LA PORTA et al. Judicial Checks and Balances, Journal of Political Economy, v. 112 (2), 2004, p. 446; Beck e Levine, Legal Institutions and Financial Development, 2005, p. 260.

${ }^{99}$ Beck e Levine, Legal Institutions and Financial Development, 2005, p. 260.
} 
Como se pode depreender dos mecanismos usados pela Law and Finance para explicar as diferenças nos níveis de proteção dos credores entre países de common law e de civil law, a criação do direito pelo poder judiciário é tomada como constitutiva do direito. Por outro lado, ao pressupor que os países de civil law contam com uma rígida divisão entre os momentos de criação e de aplicação do direito, essa leitura pode dar azo a interpretações que valorem negativamente qualquer instância de discricionariedade de um juiz da civil law, ainda que se trate da mera fixação de sentido de um princípio. Essa leitura é feita no Brasil, por exemplo, em alguns textos que dialogam com a literatura da Law and Finance. ${ }^{100}$ Assim, dependendo do contexo, a discricionariedade judicial pode ser tomada como positiva (países de common law) ou como negativa (países de civil law), uma vez que se entende que na common law ela é parte do sistema e o constitui, enquanto que na civil law pode representar um risco à lógica implementada por uma lei ou por um código.

Em suma, ao associar o primeiro e segundo níveis de análise, a Law and Finance conclui que os países de common law são mais aptos que os de civil law para prover regras jurídicas propulsoras do desenvolvimento. ${ }^{101}$ Dentre os países de civil law, são mais eficientes na indução do crescimento econômico os de origem escandinava e germânica; no final da escala decrescente de eficiência estão os países de civil law francesa. ${ }^{102}$

Como este trabalho centra-se na discussão de um momento do direito brasileiro e não pretende compará-lo com experiências jurídicas de outros países, ele priorizará as contribuições do primeiro nível de análise da Law and Finance para a construção da perspectiva da dotação institucional delineada acima. Portanto, não será explorado aqui o argumento das tradições jurídicas, apenas serão apresentadas as instituições tidas por essa literatura como relevantes para o desenvolvimento do mercado de crédito.

\footnotetext{
${ }^{100}$ A esse respeito, cf. PINHEIRO, A. C. O componente judicial dos spreads bancários. In: BCB. Economia bancária e crédito. 2003. p. 34-43; PINHEIRO, A. C. Economia e justiça: conceitos e evidência empírica. 2001. Disponível em: www.ifb.com.br/download.php?tindex=estudos\&id=14. Acesso em 15 dez. 2008. FACHADA, P.; Figueiredo, L. F.; LundBerg, E. Sistema judicial e mercado de crédito no Brasil. Nota Técnica n. 35. Brasília: Banco Central do Brasil, 2003. Disponível em: http://www.bcb.gov.br/pec/NotasTecnicas/Port/2003nt35sistemajudicialmercadocredbrasilp.pdf. SADDI, J. Crédito e Judiciário no Brasil: uma análise de Direito \& Economia. São Paulo: Quartier Latin, 2007. Parte 2. ${ }^{101}$ Shareholder Protection and Stock Market Development, 2007, p. 3.

${ }^{102}$ La Porta et al, Law and Finance, 1998, e La Porta et al, Legal Determinants of External Finance, 1997.
} 
Desde a criação do projeto Doing Business pelo Grupo de Desenvolvimento do Setor Privado do Banco Mundial (BM), ${ }^{103}$ a literatura da Law and Finance passou a desempenhar papel de destaque no campo prático das reformas jurídicas, já que seus métodos de mensuração da qualidade do direito foram adotados para embasar pesquisas comparativas sobre ambiente de negócios nos países membros do Banco Mundial. ${ }^{104}$ Eles passaram a influenciar, assim, decisões de investimento de atores privados e do próprio BM. ${ }^{105} \mathrm{Com}$ isso, as regras valorizadas como indutoras do desenvolvimento financeiro passaram a ser tomadas como referência por reformadores nacionais que pretendiam criar melhores condições para o investimento privado, especialmente por aqueles que demandavam recursos do Banco Mundial para a implementação dessas reformas. Recentemente, isso vem sendo reforçado pelo fato de que outras áreas do BM passaram a adotar os indicadores do projeto Doing Business para avaliar o impacto de reformas financiadas pelo Banco Mundial. ${ }^{106}$ Muito bem organizado, o website do projeto traz, inclusive, um simulador de reformas. Os interessados podem ensaiar como reformas específicas modificariam a posição relativa dos países no ranking de melhor clima para o investimento. ${ }^{107}$

No Banco Mundial, registre-se, o responsável pelo projeto Doing Business é Simeon Djankov, coautor de inúmeros trabalhos da Law and Finance. ${ }^{108}$ Os trabalhos que fornecem a base metodológica para as avaliações feitas por esse projeto são:

\section{Quadro 3 - Base metodológica do Projeto Doing Business (2004-2006)}

\footnotetext{
103 O projeto foi criado em 2003 e o primeiro relatório foi publicado em 2004. Dentro do Grupo de Desenvolvimento do Setor Privado, uma das vice-presidências do Banco Mundial, o projeto é desenvolvido pela Unidade de Resposta Rápida (Rapid Response Unit). A respeito, cf. www.doingbusiness.org e SANTOS, A. The World Bank's Uses of the "Rule of Law" Promise in Economic Development. In: TRUBEK, D.; SANTOS, A. (eds.) The New Law and Economic Development: A Critical Appraisal. Nova York: Cambridge University, 2006, p. 253-300.

${ }^{104}$ Cf. Quadro 3.

${ }^{105}$ Milhaupt e Pistor, Law and Capitalism, 2008, p. 20, nota 10, e p. 226.

${ }^{106}$ Santos, The World Bank's Uses of the "Rule of Law” Promise in Economic Development, 2006, p. 292.

${ }^{107} \mathrm{Cf}$. em www.doingbusiness.org.

${ }^{108}$ Santos, The World Bank's Uses of the "Rule of Law" Promise in Economic Development, 2006, p. 280, nota 90.
} 


\begin{tabular}{|c|c|c|}
\hline TEMA & ANO & TRABALHO \\
\hline \multirow{5}{*}{$\begin{array}{l}\text { Proteção dos direitos } \\
\text { dos credores }\end{array}$} & \multirow{2}{*}{2004} & $\begin{array}{l}\text { Djankov, McLiesh e Shleifer. Remedies in Credit Markets. Working } \\
\text { paper, Department of Economics, Harvard University, } 2003 .\end{array}$ \\
\hline & & $\begin{array}{l}\text { La Porta, Lopez-de-Silanes, Shleifer e Vishny. Law and Finance. } \\
\text { Journal of Political Economy, 106, p. 1113-55, } 1998 .\end{array}$ \\
\hline & \multirow{2}{*}{2005} & $\begin{array}{l}\text { Djankov, McLiesh e Shleifer. Private Credit Around the World. } \\
\text { Working paper, Department of Economics, Harvard University, } \\
2004 .\end{array}$ \\
\hline & & $\begin{array}{l}\text { La Porta, Lopez-de-Silanes, Shleifer e Vishny. Law and Finance. } \\
\text { Journal of Political Economy, 106, p. 1113-55, } 1998 .\end{array}$ \\
\hline & 2006 & $\begin{array}{l}\text { Djankov, McLiesh Shleifer. Private Credit in } 129 \text { Countries. } \\
\text { National Bureau of Economic Research Working Paper 11078, } 2005 .\end{array}$ \\
\hline $\begin{array}{l}\text { Cumprimento de } \\
\text { contratos }\end{array}$ & $\begin{array}{c}2004 \mathrm{a} \\
2006\end{array}$ & $\begin{array}{l}\text { Djankov, La Porta, Lopez-de-Silanes e Shleifer. Courts. Quarterly } \\
\text { Journal of Economics, 118, p. 453-517, } 2003 .\end{array}$ \\
\hline
\end{tabular}

Fonte: Banco Mundial

\subsubsection{Categorias de análise}

Especificamente para a análise das medidas de reforma do mercado de crédito selecionadas conforme os critérios expostos no item 1.2, esta pesquisa valer-se-á de categorias construídas com base nas referências mencionadas nos itens anteriores. Todas elas dizem respeito a características dos sistemas jurídicos valorizados pela Nova Economia Institucional, pelas visões de North e da Law and Finance. Como esse trabalho centra-se na discussão de um momento do direito brasileiro e não pretende compará-lo com experiências jurídicas de outros países, as categorias não tocam o argumento das tradições jurídicas.

Serão consideradas duas dimensões de análise, uma que diz respeito à previsibilidade de comportamentos, outra atinente à celeridade procedimental. Como a referência é sempre o credor, as categorias da dimensão previsibilidade estão focadas no comportamento tanto do devedor quanto do juiz, que é o terceiro responsável por resolver disputas entre os dois primeiros. Em relação ao comportamento do devedor, serão investigadas, no texto das

\footnotetext{
${ }^{109}$ DoING Business 2004, p. 112; DoING Business 2005, p. 85 e DoING Business 2006, p. 84.

${ }^{110}$ Doing Business 2004, p. 110; Doing Business 2005, p. 86 e Doing Business 2006, p. 88. Segundo informação prestada por e-mail pelo Banco Mundial, Remedies in Credit Markets e Private Credit Around the World são versões preliminares do paper Private Credit in 129 Countries.
} 
medidas de reforma do mercado de crédito, a existência de providências para minimizar o risco moral e as possibilidades de comportamento oportunista. ${ }^{111}$ Em relação ao juiz, a análise investigará se as medidas de reforma do mercado do crédito buscam diminuir o espaço de discricionariedade judicial, mediante o emprego de soluções inequívocas dadas por lei. ${ }^{112}$

Na dimensão da previsibilidade, o foco estará voltado para o regime jurídico das garantias e para o processo judicial. Em ambos os casos, examinar-se-á se as reformas buscam responder a preocupações com a agilidade de procedimentos: seja na cobrança de débitos, ${ }^{113}$ seja na constituição e realização de garantias contratuais. ${ }^{114}$ Quando for o caso, as medidas serão associadas a variáveis específicas valorizadas pela literatura da Law and Finance.

Quadro 4 - Proteção dos interesses do credor: categorias de análise

\begin{tabular}{|c|c|c|}
\hline \multirow{2}{*}{ DIMENSÕES } & FOCO & OBJETIVOS ESPECÍFICOS \\
\hline \multirow{1}{*}{ Previsibilidade } & $\begin{array}{c}\text { Comportamento } \\
\text { do devedor }\end{array}$ & $\begin{array}{c}\text { Minimizar risco moral e possibilidades de comportamentos oportunistas (reforma de } \\
\text { procedimentos e punição de atos de má-fé) }\end{array}$ \\
\cline { 2 - 4 } & $\begin{array}{c}\text { Comportamento } \\
\text { do juiz }\end{array}$ & $\begin{array}{c}\text { Diminuição da discricionariedade judicial } \\
\text { Soluções inequívocas dadas por lei }\end{array}$ \\
\hline Celeridade & $\begin{array}{c}\text { Sistema de } \\
\text { garantias }\end{array}$ & $\begin{array}{c}\text { Agilidade na constituição e na realização das garantias: medidas que aumentam o } \\
\text { garantias reais; gestão da empresa não permanece com o devedor; não-congelamento } \\
\text { automático dos ativos; restrições para entrar em recuperação, como o consentimento } \\
\text { dos credores) e fora dos casos de insolvência (descrição genérica dos ativos que } \\
\text { servem de garantia; possibilidade de qualquer pessoa conceder ou receber garantias } \\
\text { relativas à propriedade; possibilidade de credores tomarem posse das garantias e } \\
\text { vendê-las sem recorrer aos tribunais; descrição genérica dos débitos em contratos com } \\
\text { garantia; registro unificado de garantias, que inclui ônus sobre bens móveis; } \\
\text { prioridade dos credores com garantias em casos fora da falência) }\end{array}$ \\
\cline { 2 - 4 } & $\begin{array}{c}\text { Processo judicial } \\
\text { Agilidade na cobrança judicial de débitos: diminuição do número de procedimentos, } \\
\text { do tempo, e das formalidades para cobrança de dívidas }\end{array}$ \\
\hline
\end{tabular}

Fonte: Elaboração própria. ${ }^{115}$

${ }^{111}$ Cf. seção 1.3.2.

${ }^{112}$ Cf. seção 1.3.3.

${ }^{113}$ Idem.

${ }^{114}$ La Porta et al, Law and Finance, 1998. Os exemplos de regras que conferem agilidade à constituição e à realização de garantias foram retirados de Doing Business 2005, p. 85. Nesse relatório do projeto Doing Business, as centrais de informação de crédito também são consideradas como relevantes na proteção aos credores. Porém, como as medidas sugeridas pelo Governo relacionadas a esse assunto não foram implementadas, os critérios não foram aqui explorados.

115 Fontes: North, Institutions, Institutional Change, and Economic Performance, 1990; Beck e Levine, Legal Institutions and Financial Development, 2005; La Porta et al, Law and Finance, 1998; Djankov et al., Courts, 2003; e Doing Business, 2005. 


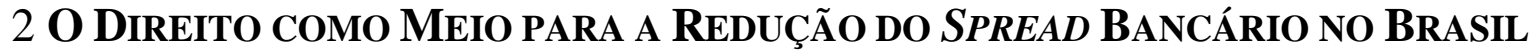

O objetivo deste capítulo é descrever e analisar as medidas de reforma dos sistemas de insolvência e de cobrança de dívidas propostas pelo Banco Central do Brasil nos relatórios anuais do Projeto Juros e Spread Bancário (PJSB), publicados de 1999 a 2006, e pela Secretaria de Política Econômica do Ministério da Fazenda no documento Reformas microeconômicas e crescimento de longo prazo (RMCLP), publicado em 2004.

A cada medida é dedicada uma seção, e cada seção está dividida em duas partes. A primeira delas apresenta o contexto em que surgem as medidas. A segunda parte dedica-se a analisar os argumentos apresentados pelo Banco Central do Brasil e pela Secretaria de Política Econômica na justificativa da medida a implementar ou na avaliação da medida implementada.

O quadro que segue lista as medidas analisadas e dá notícia dos instrumentos empregados pelo Poder Executivo para implementá-las (edição de medida provisória ou iniciativa de projeto de lei). 
Quadro 5 - Medidas propostas e desdobramentos

\begin{tabular}{|c|c|c|c|}
\hline \multicolumn{2}{|c|}{ MEDIDA PROPOSTA } & IMPLEMENTAÇÃO & DESDOBRAMENTOS \\
\hline \multirow{4}{*}{\multicolumn{2}{|c|}{ Criação da cédula de crédito bancário }} & MPV 1.925, de 14/10/1999 & $\begin{array}{c}\text { Reeditada } 15 \text { vezes. Revogada pela MPV } \\
2.065 / 2000 .\end{array}$ \\
\hline & & MPV 2.065-16, de 27/12/2000 & $\begin{array}{c}\text { Reeditada seis vezes. Revogada pela MPV } \\
2.160-23 .\end{array}$ \\
\hline & & MPV 2.160-23, de 28/06/2001 & $\begin{array}{l}\text { Reeditada duas vezes. Revogada pela Lei } \\
10.931 \text {, de } 02 / 08 / 2004 \text {. }\end{array}$ \\
\hline & & PL 3.065, de 08/03/2004 & $\begin{array}{c}\text { Na Câmara dos Deputados, em } 09 / 03 / 2004 \text {, foi } \\
\text { apensado ao PL } 2.109 / 1999 \text {. Transformado na } \\
\text { Lei } 10.931 \text {, de } 02 / 08 / 2004 \text {. }\end{array}$ \\
\hline \multirow{4}{*}{\multicolumn{2}{|c|}{$\begin{array}{l}\text { Aumento do alcance da alienação e da } \\
\text { cessão fiduciárias }\end{array}$}} & MPV 1.925, de 14/10/1999 & $\begin{array}{c}\text { Reeditada } 15 \text { vezes. Revogada pela MPV } \\
2.065 / 2000 .\end{array}$ \\
\hline & & MPV 2.065-16, de 27/12/2000 & $\begin{array}{c}\text { Reeditada seis vezes. Revogada pela MPV } \\
2.160-23 .\end{array}$ \\
\hline & & MPV 2.160-23, de 28/06/2001 & $\begin{array}{l}\text { Reeditada duas vezes. Revogada pela Lei } \\
10.931 \text {, de } 02 / 08 / 2004 \text {. }\end{array}$ \\
\hline & & PL 3.065 , de 08/03/2004 & $\begin{array}{c}\text { Na Câmara dos Deputados, em 09/03/2004, foi } \\
\text { apensado ao PL } 2.109 / 1999 \text {. Transformado na } \\
\text { Lei } 10.931 \text {, de } 02 / 08 / 2004 \text {. }\end{array}$ \\
\hline \multirow{5}{*}{ 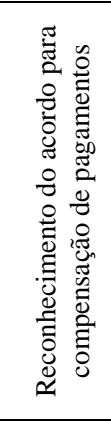 } & \multirow{3}{*}{$\begin{array}{l}\text { Sistema de Pagamentos } \\
\text { Brasileiro }\end{array}$} & MPV 2.008, de 14/12/1999 & $\begin{array}{l}\text { Reeditada seis vezes. Revogada pela MPV } \\
2.040 / 2000 .\end{array}$ \\
\hline & & MPV 2.040 , de 28/06/2000 & $\begin{array}{l}\text { Reeditada seis vezes. Revogada pela MPV } \\
2.115 / 2001 .\end{array}$ \\
\hline & & MPV 2.115 , de 27/12/2000 & $\begin{array}{l}\text { Reeditada duas vezes. Transformada na Lei } \\
10.214 \text {, de } 27 / 03 / 2001 \text {. }\end{array}$ \\
\hline & Mercado de balcão & MPV 2.139-67, de 22/06/2001 & $\begin{array}{l}\text { Reeditada duas vezes. Revogada pela MPV } \\
\qquad 2.192-68 / 2001 \text {. }\end{array}$ \\
\hline & & MPV 2.1926-68, de 28/06/2001 & $\begin{array}{c}\text { Reeditada duas vezes. Continua em vigor por } \\
\text { força da EC } 32 .\end{array}$ \\
\hline \multicolumn{2}{|c|}{$\begin{array}{l}\text { Previsão legal do crédito consignado em } \\
\text { folha de pagamento }\end{array}$} & MPV 130, 17/09/2003 & Convertida na Lei 10.820, de 17/12/2003. \\
\hline \multicolumn{2}{|c|}{ Reforma da Lei de Falências } & PL 4.376 , de 22/12/1993 & Transformado na Lei 11.101, de 09/02/2005. \\
\hline \multirow{6}{*}{ 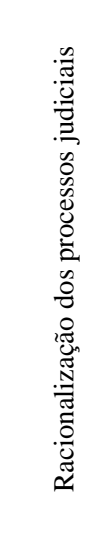 } & Súmula vinculante & EC 32, de 11/09/2001 & - \\
\hline & $\begin{array}{l}\text { Recursos: agravo retido e } \\
\text { agravo de instrumento }\end{array}$ & PL 4.727 , de $27 / 12 / 2004$ & Transformado na Lei 11.187, de 19/10/2005. \\
\hline & $\begin{array}{c}\text { Execução de títulos } \\
\text { executivos judiciais } \\
\text { (cumprimento de sentença) }\end{array}$ & PL 3.253 , de 29/03/2004 & Transformado na Lei 11.232, de 22/12/2005. \\
\hline & $\begin{array}{c}\text { Recursos: forma de } \\
\text { interposição, saneamento } \\
\text { de nulidades e recebimento } \\
\text { da apelação }\end{array}$ & PL 4.724 , de $27 / 12 / 2004$ & Transformado na Lei 11.276 , de 07/02/2006. \\
\hline & $\begin{array}{l}\text { Julgamento de processos } \\
\text { repetitivos }\end{array}$ & PL 4.728 , de $27 / 12 / 2004$ & Transformado na Lei 11.277 , de 07/02/2006. \\
\hline & $\begin{array}{l}\text { Execução dos títulos } \\
\text { executivos extrajudiciais }\end{array}$ & PL 4.497, de $19 / 11 / 2004$ & Transformado na Lei 11.382, de 06/12/2006. \\
\hline
\end{tabular}

Fonte: Elaboração própria. ${ }^{116}$

${ }^{116}$ Com base em: Diário da Câmara dos Deputados, Diário do Senado Federal, Diário do Congresso Nacional, Diário Oficial da União, Sileg (sistema de acompanhamento de lei e outras proposições em tramitação na Câmara 
O quadro que segue distribui as medidas no tempo, considerando os documentos em que aparecem. Interessa notar que há medidas que, presentes no governo Fernando Henrique Carodos, se mantiveram no governo Lula, a despeito das alterações de contexto e da variação no tempo.

\section{Quadro 6 - Medidas por documento}

\begin{tabular}{|c|c|c|c|c|c|c|c|c|c|}
\hline MEDIDAS & $\begin{array}{l}\frac{\partial}{\alpha} \\
\frac{\alpha}{2} \\
\frac{0}{2}\end{array}$ & 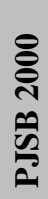 & 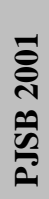 & 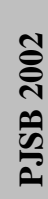 & 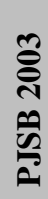 & 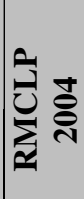 & 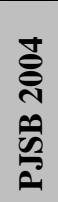 & 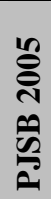 & 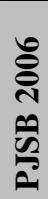 \\
\hline Criação da cédula de crédito bancário & $\sqrt{ }$ & $\sqrt{ }$ & $\sqrt{ }$ & $\sqrt{ }$ & $\sqrt{ }$ & & $\sqrt{ }$ & $\sqrt{ }$ & \\
\hline $\begin{array}{l}\text { Aumento do alcance da alienação e da cessão } \\
\text { fiduciárias }\end{array}$ & & $\sqrt{ }$ & $\sqrt{ }$ & $\sqrt{ }$ & $\sqrt{ }$ & & $\sqrt{ }$ & $\sqrt{ }$ & \\
\hline $\begin{array}{c}\text { Reconhecimento do acordo para compensação } \\
\text { de pagamentos [SPB] }\end{array}$ & $\sqrt{ }$ & $\sqrt{ }$ & $\sqrt{ }$ & $\sqrt{ }$ & & & & & \\
\hline $\begin{array}{l}\text { Reconhecimento do acordo para compensação } \\
\text { de pagamentos [mercado de balcão] }\end{array}$ & & $\sqrt{ }$ & $\sqrt{ }$ & $\sqrt{ }$ & $\sqrt{ }$ & & $\sqrt{ }$ & $\sqrt{ }$ & \\
\hline $\begin{array}{l}\text { Previsão legal do crédito consignado em folha } \\
\text { de pagamento }\end{array}$ & & & & & $\sqrt{ }$ & & $\sqrt{ }$ & $\sqrt{ }$ & \\
\hline Reforma da Lei de Falências & $\sqrt{ }$ & $\sqrt{ }$ & $\sqrt{ }$ & $\sqrt{ }$ & $\sqrt{ }$ & $\sqrt{ }$ & $\sqrt{ }$ & $\sqrt{ }$ & \\
\hline Racionalização dos processos judiciais & & & & & $\sqrt{ }$ & & $\sqrt{ }$ & $\sqrt{ }$ & \\
\hline
\end{tabular}

Fonte: Elaboração própria, com base nos relatórios do PJSP e RMCLP.

Ao comentar o contexto de surgimento das medidas e o escopo de que se revestem, pretende-se testar a hipótese de que as sugestões de reforma propostas por esses documentos enxergam o direito na perspectiva da dotação institucional.

dos Deputados: http://www.camara.gov.br/sileg) e informações prestadas pela Secretaria de Assuntos Legislativos do Ministério da Justiça. 


\subsection{Criação da cédula de crédito bancário}

\subsubsection{Contexto}

Visto como técnica de solução de conflitos, o direito processual civil pode ser definido como um conjunto de instrumentos voltados para debelar crises jurídicas, situações de insatisfação levadas a juízo. ${ }^{117}$ Segundo Dinamarco, o direito processual civil prevê tutela para três tipos de crises jurídicas: crise de certeza, crise de adimplemento e crise de situações jurídicas. ${ }^{118}$ Nessa subseção interessa uma especificamente, a crise de adimplemento.

Há crise de adimplemento quando uma pessoa alega ter um direito não satisfeito por outra, que deveria adimplir uma obrigação e não o fez. ${ }^{119}$ Tendo em conta a lei processual vigente à época em que foi proposta a criação da cédula de crédito bancário, ${ }^{120}$ um alegado credor não satisfeito talvez tivesse de valer-se de dois processos judiciais distintos para debelar uma crise de adimplemento: do processo de conhecimento e do processo de execução. O processo de conhecimento serviria para declarar qual das partes do processo (o autor, alegado credor, ou o réu, alegado devedor) estava com a razão. Caso fosse julgado procedente o pedido do autor (sentença condenatória) e o réu condenado não cumprisse voluntariamente o comando da sentença, o credor não satisfeito poderia valer-se do processo de execução. Nesse caso, a sentença condenatória proferida no processo de conhecimento serviria de título executivo, requisito para iniciar o processo de execução. ${ }^{121}$ No processo de execução, poderiam ser usados os meios de execução forçada para a satisfação do direito reconhecido no processo de conhecimento. Em suma, processo de conhecimento e processo de execução conjugados - eram a via ordinária para contornar as crises de adimplemento.

\footnotetext{
${ }^{117}$ Dinamarco, C. Instituições de Direito Processual Civil. São Paulo: Malheiros, 2005. v. 1. Sobre as crises jurídicas e as tutelas específicas, p. 168. Sobre a definição do processo civil como técnica, p. 156. Lá também são discutidos os escopos sociais, políticos e jurídicos do processo.

${ }^{118}$ Sobre as demais crises jurídicas e sobre as tutelas específicas para contorná-las, cf. Dinamarco, Instituições de Direito Processual Civil, 2005, p. 168 e seguintes.

${ }^{119}$ Dinamarco, Instituições de Direito Processual Civil, 2005, p. 168-169.

${ }^{120}$ Em 2005, a Lei 11.232 alterou o CPC: a execução por título executivo judicial, que era um processo autônomo, passou a ser uma fase de cumprimento de sentença. A respeito, cf. o item 2.6.1.

${ }^{121}$ CPC, artigo 580.
} 
Em casos específicos, contudo, a lei processual permite (já permitia à época e continua a permitir) que o credor de obrigação certa, líquida e exigível salte o processo de conhecimento e ingresse em juízo já no processo de execução. ${ }^{122} \mathrm{O}$ acesso direto à via executiva traz ganhos em termos de tempo e de previsibilidade, pois o credor não precisa passar pela fase de instrução probatória para convencer o juiz de que tem razão, nem pelos dois procedimentos de citação pessoal (um para iniciar o processo de conhecimento, outro para desencadear a execução). Para tanto, o credor deve estar munido de um documento legalmente reconhecido como título executivo extrajudicial.

Essa via de acesso direto ao processo de execução vinha sendo usada por instituições financeiras para reaver, de clientes inadimplentes, valores emprestados em sistema de crédito rotativo, mediante contratos de abertura de crédito. Esses contratos - formalizados nos termos prescritos pelo Código de Processo Civil (CPC), artigo 585, inciso II, $2^{\mathrm{a}}$ parte, ${ }^{123} \mathrm{e}$ acompanhados do extrato da conta corrente e da especificação do crédito - eram apresentados em juízo como títulos executivos extrajudiciais. A posição do Poder Judiciário em relação à admissibilidade desse acesso direto não se mostrou, contudo, uniforme. Ora eram aceitos como tais pelos tribunais, prosseguindo-se a execução, ora eram rejeitados, indicando-se a necessidade de um prévio processo de conhecimento. A justificativa para negar-se o acesso direto ao processo execução era a falta de certeza em relação à quantia a ser executada, já que o extrato da conta corrente e a especificação do crédito eram documentos produzidos unilateralmente pelo alegado credor, sem a participação do dito devedor.

A orientação do Superior Tribunal de Justiça (STJ) sobre o assunto foi consolidada no julgamento dos Embargos de Divergência no Recurso Especial 108.259/RS, realizado em 13/12/1998 e publicado no Diário Oficial da Justiça em 20/09/1999:

[...] mesmo subscrito por quem é indicado em débito e assinado por duas testemunhas, o contrato de abertura de crédito não é título executivo, ainda que a execução seja instruída com extrato e que os lançamentos fiquem devidamente esclarecidos, com a explicitação dos cálculos, dos índices e dos critérios adotados para definição do

\footnotetext{
${ }^{122}$ A respeito, cf. CPC, artigo 585.

${ }^{123} \mathrm{O}$ artigo 585 do CPC arrola os títulos executivos extrajudiciais. A segunda parte do inciso II considera título executivo extrajudicial "o documento particular assinado pelo devedor e por duas testemunhas".
} 
débito, pois esses são documentos unilaterais de cuja formação não participou o eventual devedor. $^{124}$

Essa linha de decisão foi reiterada pelo STJ em vários julgamentos posteriores ${ }^{125} \mathrm{e}$ levou à edição da Súmula 233, que determinou: "O contrato de abertura de crédito, ainda que acompanhado de extrato da conta-corrente, não é título executivo."126

Quando o tema foi sumulado pelo STJ, em 13/12/1999, o assunto já havia sido tratado pela Medida Provisória 1.925, editada pela primeira vez em 14/10/1999. Essa MPV autorizou pessoas físicas ou jurídicas a emitirem cédulas de crédito bancário, como promessa de pagamento em dinheiro, em favor de instituições financeiras. ${ }^{127} \mathrm{E}$, a exemplo de outras cédulas de crédito, conferiu executividade a esse título:

Art. $3^{\circ}$. A Cédula de Crédito Bancário é título executivo extrajudicial e representa dívida em dinheiro certa, líquida e exigível, seja pela soma nela indicada, seja pelo saldo devedor demonstrado em planilha de cálculo, ou nos extratos de conta-corrente $[\ldots]$

Na verdade, a MPV 1.925 acabou por conferir força executiva não somente aos títulos emitidos com base em contratos de abertura de crédito, mas, no limite, a toda promessa de pagamento em dinheiro feita a instituição financeira em operações de crédito, "de qualquer modalidade", como ressalta o próprio texto do artigo $1^{\circ} .^{128}$ A cédula de crédito bancário poderia ser emitida, assim, em razão de contratos de empréstimo ou de mútuo, desde que assinados com instituições financeiras. ${ }^{129}$ Essa MPV foi reeditada várias vezes e, em

\footnotetext{
124 Trecho da ementa. Inteiro teor do acórdão disponível em www.stj.gov.br. Sobre a consolidação do entendimento do STJ, confira o voto do ministro Ruy Rosado de Aguiar, relator dos Embargos de Divergência no Recurso Especial 148.290/RS, p. 1. Humberto Theodoro Junior afirma que a "uniformização" se deu com o 148.290, mas essa decisão apenas atesta a consolidação já verificada no 108.259/RS.

${ }^{125}$ REsp 121.721-SC (decisão de 18/03/1999, publicada no Diário Oficial da Justiça em 10/05/1999, p. 177), REsp 97.816-MG (decisão de 11/02/1999, publicada no Diário Oficial da Justiça em 10/05/1999, p. 176), EREsp 148.290-RS (decisão em 24/02/1999, publicada no Diário Oficial da Justiça em 03/05/1999, p. 91). ${ }^{126}$ STJ, Súmula 233, de 13/12/1999, publicada no Diário Oficial da Justiça em 08/02/2000, p. 264.

${ }^{127}$ MPV 1.925, artigo $1^{\circ}$.

${ }^{128}$ MPV 1.925, artigo $1^{\circ}$. Humberto Theodoro Jr. argumenta que essa ampliação de escopo é prova de que a ação do executivo, ao editar a MP, não foi uma tentativa de contornar o assentamento da questão na jurisprudência do STJ. Cf. THEODORO JunIOR, H. A cédula de crédito bancário como título executivo extrajudicial no direito brasileiro. Academia Brasileira de Direito Processual, p. 10. Disponível em: www.abdpc.org.br/artigos/artigo48.htm. Acesso em 15 dez. 2008.

${ }^{129}$ RizZARDO, A. Contratos de crédito bancário, 6. ed. São Paulo: Revista dos Tribunais, 2003. p. 303.
} 
02/08/2004, foi revogada pela Lei 10.931 , que previu a mesma disciplina para as cédulas de crédito bancário.

\subsubsection{Lógica de intervenção}

Nos documentos oficiais que são objeto desta pesquisa, a criação da cédula de crédito bancário é associada a duas grandes vantagens: simplicidade e eficácia. A simplicidade decorre das facilidades de constituição de uma cédula de crédito bancário e da possibilidade de registro das garantias no próprio título. A eficácia diz respeito às formas de garantias aceitas e aos meios disponíveis para se fazer valer o disposto na cédula.

Tendo como parâmetro as categorias desenvolvidas no capítulo 1, essas vantagens podem ser interpretadas como ganhos no nível de proteção dos credores, nas dimensões da previsibilidade e da celeridade.

Parte dessas virtudes identificadas na cédula de crédito bancário decorre de a lei ter-lhe conferido o status de título executivo, que garante ao credor insatisfeito o acesso direto à via executiva do processo civil. Em outras palavras: diante do inadimplemento do devedor, o credor pode valer-se do Poder Judiciário para empregar os meios de execução forçada, sem ter de discutir num processo prévio a relação jurídica que baseou a emissão da cédula de crédito bancário. Com isso, são superados dois obstáculos: a instrução probatória, que caracteriza o processo de conhecimento, e a necessidade daquilo que seria a primeira de duas citações, uma para instalar o processo de conhecimento, outra para instalar o processo de execução. $\mathrm{O}$ credor ganha, assim, em previsibilidade e em celeridade.

Ao referir-se aos títulos de crédito, diz relatório de 1999 do PJSB:

\footnotetext{
A legislação brasileira admite dois regimes para efeito de execução judicial de dívidas. No âmbito civil, os contratos dependem de prova, o que demanda uma fase de conhecimento, que têm demorado até 4 anos, dado o congestionamento de processos no Judiciário. Com a utilização de títulos de crédito, típicos do direito comercial, a
} 
execução judicial independe de prova e da longa demora da fase de conhecimento, o que permitiria reaver créditos em prazos bem mais curtos. ${ }^{130}$

O fato de ser autônoma em relação à obrigação que enseja a sua emissão garante outra vantagem para a cédula de crédito bancário: a possibilidade de negociação dos títulos, que são exigíveis por si só. O excerto que segue, extraído do RMCLP, menciona essa qualidade e a associa à previsibilidade:

\begin{abstract}
A CCB é um título representativo do crédito bancário, de emissão do próprio tomador do crédito em favor da instituição financeira que o concede. Esse instrumento facilita a negociação da carteira de crédito dos bancos, tornando mais ágil a sua execução em caso de inadimplência do tomador. Com isso, eleva-se a segurança jurídica das operações de crédito, com implicações diretas sobre a redução de seu custo e elevação de seu volume no mercado primário de crédito bancário. A redução do risco da carteira de crédito do banco, o menor custo de execução judicial e um custo de oportunidade mais baixo na concessão do crédito - uma vez que a CCB facilita o banco negociar o crédito no mercado secundário - são os principais benefícios trazidos por esse novo instrumento. ${ }^{131}$
\end{abstract}

Por serem passíveis de registro na CETIP, ${ }^{132}$ são ampliadas as possibilidades de negociação desses títulos no mercado de balcão; ao permitir a emissão de certificados de cédulas de crédito bancário (documentos representativos de cédulas de crédito bancário mantidas em depósito pela instituição financeira), a Lei 10.931 também possibilita a constituição de um mercado secundário para a negociação das cédulas. ${ }^{133}$

O regime legal previsto para as cédulas de crédito bancário, além de ter ampliado o rol de garantias admissíveis ${ }^{134}$ (admite, inclusive, que a obrigação seja garantida por bem futuro), permite que o registro das garantias seja feito na própria cédula. Dessa forma, para fins de registro, os cartórios de imóveis têm aceitado a cédula de crédito bancário com a hipoteca

\footnotetext{
${ }^{130} \mathrm{BCB}$, Juros e spread bancário no Brasil, 1999, p. 26.

${ }^{131} \mathrm{SPE} / \mathrm{MF}$, Reformas microeconômicas e crescimento de longo prazo, p. 42.

132 A CETIP (antiga Câmara de Custódia e Liquidação e, desde 2008, CETIP S.A. - Balcão Organizado de Ativos e Derivativos), integrante do Sistema de Pagamentos Brasileiro (SPB), funciona como câmara de custódia escritural de ativos e de contratos e oferece um ambiente para negociações eletrônicas de títulos e valores mobiliários de renda fixa. Mais informações sobre a CETIP disponíveis em http://www.cetip.com.br. A respeito do SPB, confira nota 161 .

${ }^{133}$ Lei 10.931 , artigo 43 .

${ }^{134}$ Lei 10.931, artigo 31: “A garantia da Cédula de Crédito Bancário poderá ser fidejussória ou real, neste último caso, constituída por bem patrimonial de qualquer espécie, disponível e alienável, móvel ou imóvel, material ou imaterial, presente ou futuro, fungível ou infungível, consumível ou não, cuja titularidade pertença ao próprio emitente ou a terceiro garantidor da obrigação principal."
} 
cedularmente constituída, sem a necessidade de lavratura prévia de escritura pública. Assim, para valer contra terceiros, basta constituir a hipoteca na própria cédula e registrá-la diretamente no cartório de imóveis. Requer, assim, menos tempo e menos despesas administrativas.

Em face do que foi escrito anteriormente, a criação da cédula de crédito bancário parece coadunar-se bem com as categorias indicadas no capítulo 1 . Na dimensão da previsibilidade, garante a certeza da relação jurídica que enseja a emissão da cédula, vez que ela é criada como título de crédito, o que lhe garante autonomia e exigibilidade independentemente do acordo que lhe deu origem. Sendo um título de crédito, pode ser executada judicialmente sem a necessidade de uma fase processual prévia de conhecimento, o que também traz maior previsibilidade.

Na dimensão da celeridade, destaca-se a agilidade na constituição de garantias e na cobrança judicial dos débitos. Nesse ponto, especialmente, há correspondências exatas entre a medida implementada e as regras valorizadas pela Law and Finance, já que permite "descrição genérica de débitos em contratos com garantias" e demanda menor quantidade de tempo e de procedimentos para fazer cumprir o contrato pela via judicial. A despeito de demandar a individualização das garantias prestadas, ao admitir a garantia real por bens futuros, fungíveis e consumíveis ${ }^{135}$, passa a admitir também a "descrição genérica dos ativos que servem de garantia".

\footnotetext{
${ }^{135}$ Lei 10.931, artigo 31, transcrito na nota anterior.
} 
Quadro 7 - Cédula de crédito bancário nos documentos oficiais

Medida proposta

Criação da cédula de crédito bancário

Incidência

\begin{tabular}{|l|l|l|}
\hline Documento & Data & Status \\
\hline BCB, Juros e spread bancário no Brasil & $10 / 1999$ & - \\
\hline BCB, Juros e spread bancário no Brasil & $11 / 2000$ & Implementado \\
\hline BCB, Juros e spread bancário no Brasil & $11 / 2001$ & Implementado \\
\hline BCB, Economia bancária e crédito & $12 / 2002$ & Implementado \\
\hline BCB, Economia bancária e crédito & $12 / 2004$ & Implementado \\
\hline BCB, Relatório de economia bancária e crédito & 2005 & Implementado \\
\hline SPE/MF, Reformas microeconômicas... & $12 / 2004$ & Implementado \\
\hline
\end{tabular}

"Disjetivos

"Disseminar a utilização de um título de crédito mais simples e eficaz no trâmite judicial.

Justificativas

"A legislação brasileira admite dois regimes para efeito de execução judicial de dívidas. No âmbito civil, os contratos dependem de prova, o que demanda uma fase de conhecimento, que têm demorado até 4 anos, dado o congestionamento de processos no Judiciário. Com a utilização de títulos de crédito, típicos do direito comercial, a execução judicial independe de prova e da longa demora da fase de conhecimento, o que permitiria reaver créditos em prazos bem mais curtos. Nesse sentido, o BC deve propor a criação das Cédulas de Crédito Bancário, em substituição a atual exigência de contratos das operações de crédito, utilizáveis para os empréstimos e financiamentos com ou sem garantia. Além de redução de custos e uma melhor defesa do consumidor, estes instrumentos poderiam ser mais facilmente exigíveis em processos na Justiça, reduzindo o risco de crédito." 137

\section{Referências citadas}

\section{Observações}

No relatório de 2003 do PJSB, a medida proposta não é a criação da cédula de crédito

bancário, mas a transformação da MPV 2.160-25, de 23/08/2001, em Lei.

\subsection{Aumento do alcance da alienação e da cessão fiduciárias}

\subsubsection{Contexto}

A alienação fiduciária em garantia foi introduzida no direito brasileiro pela Lei 4.728, de 14/07/1965. Essa lei previa a transferência da propriedade resolúvel e da posse indireta de

\footnotetext{
${ }^{136}$ BCB, Juros e spread bancário no Brasil, 2000, p. 44; 2001, p. 24; BCB, Economia bancária e crédito, 2002, p. 35; 2004, p. 44; BCB, Relatório de economia bancária e crédito, 2005, p. 24.

${ }^{137}$ BCB, Juros e spread bancário no Brasil, 1999, p. 26.
} 
um bem móvel para o credor, como garantia do cumprimento de uma obrigação pelo devedor, que se tornava possuidor direto do bem em questão. ${ }^{138}$

Verificado o inadimplemento da obrigação garantida, o credor - e proprietário da coisa alienada fiduciariamente - poderia retomar a posse direta do bem, vendê-lo a terceiros e usar o valor obtido com a venda para satisfazer seu crédito e saldar as despesas com a realização da garantia. ${ }^{139}$

Desde a sua introdução, a sistemática da alienação fiduciária permaneceu praticamente inalterada. Porém, o âmbito de bens que poderiam ser objeto de alienação foi ampliado ao longo dos anos: a Lei 6.404, de 15/12/1976, permitiu a alienação fiduciária de ações das sociedades anônimas; ${ }^{140}$ a Lei 9.514, de 20/11/1997, possibilitou a de bens imóveis; e a MPV $2.160,{ }^{141}$ de 28/06/2001, admitiu a de coisas fungíveis nas operações no âmbito do mercado financeiro e de capitais. Na verdade, o objetivo da MPV 2.160 era assentar as discussões sobre o alcance da alienação fiduciária, estipulando de modo inequívoco que também os bens móveis fungíveis eram passíveis de serem alienados fiduciariamente. ${ }^{142}$

Poucos meses depois de editada a MPV, contudo, o Novo Código Civil (Lei 10.406, de 10/01/2002) foi promulgado. Nele, a propriedade fiduciária é definida como "propriedade resolúvel de coisa móvel infungível que o devedor, com escopo de garantia, transfere ao credor". Desde então, passou-se a discutir se o Novo Código Civil havia derrogado as extensões dos bens alienáveis promovidas pelas Leis 6.404 e 9.514 e pela MPV $2.160 .{ }^{143}$

\footnotetext{
${ }^{138}$ Lei 4.728, artigo 66, caput. Revogada.

${ }^{139}$ Idem, $\$ 4^{\circ}$. Idem.

${ }^{140}$ Artigo 40.

${ }^{141}$ Inicialmente, MPV 2.065, de 22/06/2001, revogada pela MPV 2.160-23, de 28/06/2001 e reeditada em 26/06 e em 23/08/2001. Foi revogada pela Lei 10.931.

${ }^{142}$ ColOMBo, G. Lei $n^{\circ}$ 10.931/04: alterações na legislação sobre alienação fiduciária. São Paulo: Pinheiro Neto, 2004, p. 2. Disponível em: http://www.ibrademp.org.br.

${ }^{143}$ Colombo, Lei $n^{o}$ 10.931/04, 2004. Monteiro, W. B. Curso de Direito Civil, 37. ed. São Paulo: Saraiva, 2003, p. 246, é citado como um jurista que defende a derrogação pelo Novo Código Civil. Sendo o Novo Código Civil uma lei geral, é discutível que ele tenha poder de revogar lei especial.
} 
A MPV 2.160, independentemente dessa discussão, vigorou até 2004, quando foi revogada pela Lei 10.931, de 02/08/2004. Dentre muitas outras disposições, ${ }^{144}$ essa lei reafirmou a possibilidade de alienação fiduciária de bens imóveis e de cessão fiduciária de direitos creditórios decorrentes de contratos de alienação de imóveis, e passou a admitir a alienação fiduciária de bens enfitêuticos. ${ }^{145}$

Para as operações realizadas no mercado financeiro ou de capitais, a Lei 10.931 reafirmou, ainda, a admissão da alienação fiduciária de coisas fungíveis e a cessão fiduciária de títulos de crédito e de direitos sobre coisas móveis. ${ }^{146}$ Nesses casos, não havendo disposição em contrário, serão atribuídas ao credor as posses (direta e indireta) da coisa objeto de alienação fiduciária, do título representativo do direito ou do crédito. Por fim, vale mencionar que a Lei 10.931 manteve regra de realização da garantia já prevista pela MPV 2.160: no caso de inadimplência do devedor, o credor pode vender o bem alienado fiduciariamente, "independentemente de leilão, hasta pública ou qualquer outra medida judicial ou extrajudicial". ${ }^{147}$

A Lei 10.931 foi usada, ainda, para dar resposta a dois questionamentos: inseriu o artigo 1368-A no Novo Código Civil para explicitar a possibilidade de que leis especiais estabeleçam outras espécies de propriedade fiduciária, prevendo para essas hipóteses a aplicação meramente subsidiária do Código Civil. Tendo em conta o critério hierárquico de solução de antinomias aparentes, ${ }^{148}$ essa alteração não seria necessária, já que o Código Civil é uma lei geral. ${ }^{149}$ Ainda assim, quis o legislador que a dúvida fosse respondida de forma inequívoca.

\footnotetext{
${ }^{144}$ Essa lei criou a cédula de crédito bancário, por exemplo.

145 Respectivamente, nos artigos 12, 51 e 57. A Lei 11.481, de 31/05/07, artigo 11, alterou a Lei 9.514 para abarcar também as possibilidades de alienação fiduciária de direito de uso especial para fins de moradia, de direito real de uso, desde que suscetível de alienação e de propriedade superficiária.

146 Artigo 55.

${ }^{147}$ Artigo 22 da MPV 2.160 e artigo 55 da Lei 10.931.

${ }^{148}$ BobBIO, N. Teoria do ordenamento jurídico, 10 ed. Brasília: UnB, 1997, p. 93.

${ }^{149}$ Colombo, Lei $n^{\circ} 10.931 / 04,2004$, p. 5.
} 
Também foi esclarecido que o procedimento de busca e apreensão dos bens objeto de garantia fiduciária, previsto no Decreto-Lei 911/69, está à disposição apenas de instituições financeiras. ${ }^{150}$

\subsubsection{Lógica de intervenção}

Em razão de prever a transferência do bem ou direito para o patrimônio do credor e em face de as instituições financeiras poderem contar, no caso de inadimplemento, com um procedimento ágil para tomar a posse direta da coisa dada em garantia, a alienação fiduciária é vista por credores como uma das formas de garantia que mais segurança dá nos contratos de crédito bancário. Segundo o próprio BCB:

[...] a alienação fiduciária é um contrato inquestionável e que conta com uma garantia física executável $[\ldots]^{151}$

A alienação fiduciária pode ser descrita como a forma mais eficiente de constituir garantia na realização de uma operação de crédito, pois significa a efetiva transferência da posse de um bem à outra pessoa (credor fiduciário) para garantia do pagamento da obrigação. No caso de não pagamento da obrigação, basta ao credor (fiduciário) vender o bem para cobrir a dívida e as despesas incorridas nesse procedimento, entregando ao devedor eventual saldo remanescente, acompanhado dos respectivos demonstrativos e comprovantes das operações realizadas. ${ }^{152}$

Com as alterações promovidas pela MPV 2.160 e, depois, pela Lei 10.931, a alienação fiduciária ficou ainda mais atrativa para os credores bancários. Primeiro, porque diminui o risco de contestação judicial quanto aos bens e direitos que podem ser objeto de alienação fiduciária. A possibilidade de alienar-se fiduciariamente os bens móveis fungíveis, por exemplo, é estipulada de modo inequívoco.

\footnotetext{
${ }^{150}$ Colombo, Lei $n^{o}$ 10.931/04, 2004, p. 5. Rizzardo, Contratos de crédito bancário, 2003, p. 379.

${ }^{151} \mathrm{BCB}$, Economia bancária e crédito, 2003, p. 24. Nesse relatório do PJSB, todos os textos são assinados e neles se lê a ressalva de que não refletem necessariamente a posição do BC. Essa seção do documento, "Ações e Medidas" é assinada por Eduardo Lundberg, por Eduardo Rodrigues e pela "Equipe do DEPEP/SP".

${ }^{152}$ BCB, Economia bancária e crédito, 2002, p. 30.
} 
Segundo, porque amplia a gama de objetos passíveis de servir como garantia fiduciária, estendendo a eles os ágeis procedimentos de busca e apreensão, no caso de inadimplemento perante instituições financeiras.

Terceiro, porque explicita a dispensa de formalidades ou o envolvimento do Poder Judiciário na realização da garantia, que independe do consentimento do devedor.

Quarto, porque estipula que, salvo disposição contratual em contrário, o bem objeto de alienação ou o título representativo do crédito ou do objeto de cessão fiduciária ficarão na posse direta e indireta do credor. Ou seja, em regra, o credor não precisa lançar mão sequer dos procedimentos de busca e apreensão especialmente voltados às instituições financeiras. E, ficando com a posse direta da coisa ou do seu título representativo, elimina a possibilidade de o devedor valer-se, de maneira oportunista, da garantia para fins diversos que não o de respaldar a obrigação assumida.

Quinto e último, por se tratar de garantia autoliquidável, a concessão de crédito lastreada nesse tipo de negócio jurídico não contamina a carteira de crédito do banco. Agências de rating costumam destacar positivamente esse tipo de garantia na avaliação de risco de instituições financeiras. ${ }^{153}$

De modo amplo, a medida de extensão do alcance da alienação fiduciária aumenta o nível de proteção dos credores nas dimensões da previsibilidade e da celeridade, vez que prevê mecanismos para minorar os riscos de comportamento oportunista do devedor, dá soluções inequívocas para temas que eram objeto de discussões judiciais e confere mais agilidade para os processos de constituição e realização de garantias.

Considerando-se os indicadores usados pela Law and Finance para avaliar o nível de proteção dos credores fora de casos de falência, pode-se dizer que a medida atende a dois

\footnotetext{
${ }^{153}$ É o caso da Moody’s Global Banking. Na avaliação da carteira de crédito do Banco Pine, por exemplo, essa agência de rating destaca a representatividade de operações com garantias autoliquidáveis como um ponto forte do banco analisado. Cf. Moody's Global Banking. Credit Opinion, 16 jan. 2007, p. 2. Disponível em: http://ri.bancopine.com.br/bancopine/web/arquivos/BANCOPINE_MOODYS_20080128_PORT.pdf.
} 
deles: por um lado, permite que os credores tomem posse das garantias e as vendas sem ter de recorrer aos tribunais. Por outro, ao prever que "salvo disposição contratual em contrário" a posse do bem ou do direito que serve de garantia caberá ao credor, acaba por permitir, $a$ contrario sensu, a possibilidade de as partes negociarem sobre os procedimentos de cobrança.

De certo modo, ao afirmar que o procedimento de busca e apreensão está à disposição somente de instituições financeiras, a Lei 10.931 acaba por explicitar que qualquer pessoa poderá constituir garantia fiduciária, porém somente àquelas que captam poupança popular é reservado o uso de um procedimento especial para retomada da posse direto do bem dado em garantia. Dessa forma, essa explicitação também pode ser associada a outro indicador usado pela Law and Finance: "possibilidade de qualquer pessoa conceder ou receber garantias relativas à propriedade". Como a regra menciona somente a concessão de garantias, a correspondência é parcial.

\section{Quadro 8 - Alienação e cessão fiduciárias nos documentos oficiais}

\section{Medida proposta}

Aumento do alcance da alienação e da cessão fiduciárias

\section{Incidência}

\begin{tabular}{|l|l|l|}
\hline Documento & Data & Status \\
\hline BCB, Juros e spread bancário no Brasil & $11 / 2000$ & Proposta \\
\hline BCB, Juros e spread bancário no Brasil & $11 / 2001$ & Implementado \\
\hline BCB, Economia bancária e crédito & $12 / 2002$ & Implementado \\
\hline BCB, Economia bancária e crédito & $12 / 2004$ & Implementado \\
\hline BCB, Relatório de economia bancária e crédito & 2005 & Implementado \\
\hline SPE/MF, Reformas microeconômicas... & $12 / 2004$ & Implementado \\
\hline
\end{tabular}

\section{Objetivos}

"Aumentar o alcance desse eficiente instituto de garantia ao crédito, antes restrita apenas a bens móveis." 154

\section{Justificativas}

"Visa aproximar a legislação brasileira às práticas existentes em mercados internacionais."155

\section{Referências citadas}

\section{Observações}

No relatório de 2003 do PJSB, a medida proposta não é a criação da cédula de crédito bancário, mas a transformação da MPV 2.160-25, de 23/08/2001, em Lei.

\footnotetext{
${ }^{154} \mathrm{BCB}$, Economia bancária e crédito, 2004, p. 45; BCB, Relatório de economia bancária e crédito, 2005, p. 24. ${ }^{155} \mathrm{BCB}$, Juros e spread bancário no Brasil, 2000, p. 45.
} 


\subsection{Reconhecimento do acordo para compensação de pagamentos}

\subsubsection{Contexto}

No mercado financeiro em geral, mas especialmente nas operações com derivativos, ${ }^{156}$ é comum a vigência simultânea de vários contratos entre as mesmas partes, que figuram alternativamente como contraentes e como contratadas. ${ }^{157}$ À medida em que esses contratos vencem, uma parte ora assume a posição de credor, ora a de devedor. Na dinâmica normal do mercado, presume-se que as obrigações são cumpridas à medida que vencem os prazos contratuais. No curso da vigência dos contratos, contudo, pode acontecer de uma das partes tornar-se insolvente. Caso seja decretada a falência da parte insolvente, a parte solvente pode vir a ser obrigada a saldar débitos presentes, independentemente da existência de créditos futuros com a mesma empresa falida.

As medidas sugeridas pelo PJSB e implementadas pela MPV 2.192/2001 ${ }^{158}$ e pela Lei $10.214 / 2001^{159}$ visaram a contornar essas situações. Na prática, elas afastam um dos efeitos da decretação de falência, aquele que proíbe a extinção de obrigações entre a parte solvente e a parte insolvente, ainda que elas sejam ao mesmo tempo credoras e devedoras uma da outra. ${ }^{160}$

Para os participantes do Sistema de Pagamentos Brasileiro (SPB), ${ }^{161}$ a Lei 10.214/2001 assim dispõe:

\footnotetext{
${ }^{156}$ Mercado futuro, a termo, de opções e de swaps.

${ }^{157}$ PRADO, F. R. A.; LESSA, T. A. D. T.; SPINA, A. O reconhecimento da validade de acordos para compensação de débitos e créditos em operações financeiras: a nova regulamentação do Conselho Monetário Nacional. Disponível em www.migalhas.com.br, acesso em 5 out. 2008.

${ }^{158}$ Conforme informado anteriormente, a MPV 2.139-67, de 22/06/2001, foi a primeira que previu a possibilidade de realização de acordo para compensação de pagamentos (artigo 30). Estranhamente, a MPV 2.139-67, bem como suas versões anteriores, diz respeito ao Programa de Incentivo à Redução do Setor Público Estadual na Atividade Bancária (PROES).

${ }_{159}$ Produto de conversão da MPV 2.115-16, de 23/02/2001, originalmente MPV 2.008, de 05/12/1999.

${ }^{160}$ Decreto-Lei 7.661, de 21/06/1945, artigo 43, e Lei 11.101, de 09/02/2005, artigo 117. A própria Lei 11.101 já prevê a exceção da compensação de pagamentos no artigo 119, VIII.

${ }^{161}$ O SPB é o conjunto de entidades, procedimentos e sistemas integrados para transferir fundos de pagadores para recebedores. É no âmbito do SPB, por exemplo, que são realizados os serviços de compensação e de liquidação de cheques, de ordens de cobrança registradas em instituições financeiras (bloquetos de cobrança), de ordens de crédito, tais como DOC (Documento de Crédito) e TED (Transferência Eletrônica Disponível). Cf. Circular 3.057, artigo $3^{\circ}$.
} 
Art. $7^{\circ}$. Os regimes de insolvência civil, concordata, intervenção, falência ou liquidação extrajudicial, a que seja submetido qualquer participante, não afetarão o adimplemento de suas obrigações, assumidas no âmbito das câmaras ou prestadores de serviços de compensação e de liquidação, que serão ultimadas e liquidadas pela câmara ou prestador de serviços, na forma de seus regulamentos.

Para as operações realizadas fora do SPB, mas no âmbito do Sistema Financeiro Nacional (operações de balcão), a MPV 2.192/2001 determina:

\begin{abstract}
Art. 30. É admitida a realização de acordo para a compensação e a liquidação de obrigações no âmbito do Sistema Financeiro Nacional, nas hipóteses e segundo as normas estabelecidas pelo Conselho Monetário Nacional.

$\S 1^{\circ}$ A realização da compensação e da liquidação nos termos e nas condições acordados, não será afetada pela decretação de insolvência civil, concordata, intervenção, falência ou liquidação extrajudicial da parte no acordo, não se aplicando o disposto na parte final do caput do art. 43 e inciso I do art. 52, ambos do Decreto-Lei no 7.661, de 21 de junho de 1945.
\end{abstract}

Ao mesmo tempo em que permitem o vencimento antecipado e a compensação entre créditos e débitos, essas medidas evitam a prática de cherry picking pelo administrador judicial da massa falida, que poderia escolher, conforme a conveniência da massa, quais contratos seriam cumpridos e quais não seriam. Com a possibilidade da compensação de pagamentos, caso seja firmado um acordo com esse fim específico entre as partes contratantes, o administrador da eventual massa falida deixa de ter a prerrogativa dessa escolha.

A mesma Lei 10.214, que possibilitou a realização de acordos para a compensação de pagamentos no SPB, também ampliou as formas de proteção das operações realizadas nesse âmbito: as operadoras que atuam em sistemas tidos como sistemicamente relevantes devem fazê-lo como contraparte, e os bens oferecidos em garantia de operações realizadas nos sistemas de compensação e liquidação são impenhoráveis. A despeito de as justificativas para essas alterações serem de fundo sistêmico, elas não deixam de reforçar o sistema de garantias e de ampliar o nível de proteção dos credores. 


\subsubsection{Lógica de intervenção}

A possibilidade da compensação de pagamentos atende a uma preocupação primordialmente sistêmica. Trata-se de um mecanismo que busca evitar que a crise de insolvência de um agente propague-se pelo sistema financeiro e contamine outros participantes do mercado, pois isso criaria a possibilidade de quebras sucessivas e, ao final, a instalação de uma crise que comprometa a higidez de todo o sistema. ${ }^{162}$

Ainda que a medida vise a atender a segurança do sistema financeiro, ela pode ser associada à diminuição do risco moral do devedor, uma das categorias trabalhadas no capítulo 1, já que a compensação de pagamentos limita um dos efeitos usuais da decretação da falência: a prerrogativa do administrador da massa de escolher quais contratos devem ser cumpridos e quais não devem. Com a compensação de pagamentos, o devedor não poderá agir caprichosamente, cumprindo os contratos mais vantajosos para a massa e condenando os demais a pleitear indenização. ${ }^{163}$ Havendo o acordo para compensação, esta deverá ser realizada por força de lei, independentemente da vontade do administrador.

Ao limitar a discricionariedade do agente na escolha de contratos a serem cumpridos, o direito é usado como meio para restringir as alternativas de comportamento que possam ser prejudiciais às expectativas econômicas, ainda que se admita a impossibilidade de se antever todos comportamentos futuros dos indivíduos. A compensação de pagamentos prioriza, assim, a dinâmica das transações financeiras: retira a decisão sobre cumprir ou não cumprir o contrato da esfera de controle do administrador da massa, em nome da regularidade dos comportamentos e da higidez do sistema financeiro.

\footnotetext{
162 Sobre risco e crise sistêmicos, cf. C. GoODHART et al. Financial regulation: why, how and where now? Londres: Routledge, 1998.

${ }^{163}$ BANCO Mundial. Principles and guidelines for effective insolvency and creditor rights systems, 2001, p. 37. Disponível em: http://siteresources.worldbank.org/GILD/PrinciplesAndGuidelines/20162797/Principles\%20and\%20Guidelines\% 20for\%20Effective\%20Insolvency\%20and\%20Creditor\%20Rights\%20Systems.pdf.
} 
Quadro 9 - Acordo para compensação de pagamentos (SPB) nos documentos oficiais

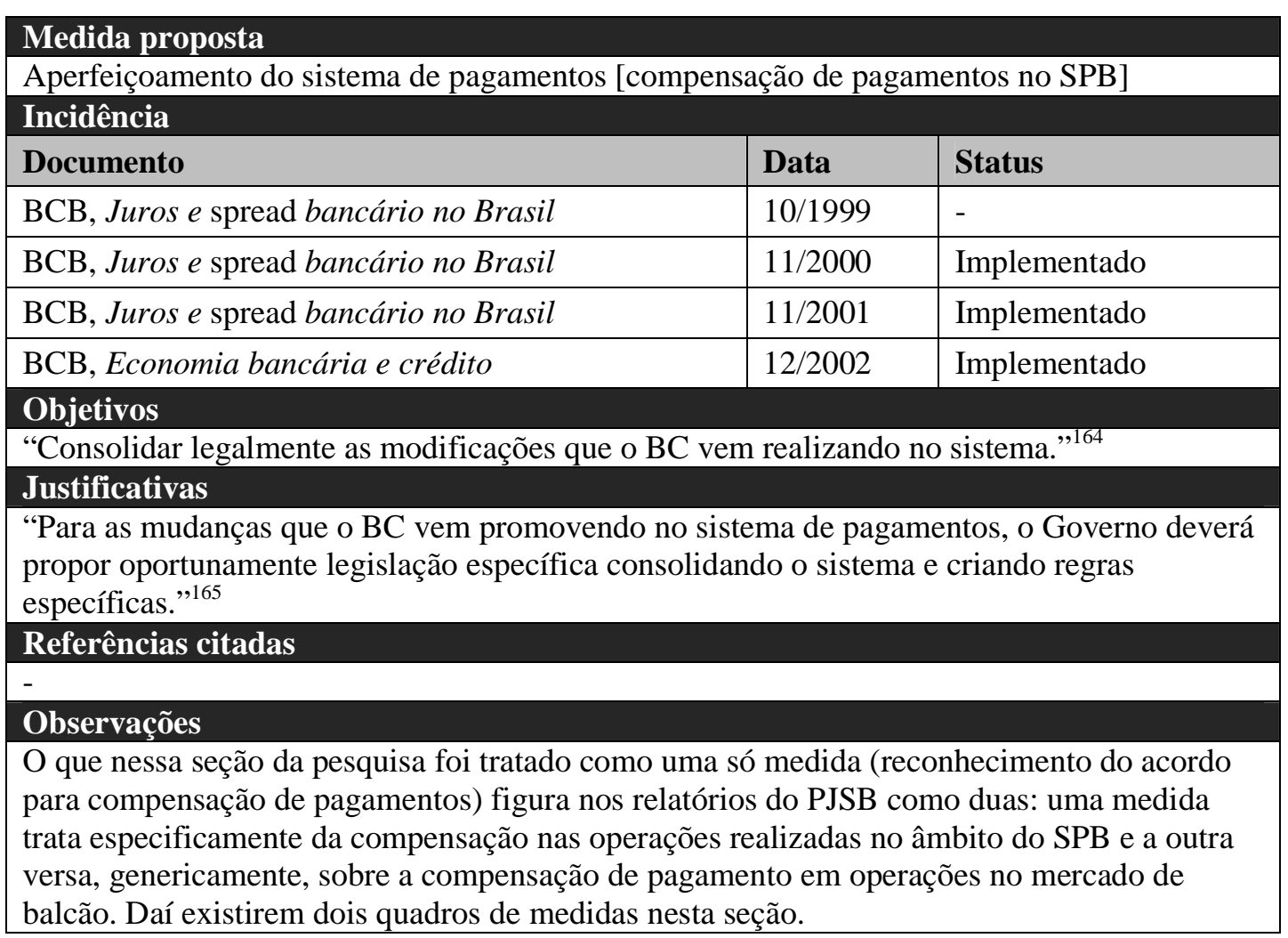

${ }^{164}$ BCB, Juros e spread bancário no Brasil, 1999, p. 15; 2000, p. 44; 2001, p. 24 e BCB, Economia bancária e crédito, 2002, p. 35.

${ }^{165}$ BCB, Juros e spread bancário no Brasil, 1999, p. 26. 
Quadro 10 - Acordo para compensação de pagamentos (mercado de balcão) nos documentos oficiais

\section{Medida proposta}

Reconhecimento do acordo para compensação de pagamentos [mercado de balcão]

\section{Incidência}

\begin{tabular}{|l|l|l|}
\hline Documento & Data & Status \\
\hline Juros e Spread Bancário no Brasil & $11 / 2000$ & Proposta \\
\hline Juros e Spread Bancário no Brasil & $11 / 2001$ & Implementado \\
\hline BCB, Economia bancária e crédito & $12 / 2002$ & Implementado \\
\hline BCB, Economia bancária e crédito & $12 / 2004$ & Implementado \\
\hline BCB, Relatório de economia bancária e crédito & 2005 & Implementado \\
\hline
\end{tabular}

\section{Objetivos}

"Assegurar a compensação de posições em instrumentos derivativos em casos de decretação de regime especial em instituições financeiras e não-financeiras."

\section{Justificativas}

"Visa aproximar a legislação brasileira às práticas existentes em mercados internacionais."16

\section{Referências citadas}

\section{Observações}

No relatório de 2003 do PJSB, a medida proposta não é exatamente o reconhecimento do acordo para compensação de pagamentos, mas a transformação da MPV 2.192-70, de 23/08/2001, em Lei. Esta MPV regula a compensação de pagamentos no mercado de balcão.

\subsection{Previsão legal do crédito consignado em folha de pagamento}

\subsubsection{Contexto}

A Lei 10.820 , de $17 / 12 / 2003,{ }^{168}$ prevê a possibilidade de empregados celetistas autorizarem o desconto, diretamente na folha de pagamento, de débitos decorrentes de contratos de empréstimo, de financiamento e de arrendamento mercantil. Faz o mesmo em relação a aposentados e pensionistas do Instituto Nacional do Seguro Social (INSS). Com isso, cria um novo instrumento de crédito, marcado por baixo risco de inadimplência e, por isso, mais atrativo para as instituições financeiras e mais barato para o tomador de recursos.

\footnotetext{
${ }^{166}$ BCB, Economia bancária e crédito, 2004, p. 46; BCB, Relatório de economia bancária e crédito, 2005, p. 2627.

${ }^{167}$ BCB, Juros e spread bancário no Brasil, 2000, p. 45.

${ }^{168}$ Produto de conversão da MPV 130, de 17/09/2003. A Lei $\mathrm{n}^{\circ} 10.953$, de 27/09/2004, alterou o artigo $6^{\circ}$ da Lei 10.820/2003, detalhando algumas regras para a concessão de crédito consignado na folha de pagamento de aposentados e pensionistas do INSS.
} 
Esse baixo risco decorre das características desse instrumento de crédito, que associa as características do crédito consignado em folha ao aumento do nível de proteção ao credor, na dimensão da previsibilidade, e à redução de custos de transação.

Antes disso, vale mencionar que a eventual abusividade de cláusulas contratuais que prevejam desconto em folha de pagamento foi objeto de apreciação do STJ. No julgamento do Recurso Especial 728.563/RS, a Seção de Direito Privado do STJ assentou o entendimento de que não são abusivas as cláusulas que prevejam o desconto em folha. No voto do relator, lê-se: 169

O que me parece não ter cabimento é alguém obter um financiamento a taxas mais favorecidas, justamente porque optou por uma modalidade de consignação em folha de pagamento, o que ainda o dispensou de apresentação de garantia suplementar e ainda obtendo prazo mais elástico, com redução de cada parcela, e, em seguida, sob alegação de expropriação abusiva, excluir a cláusula, o que denota, inclusive, o nítido propósito de inadimplir a obrigação, porquanto se assim não for, então qual a razão para alijar a consignação?

A despeito de referir-se a contrato firmado por um funcionário público municipal, antes da vigência da MPV 130, o relator menciona as possibilidades de consignação previstas pelas Leis 8.112 (Estatuto do Servidor Público Federal) e $10.820 .{ }^{170}$ E diz que, independentemente dessas regramento, não vê impedimento na lei processual para tal tipo de avença. ${ }^{171}$ Afastou-se, assim, a possibilidade de aplicação, a casos como esses, do artigo 649, IV, do CPC, que proíbe a penhora de rendas, pois esse dispositivo, segundo o STJ, refere-se a procedimento de execução judicial.

\footnotetext{
${ }^{169}$ Recurso Especial 728.563/RS, interposto pela Cooperativa de Economia e Crédito Mútuo dos Servidores Públicos Municipais de Porto Alegre (Cooperpoa) em face de Paulo Ricardo do Amaral Elias, voto do relator, Ministro Aldir Passarinho Junior, p. 5-6.

${ }^{170}$ Voto do relator, p. 5.

${ }^{171}$ Voto do relator, p. 5.
} 


\subsubsection{Lógica de intervenção}

A previsão legal do crédito consignado em folha de pagamento é tida como umas das mais eficientes medidas para a redução do spread bancário numa modalidade específica. ${ }^{172}$ As taxas de juros praticadas nessa modalidade de crédito - mais baixas que as do crédito pessoal convencional, por exemplo - são comumente associadas a três vantagens do sistema de crédito consignado: (a) à reduzida assimetria de informação entre credor e devedor, no momento da contratação e no curso da execução do contrato; $(b)$ à impossibilidade de o devedor priorizar o pagamento de outras despesas, em detrimento do pagamento do seu débito; e, por fim, $(c)$ aos baixos custos administrativos envolvidos no recebimento, pelo credor, dos pagamentos devidos.

Uma vez solicitado pelo empregado, o empregador é obrigado a repassar para o potencial credor (instituição consignatária) todas as informações necessárias para as contratações previstas na Lei $10.820 .{ }^{173}$ Como são os salários e as verbas rescisórias que lastrearão os contratos, é praticamente pleno o nível de informação relevante sobre a capacidade de pagamento do trabalhador.

Já que a autorização para o desconto em folha é dada de modo irrevogável e irrefutável e uma vez que é obrigação do empregador reter os valores devidos pelo empregado, não há como o devedor, diante de uma despesa imprevista, escolher se vai ou não pagar o que deve. ${ }^{174}$ Mantendo o emprego, não há a possibilidade de comportamento oportunista do devedor. ${ }^{175}$ Sendo assim, são mais baixos os custos de monitoramento dos credores em relação às hidden actions do devedor. ${ }^{176}$

\footnotetext{
${ }^{172}$ RoDRIGUES, E. et al. O efeito da consignação em folha nas taxas de juros dos empréstimos pessoais. In: BCB, Relatório de economia bancária e crédito. Brasília, 2005, p. 89-101; CosTA, A. C.; MELlO, J. M. Judicial risk and credit market performance: micro evidence from Brazilian payroll loans. NBER. Working paper 12.252, mai. 2006; PJSB; SPE/MF, Reformas microeconômicas e crescimento de longo prazo, p. 32.

${ }^{173} \mathrm{O}$ artigo $3^{\circ}$ da Lei 10.820 obriga o empregador, desde que solicitado pelo seu funcionário, a prestar à instituição consignatária as informações necessárias para a contratação.

${ }^{174}$ RoDRIGUES et al., O efeito da consignação em folha nas taxas de juros dos empréstimos pessoais, 2005, p. 90; SPE/MF, Reformas microeconômicas e crescimento de longo prazo, p. 32.

${ }^{175}$ O relatório de 2007 do PJSB, que está fora do recorte temporal desse trabalho, traz texto que mostra preocupação com os casos de devedores que mudam de emprego. Por isso, propõe que sejam cobrados juros mais altos durante o período de desemprego, de maneira a incentivar que o mutuário comunique o quanto antes os dados do novo empregador e, assim, seja retomado o desconto em folha, a taxas menores. Uma vez
} 
A Lei 10.820 determina, ainda, que os valores retidos devem ser repassados diretamente pelo empregador às instituições consignatárias e que os eventuais custos administrativos podem ser também descontados na folha de pagamento do empregado. ${ }^{177}$ Deduz-se, assim, que as despesas administrativas do credor com essa modalidade de crédito são menores do que em outras.

Também aqui surge com clareza a intenção de reduzir-se a possibilidade de risco moral do devedor, no curso da execução do contrato. A Lei 10.820 permite que proventos futuros sejam usados para garantir o pagamento de débitos e retira da esfera de escolha do devedor a decisão sobre pagar ou não as parcelas devidas, ainda que ocorram mudanças significativas em suas condições pessoais. Além disso, ao obrigar o empregador a certos procedimentos e ao permitir que ele repasse para o empregado os custos com esses procedimentos, a lei acaba por transferir custos de transação relevantes para o devedor, mesmo numa transação de risco diminuto para o credor. Com isso, aumentam-se a eficiência do negócio e a qualidade das informações que o credor tem sobre o devedor; e diminui-se a possibilidade de comportamento oportunista do devedor (risco moral). Em outras palavras, ganha-se em previsibilidade e em eficiência, dois vetores presentes na literatura da Law and Finance e nas categorias de análise expostas no capítulo 1.

desempregado o devedor, a operação passa a ser de crédito pessoal convencional. Cf. CHU, V.; LUNDBERG, E.; TAKEDA, T. Por que o volume de empréstimo consignado no setor privado é tão baixo? Qual a solução? In: BCB, Relatório de economia bancária e crédito, 2007. p. 80-81 [texto inteiro: 73-83].

${ }^{176}$ RoDRIGUES et al., O efeito da consignação em folha nas taxas de juros dos empréstimos pessoais, 2005, p. 90, nota 3.

${ }^{177}$ Artigo $3^{\circ}, \S 2^{\circ}$. 
Quadro 11 - Consignação em folha nos documentos oficiais

\section{Medida proposta}

Previsão legal do crédito consignado em folha de pagamento

Incidência

\begin{tabular}{|l|l|l|}
\hline Documento & Data & Status \\
\hline BCB, Economia bancária e crédito & $12 / 2003$ & - \\
\hline BCB, Economia bancária e crédito & $12 / 2004$ & Implementado \\
\hline BCB, Relatório de economia bancária e crédito & 2005 & Implementado \\
\hline SPE/MF, Reformas microeconômicas... & $12 / 2004$ & Implementado \\
\hline Objetivos & &
\end{tabular}

"Transformar a MPV 130, de 17/09/2003, em lei.".178

Justificativas

"A MPV já foi aprovada na Câmara e no Senado (20/11/2003), faltando apenas a sanção do Presidente da República." 179

Referências citadas

\section{Observações}

\subsection{Reforma da Lei de Falências}

\subsubsection{Contexto}

De 1945 a 2005, o direito falimentar brasileiro foi regido basicamente pelo DecretoLei 7.661, de 21/06/1945. Cinco décadas depois de sua decretação e diante de profundas alterações na economia brasileira, o Decreto 7.661/1945 foi taxado de anacrônico, excessivamente rígido e com mecanismos inadequados para lidar com situações de insolvência de grandes empresas. ${ }^{180}$

$\mathrm{Na}$ avaliação do impacto do direito falimentar sobre o desenvolvimento do mercado de crédito, os documentos oficiais objeto desse estudo apontam como problemas os seguintes aspectos da legislação que vigorou até 2005 :

\footnotetext{
${ }_{178} \mathrm{BCB}$, Economia bancária e crédito, 2003, p. 33.

${ }^{179}$ BCB, Economia bancária e crédito, 2003, p. 33.

${ }^{180}$ BANCO Mundial. Resolution of Financial Distress: An International Perspective on the Design of Bankruptcy Laws. Washington: Banco Mundial, 2001, p. 53; SPE/MF, Reformas microeconômicas e crescimento de longo prazo, p. 81 .
} 
- Ordem de satisfação dos credores no processo de falência, com prioridade para os créditos trabalhistas e fiscais; ${ }^{181}$

- Ausência de incentivos para o envolvimento dos credores, que poderiam fiscalizar e cobrar agilidade nos processos falimentares; ${ }^{182}$

- Leilão público como única forma de venda de ativos da massa falida; ${ }^{183}$

- Sucessão nos débitos fiscais e trabalhistas para quem compra ativos da massa falida, inviabilizando negócios que poderiam manter as unidades produtivas e evitar o sucateamento de ativos; ${ }^{184}$

- Limitação da concordata como mecanismo de recuperação da empresa em dificuldades. Tratava-se de mera concessão - pelo juiz e sem envolvimento dos credores - de moratória para o pagamento de créditos quirografários. De fato, atingiam somente

[...] fornecedores e prestadores de serviços, que não podem deixar de ser pagos, sob risco de cessar o recebimento de mercadorias e serviços necessários para a continuação de suas atividades. O que se quer, normalmente, é renegociar créditos bancários, em geral sujeitos a algum contrato com garantia e, portanto, não alcançados pelo instituto da concordata. ${ }^{185}$

- Exigência de unanimidade entre os credores para a realização de acordos informais, já que a mera convocação de credores para renegociação de dívida poderia ser interpretada como um "ato falimentar" do devedor, ensejando o pedido de falência pelos credores. ${ }^{186}$

\footnotetext{
${ }^{181} \mathrm{BCB}$, Economia bancária e crédito, 2002, p. 51; BCB, Economia bancária e crédito, 2003, p. 47.

${ }_{182} \mathrm{BCB}$, Economia bancária e crédito, 2002, p. 51; BCB, Economia bancária e crédito, 2003, p. 47.

${ }^{183}$ BCB, Economia bancária e crédito, 2002, p. 53.

${ }^{184} \mathrm{BCB}$, Economia bancária e crédito, 2002, p. 51; BCB, Economia bancária e crédito, 2003, p. 47.

${ }^{185}$ BCB, Economia bancária e crédito, 2002, p. 55; BCB, Economia bancária e crédito, 2003, p. 47.

${ }^{186} \mathrm{BCB}$, Economia bancária e crédito, 2002, p. 55.
} 
Como dito, o Decreto-Lei 7.661/1945, principal alvo dessas críticas, vigorou até 2005, quando foi revogado pela Lei 11.101 , de 09/02/2005. Essa Lei é produto da aprovação do Projeto de Lei 4.376, enviado ao Congresso Nacional pelo Poder Executivo em 21/12/1993 e substancialmente alterado no curso da tramitação na Câmara dos Deputados e no Senado Federal. ${ }^{187}$ Também em 09/02/2005, foi promulgada a Lei Complementar 118, que altera dispositivos de direito falimentar previstos do Código Tributário Nacional (CTN).

\subsubsection{Lógica de intervenção}

A proposta de alteração da Lei de Falências como medida para redução do spread bancário aparece já no primeiro relatório do PJSB, não com sugestões de uma reforma ampla do Decreto-Lei 7.661/1945, mas com uma proposta de priorização dos créditos com garantias reais. É o que se depreende do seguinte trecho:

[...] quando da falência de empresas, as instituições financeiras tem apresentado dificuldade no recebimento de créditos com garantia real. As garantias reais são uma forma universal de reduzir o risco de crédito nas operações de crédito, favorecendo o tomador com juros substancialmente mais baixos. No entanto, se essas garantias não são aceitas ou válidas quando a empresa é liquidada judicialmente, a entrega de garantias pelo tomador para a redução dos juros perde muito de sua eficácia. Por isso, deve-se propor medidas alterando a lei de falências, para dar maior proteção aos créditos garantidos nas liquidações judiciais. ${ }^{188}$

Nos relatórios de 2000 e 2001, é mencionado que o Banco Central do Brasil está a estudar o Projeto de Lei 4.376/1993, com vistas a apresentar sugestões de melhoria do projeto que, então, tramitava na Câmara dos Deputados. Antecipando as conclusões que seriam divulgadas em 2002, o PJSB de 2001 anuncia:

Nossa avaliação é o de que nosso sistema judiciário de falências e de recuperação de empresas poderia funcionar melhor, beneficiando os credores e a melhor alocação dos recursos produtivos na economia. O procedimento da falência é bastante demorado e em geral resulta em baixa recuperação para os credores da massa. A concordata é uma alternativa rígida e de pouca flexibilidade para a recuperação de empresas, com o sistema judiciário não dando um amparo adequado às alternativas informais de salvamento empresarial. Além disso, a rigidez das regras de sucessão tributária,

\footnotetext{
${ }^{187}$ Número na Câmara dos Deputados, onde o PL tramitou por quase 10 anos e passou por profundas alterações em relação à versão original. No Senado Federal recebeu o número 71/2003.

${ }^{188}$ BCB, Juros e spread bancário no Brasil, 1999, p. 27.
} 
relativamente a vendas de estabelecimentos comerciais, fundos de comércio e bens de empresas em dificuldades, é um fator importante de desvalorização desses bens, prejudicando ainda mais os credores das falências e dificultando as recuperações de empresas. $^{189}$

A amplitude dessa avaliação prévia indica que as sugestões de alteração do projeto de lei não se restringiriam à priorização de créditos com garantias reais. Isso se confirma no relatório de 2002, que dedica à Lei de Falências uma subseção do capítulo Ações e medidas para a redução do spread bancário. ${ }^{190}$

Segundo o PJSB, ${ }^{191}$ o Projeto de Lei 4.376, tal como proposto em 1993, não alterava de maneira substancial regras com possíveis impactos diretos sobre o mercado de crédito, pois: (a) mantinha a ordem de classificação dos créditos inscritos no concurso universal de credores do processo de falência, dando prioridade para os credores trabalhistas e para o Fisco; (b) não previa formas de ampliar a participação dos credores nos processos de tentativa de recuperação de empresas insolventes viáveis ou mesmo na liquidação de empresas inviáveis; (c) não propunha meios mais céleres para a venda de ativos das empresas falidas; e (d) não previa flexibilizar as regras de sucessão tributária para aqueles que comprassem esses ativos.

Durante a tramitação no Congresso Nacional, o Projeto de Lei foi profundamente alterado, especialmente a partir da versão adotada em 30/11/1999, ${ }^{192}$ quando passou a ser conhecido como "Projeto Biolchi", em referência a Oswaldo Biolchi, à época, relator do projeto de lei na Câmara dos Deputados.

Ao comentar essa versão do projeto de lei, o relatório de 2002 do PJSB diz que ela é inovadora em muitos aspectos, embora não esgote o estoque de medidas necessárias para dar eficiência ao direito falimentar brasileiro. ${ }^{193}$ São mencionadas as seguintes inovações: $(a)$ limitação quantitativa dos créditos trabalhistas a serem satisfeitos prioritariamente no processo de falência; (b) maior envolvimento dos credores nos processos de falência e de recuperação

\footnotetext{
${ }^{189} \mathrm{BCB}$, Juros e spread bancário no Brasil, 2001, p. 18.

${ }^{190}$ BCB, Economia bancária e crédito, 2002, p. 49 a 58.

${ }^{191}$ BCB, Economia bancária e crédito, 2002, p. 51.

192 "Submenda Global às Emendas de Plenário ao Substitutivo Adotado pela Comissão Especial ao Projeto de 4.376/1993”, publicado no Diário da Câmara dos Deputados, de 06/09/2003, p. 43.783 a 43.830.

${ }^{193}$ BCB, Economia bancária e crédito, 2002, p. 52, 56-57.
} 
de empresas; (c) previsão da recuperação extrajudicial de empresas, que reconhece os acordos informais entre devedor e credores, afastando a ideia de que a mera convocação de reuniões pelo credor para discutir dívidas seja interpretada como ato falimentar, ensejando o pedido de falência pelos credores; $(d)$ ampliação dos procedimentos de venda dos ativos do devedor falido, antes restritos ao leilão público; $(e)$ simplificação dos procedimentos para recuperação judicial de micro e pequenas empresas, dispensando-as de apresentar um plano formal de recuperação e prevendo um padrão para recomposição de dívidas, em "24 prestações mensais, iguais e sucessivas", mas sem afastar a possibilidade de outros arranjos, desde que haja a aprovação dos credores; e $(f)$ previsão de que os créditos concedidos durante o processo de recuperação não entram no concurso universal de credores, tendo, assim, prioridade absoluta sobre todos os créditos, no caso de decretação da falência.

O relatório de 2002 do PJSB sugere, ainda, três modificações no Projeto Biolchi e em um dispositivo específico do CTN. Primeiro, limitar o prazo de suspensão das ações e execuções, previsto para o intervalo entre o pedido e a aprovação do plano de recuperação de empresa. Sem limite temporal definido, a recuperação poderia ser usada como mero instrumento de protelação do pagamento de dívidas.

Segundo, rever a posição do Fisco na ordem de prioridade para o recebimento de créditos e limitar o privilégio dos credores trabalhistas, como forma de ampliar o envolvimento dos credores na administração e na fiscalização dos processos de falência.

E, terceiro, alterar o CTN, de maneira que seja evitada a sucessão em obrigações tributárias pela pessoa de boa-fé que adquire imóveis e unidades produtivas de empresas falidas. Com isso, seria facilitada a venda de ativos de empresas em liquidação, evitando o sucateamento dos bens.

Em 09/02/2005, ao cabo do processo legislativo, foram promulgadas a Lei Ordinária 11.101 - que incorporou todas as modificações descritas acima como inovações do Projeto de Lei 4.376/1993, na versão de 30/11/1999 - e a Lei Complementar 118, que alterou disposições de direito falimentar previstas no CTN. 
Sobre as três demandas de alteração sugeridas pelo relatório de 2002 do PJSB, o resultado foi o seguinte:

- Uma vez deferido o pedido de processamento da recuperação judicial da empresa, ficam suspensas por 180 dias as ações e execuções em face do devedor em dificuldades; ${ }^{194}$

- Os créditos com garantia real passam à frente dos créditos tributários na ordem de prioridades do processo de falência; e os créditos trabalhistas passam a ter prioridade sobre todos os demais, mas no limite de 150 salários mínimos por credor; ${ }^{195}$

- A sucessão tributária prevista no caput do artigo 133 do CTN deixa de incidir sobre a aquisição de filial ou de unidade produtiva isolada, nos processos de recuperação de empresas, e sobre as compras de ativos, no processo de falência. ${ }^{196}$

O conteúdo das sugestões de alteração feitas pelo relatório de 2002 do PJSB ao Projeto de Lei 4.376/1993 pode ser associado às duas dimensões da proteção dos credores expostas no capítulo 1 - previsibilidade e celeridade -, especialmente quando são consideradas as medidas para o controle do comportamento do devedor, para a diminuição da discricionariedade judicial e para o aumento da agilidade na realização de garantias.

A concretização desses valores pode ser vista com clareza em quatro comentários do PJSB a respeito do Projeto Biolchi. Os comentários dizem respeito: (a) à suspensão automática das ações e execuções contra o solicitante de processo de recuperação, $(b)$ ao

\footnotetext{
${ }^{194}$ Lei 11.101, artigo $6^{\circ}$. Prosseguem somente as ações que demandam quantia ilíquida, conforme exceção prevista no $\S 1^{\circ}$.

${ }_{195}$ CTN, artigo 186, parágrafo único, incisos I e II, alterado pela Lei Complementar 118, de 09/02/2005; Lei 11.101 , artigo 83 .

${ }^{196} \S 1^{\circ}$ ao artigo 133 do CTN, incluído pela Lei Complementar 118, de 09/02/2005. Para a não-ocorrência de sucessão tributária, exige-se que a alienação seja feita em juízo e que o adquirente não seja sócio da empresa falida ou em recuperação, nem parente do devedor falido ou em recuperação (artigo 133, § $2^{\circ}$ ).
} 
envolvimento dos credores na recuperação de empresas, $(c)$ à ordem de satisfação dos credores no processo de falência e $(d)$ à sucessão tributária na venda dos ativos da massa falida.

No que diz respeito ao primeiro item, o projeto de lei, quando foi comentado pelo Banco Central, já previa, como mencionado, a suspensão automática das ações e execuções movidas contra a empresa que solicitou recuperação judicial. Não previa, contudo, a duração dessa suspensão. Segundo o relatório de 2002 do PJSB:

\begin{abstract}
O período de paralisação ("stand still”) de processos, está previsto no projeto, mas sem delimitação de prazo, o que pode ensejar abusos de empresas que possam utilizar-se do instrumento sem nenhuma intenção de efetivamente promoverem a recuperação judicial da empresa. O ideal é que fosse estabelecido, por exemplo, um prazo máximo de 45 a 60 dias para essa paralisação, prorrogável uma única vez por igual período, o que seria razoável para o encaminhamento e aprovação de um plano de recuperação. ${ }^{197}$
\end{abstract}

Nota-se que a justificativa para a estipulação de um limite de prazo para a carência é de fundo comportamental: sendo automática a concessão, a inexistência de limite temporal pode ser interpretada como um incentivo para o uso oportunista do pedido de recuperação. A fixação de prazo poderia diminuir o risco (moral) de devedores solicitarem a recuperação apenas para se valer da moratória concedida automaticamente, sem que haja qualquer interesse em recuperar a empresa.

Em relação ao envolvimento dos credores no processo de recuperação de empresas, quando apreciado pelo BCB, o Projeto de Lei 4.376/1993 já previa a participação dos credores na aprovação do plano de recuperação. Assim, o PJSB não demandou a alteração do projeto de lei nesse ponto, mas se posicionou a respeito:

[...] [Na versão original do Projeto de Lei 4.376], a recuperação judicial continuava tendo um tratamento de "favor legal", podendo ser deferida pelo juiz sem um processo formal de consulta ou aprovação pelos credores. [...] [O] projeto foi alterado para que esse instituto acompanhe a experiência internacional de onde ele foi inspirado, deixando de ser um favor legal para ser um instrumento de renegociação de dívidas sob supervisão judicial. Com essas alterações recentes, passou a se exigir a apreciação e aprovação formal do plano de recuperação por uma assembléia de credores [...]. Cabe ao juiz, após certificar-se da lisura dos aspectos legais e processuais, homologar a decisão e garantir legitimidade ao plano de recuperação e a sua implementação. Essa

\footnotetext{
${ }^{197}$ BCB, Economia bancária e crédito, 2002, p. 56. O prazo máximo de suspensão contido na Lei 11.101, artigo
} $6^{\circ}, \S 4^{\circ}$, é 180 dias e não é passível de prorrogação. 
postura tem a vantagem de valorizar as práticas de mercado e propiciar um ambiente sadio de recuperação de empresas, antecipando, agilizando e dando previsibilidade às ações e decisões a serem adotadas. ${ }^{198}$

Nessa passagem, a previsibilidade é associada ao papel meramente homologador a ser desempenhado pelo juiz, que não deve interferir no acordo aprovado entre credores e a empresa em recuperação. O mesmo deve acontecer quando há rejeição do plano de recuperação pela Assembleia de Credores: caberá ao juiz decretar a falência da empresa. ${ }^{199}$ Dessa forma, são valorizadas a liberdade de contrato e a posição dos credores. Do juiz, esperase tão-somente que aprecie a lisura do procedimento, ratifique o acordo privado e, quando for o caso, empregue os meios de execução forçada contra o devedor insolvente.

Sobre a ordem de prioridade dos credores no processo de falência, diz o PJSB 2002:

[...] temos dúvida se há vantagem econômica para o fisco receber à frente dos demais credores. Hoje, o fisco tem prioridade no recebimento de um duvidoso crédito de uma massa falida abandonada pelos credores, mal administrada e muitas vezes objeto de abusos a título de cobrança de créditos trabalhistas. Acreditamos ser melhor para o próprio fisco receber mais rapidamente um valor menor, mas certo, em igualdade de condições com os demais credores. [.... $]^{200}$

Direitos e conquistas trabalhistas são importantes, mas só fazem sentido quando a empresa existe e é economicamente saudável. Já no caso de uma empresa falida, com recursos insuficientes para saldar todos os seus compromissos, é preciso reavaliar a prioridade de tais direitos trabalhistas face ao direito dos demais credores. Nesses casos, sem afrontar a legislação trabalhista, a alternativa mais sensata seria manter um pagamento prioritário a título de alimentos, delimitando um valor máximo em moeda ou um teto de até 3 salários por trabalhador. Os valores e direitos que ultrapassassem esse valor ou teto continuariam sendo reconhecidos legalmente, mas ficariam pendentes de pagamento de acordo com o rateio dos recursos disponíveis da massa falida, em igualdade de condições com os demais credores. ${ }^{201}$

Segundo o PJSB, o fato de os credores com garantia real serem apenas a terceira classe de credores a ser satisfeita no processo de falência faz com que as garantias reais se desvalorizem e com que não haja incentivo para o envolvimento dos credores na governança dos processos de insolvência. Como, provavelmente, os créditos trabalhistas e fiscais

\footnotetext{
${ }^{198}$ BCB, Economia bancária e crédito, 2002, p. 56.

${ }^{199}$ Lei 11.101, artigo 56, $\S 4^{\circ}$.

${ }^{200} \mathrm{BCB}$, Economia bancária e crédito, 2002, p. 54.

${ }^{201}$ BCB, Economia bancária e crédito, 2002, p. 54. Pela Lei 11.101, artigo 83, I, os créditos trabalhistas têm prioridade somente até o limite de 150 salários mínimos por credor.
} 
esgotarão o patrimônio da massa falida e os credores com garantias reais nada terão a receber ao cabo da liquidação, eles não se interessam pelo processo de falência. Pelo mesmo motivo, o valor econômico das garantias reais diminuem, pois, em regra, não servirão para honrar os débitos do devedor falido.

No que tange à venda de ativos, o BCB elogia o fato de o Projeto Biolchi prever "melhor discriminação das regras e abertura de um leque maior de opções, além do leilão tradicional, para a venda dos ativos da empresa falida", ${ }^{202}$ mas vaticina que ele ainda não é capaz de dar eficiência ao processo de alienação judicial, "pois a burocracia envolvida continua sendo excessiva e o valor dos imóveis e instalações continua sendo depreciado por conta do problema da sucessão de obrigações". ${ }^{203}$ Em vista disso, sugere que sejam incluídas salvaguardas no CTN, de modo que os adquirentes de ativos da massa falida não corram o risco de serem compelidos a pagar tributos que incidiram sobre os bens antes da aquisição.

Conforme exposto no capítulo 1, a Law and Finance considera quatro condições na medição do nível de proteção dos credores na falência. São eles: (i) se é dada prioridade aos credores com garantias reais; (ii) se a responsabilidade pela gestão da empresa durante o processo de recuperação permanece com o devedor; (iii) se há o congelamento automático dos ativos; e, por último, (iv) se há restrições para solicitar o processo de recuperação, como o consentimento dos credores. Esses indicadores são medidos por meio da verificação da existência de regras específicas no direito falimentar dos países objeto da pesquisa comparativa. Segundo essa régua, terão o maior nível de proteção dos direitos dos credores os países que: (i) dão prioridade aos credores com garantia real; (ii) transferem a gestão da empresa para os credores; (iii) não preveem o congelamento automático de ativos; e (iv) impõem restrições para os pedidos de recuperação, exigindo-se, por exemplo, o consentimento dos credores.

Há perfeita correspondência entre o disposto na Lei 11.101/2005 e um desses indicadores: "previsão de restrições para entrar em recuperação, tais como a necessidade de

\footnotetext{
${ }^{202}$ BCB, Economia bancária e crédito, 2002, p. 52.

${ }^{203}$ BCB, Economia bancária e crédito, 2002, p. 51.
} 
haver consentimento dos credores”. Quanto aos demais indicadores, não é possível identificar correspondência imediata com a legislação aprovada em 2005. Nela: (i) há suspensão automática das ações e execuções contra empresas em recuperação ou falidas, o que cria impedimentos para que os credores com garantias tomem posse dos bens que respaldam seus créditos; (ii) os credores com garantia real não têm prioridade no recebimento de seus créditos no processo de falência, pois ocupam a segunda posição na classificação dos credores da massa falida, atrás dos credores trabalhistas; e (iii) os administradores da empresa em dificuldades permanecem na gestão durante o processo de recuperação. ${ }^{204}$

Por outro lado, caso sejam considerados os comentários feitos pelo Banco Central do Brasil $^{205}$ sobre o projeto de lei, pode-se dizer que as sugestões de alteração buscaram aproximar determinados dispositivos do texto das "boas práticas" corporificadas em dois outros indicadores: "inexistência de congelamento de ativos" e "prioridade para credores com garantias reais". Como visto, em face de um projeto de lei que previa um congelamento de ativos que poderia durar todo o processo de recuperação, o BCB propôs a fixação de um limite de duração; diante de um projeto que mantinha a ordem de satisfação dos credores na falência, o BCB propôs: que se valorizassem as garantias reais, que o Fisco recebesse em igualdade de condições com os demais credores e que fossem limitados os créditos trabalhistas.

Quanto à quarta e última categoria de Law and Finance, "gestão da empresa não continua sob a responsabilidade dos devedores", apesar de valorizar a participação dos credores na administração, o BCB não chega a sugerir claramente que os credores assumam a gestão da empresa em recuperação. ${ }^{206}$

Em suma, há um alto grau de correspondência entre as medidas sugeridas pelo BCB e as regras valorizadas pela Law and Finance na proteção dos direitos dos credores em casos de insolvência de devedores. O mesmo não se pode dizer sobre a lei que, ao cabo do processo legislativo, foi aprovada pelo Congresso Nacional e sancionada pelo presidente da República.

\footnotetext{
${ }^{204}$ Lei 11.101/2005, artigo 64: "Durante o procedimento de recuperação judicial, o devedor ou seus administradores serão mantidos na condução da atividade empresarial, sob fiscalização do Comitê, se houver, e do administrador judicial [...]".

${ }^{205}$ BCB, Economia bancária e crédito, 2002, p. 49-58.

${ }^{206}$ BCB, Economia bancária e crédito, 2002, p. 53 e 54.
} 


\section{Quadro 12 - Reforma da Lei de Falências nos documentos oficiais}

\section{Medida proposta}

Reforma da Lei de Falências

Incidência

\begin{tabular}{|l|l|l|}
\hline Documento & Data & Status \\
\hline BCB, Juros e spread bancário no Brasil & $10 / 1999$ & - \\
\hline BCB, Juros e spread bancário no Brasil & $11 / 2000$ & Proposta \\
\hline BCB, Juros e spread bancário no Brasil & $11 / 2001$ & Em estudo \\
\hline BCB, Economia bancária e crédito & $12 / 2002$ & Em estudo \\
\hline BCB, Economia bancária e crédito & $12 / 2003$ & - \\
\hline BCB, Economia bancária e crédito & $12 / 2004$ & Em implementação \\
\hline BCB, Relatório de economia bancária e crédito & 2005 & Implementado \\
\hline SPE/MF, Reformas microeconômicas... & $12 / 2004$ & Implementado $^{207}$ \\
\hline Objetivos & & \\
\hline
\end{tabular}

"Modificar a lei de falências visando maior proteção dos credores no recebimento de empréstimos junto a empresas insolventes.",208

"Aumentar a proteção e reduzir os riscos do sistema financeiro nacional resultantes de empresas e instituições que se tornem insolventes." 209

"Proteger os credores na eventual insolvência da empresa devedora e valorizar o sistema de garantias reais ao crédito." 210

\section{Justificativas}

"Quando da falência de empresas, as instituições financeiras tem apresentado dificuldade no recebimento de créditos com garantia real. As garantias reais são uma forma universal de reduzir o risco de crédito nas operações de crédito, favorecendo o tomador com juros substancialmente mais baixos. No entanto, se essas garantias não são aceitas ou válidas quando a empresa é liquidada judicialmente, a entrega de garantias pelo tomador para a redução dos juros perde muito de sua eficácia. Por isso, deve-se propor medidas alterando a lei de falências, para dar maior proteção aos créditos garantidos nas liquidações judiciais." ${ }^{211}$ Referências citadas

ARAÚJO, A.; LUNDBERG, E. A Nova Lei de Falências: uma avaliação. In: BCB, Economia bancária e crédito, 2003, p. 44-57. ${ }^{212}$

GETTING the Deal Through Series. Insolvency \& Restructuring. Londres: Law Business Research, 2003 [quadro comparativo de países selecionados: prioridades dos credores na falência].

\section{Observações}

\footnotetext{
${ }^{207}$ A Lei, na verdade, só foi sancionada em 2005.

${ }^{208}$ BCB, Juros e spread bancário no Brasil, 1999, p. 16.

${ }^{209} \mathrm{BCB}$, Juros e spread bancário no Brasil, 2000, p. 45

${ }^{210}$ BCB, Economia bancária e crédito, 2004, p. 46.

${ }^{211} \mathrm{BCB}$, Juros e spread bancário no Brasil, 1999, p. 27.

${ }^{212}$ BCB, Economia bancária e crédito, 2003, p. 29.
} 


\subsection{Racionalização dos processos judiciais}

\subsubsection{Contexto}

A rubrica "racionalização dos processos judiciais", adotada nos relatórios de 2003 a 2005 do Projeto Juros e Spread Bancário, abriga algumas das medidas propostas na Reforma do Judiciário, aquelas com impacto previsto sobre o mercado de crédito. Da etapa constitucional da Reforma (mudanças realizadas pela Emenda Constitucional 45, de 30/12/2004), é mencionada a súmula vinculante; e, da etapa infraconstitucional da Reforma, são mencionadas as alterações no sistema recursal e no sistema de execução dos títulos judiciais e extrajudiciais, bem como a previsão de procedimento para o julgamento de processos repetitivos.

O objetivo visado pelas medidas de racionalização dos processos judiciais é a remoção de obstáculos procedimentais que provocam congestionamento no Poder Judiciário. Nessa esteira, a previsão constitucional das súmulas vinculantes tem o propósito de criar um mecanismo para que o STF possa fazer valer em toda a jurisdição suas orientações a respeito de certos temas, evitando-se decisões dissonantes de órgãos inferiores em assuntos já assentados no órgão de cúpula do Poder Judiciário. Com isso, quer-se evitar a necessidade de a parte ter de passar por todas as instâncias possíveis para ver afirmada, somente muitos anos depois, uma posição que já vinha sendo repisada pelo STF em casos semelhantes. Em outras palavras, o propósito dessa medida é dar ao STF o poder para editar súmulas que sejam obrigatoriamente aplicadas por todos os juízes, evitando-se julgamentos divergentes em assuntos pacificados pelo STF.

As medidas da etapa infraconstitucional da Reforma do Judiciário mencionadas nos documentos objeto dessa pesquisa foram sugeridas para atacar, principalmente, problemas identificados no processo de execução e no sistema recursal. No processo de execução, foram identificados dois problemas principais: $(a)$ a citação do devedor e $(b)$ a penhora de bens. 
A citação é o ato que instaura a relação processual. No processo de execução, ela comunica ao executado a existência de um processo contra ele e o insta a pagar a dívida ou a indicar bens à penhora. A penhora é o ato que atrela determinados bens à execução, a serem expropriados para satisfação do exequente.

Segundo dados citados pela Secretaria de Reforma do Judiciário do Ministério da Justiça, $48 \%$ das potenciais relações processuais executivas não caminham por falta de citação, pois o devedor não é encontrado; nos processos em que o devedor é encontrado e a citação feita, $41 \%$ dos processos param na fase de penhora dos bens, pois o devedor não os nomeia. ${ }^{213} \mathrm{E}$, em muitos casos, quando o faz, indica bens de difícil liquidação. ${ }^{214}$

\section{Gráfico 3 - Processo de execução: citação, penhora e embargos}

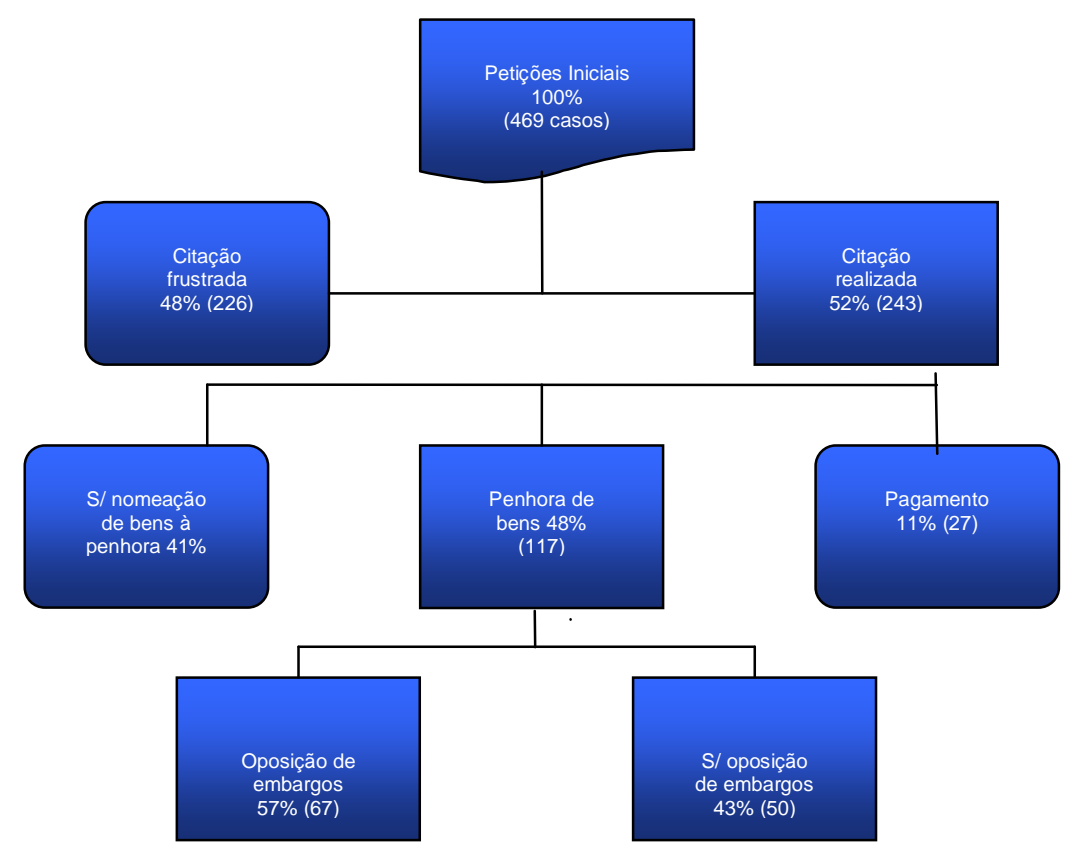

Fonte: Banco Mundial, apud SRJ/MJ. ${ }^{215}$

213 Banco Mundial, 2003, apud SRJ/MJ, Judiciário e Economia, 2005, p. 14-15. Disponível em: http://www.adpema.org/pdf/JudiciarioeEconomia.pdf. Os dados abrangem 469 casos da justiça do Estado de SP.

${ }^{214}$ SRJ/MJ, Judiciário e Economia, 2005, p. 15. Não é indicada a porcentagem de executados que assim procedem.

${ }^{215}$ Idem nota 213. 
Com o propósito de resolver essas dificuldades, foram realizadas alterações no rito executivo previsto no CPC. A primeira delas, implementada pela Lei 11.232, de 22/12/2005, foi a junção, num só processo, das fases de conhecimento e de execução do processo civil. Com isso, o que era um processo autônomo de execução de título judicial passa a ser mera etapa de cumprimento de sentença, dispensando-se a necessidade de citação para dar início às medidas de execução forçada contra o devedor condenado. ${ }^{216}$

A citação pessoal do réu condenado, que dava a notícia da existência de um processo de execução contra ele, foi substituída pela intimação. Nos casos de condenação por obrigação de quantia certa, essa intimação insta o réu-executado a cumprir a obrigação em quinze dias, sob pena de incidir multa de $10 \%$ sobre o valor devido. ${ }^{217}$ Caso não o faça, o próprio autorexequente pode indicar bens do devedor-executado à penhora. Para garantir agilidade, sempre que possível, o oficial de justiça realizará a penhora e a avaliação dos bens na mesma diligência.

Antes da Lei 11.232/2005, a defesa do executado era feita mediante a oposição de embargos. Com as alterações feitas, a defesa na fase de cumprimento da sentença será feita por meio de impugnação que, em regra, não terá efeito suspensivo. ${ }^{218}$

Alterações semelhantes também foram feitas pela Lei 11.382 , de 06/12/2006, no rito da execução por título extrajudicial: o próprio credor pode indicar, na petição inicial, os bens do devedor a serem preferencialmente penhorados; e o auto de penhora e de avaliação será lavrado na mesma diligência do oficial de justiça.

Na execução por título extrajudicial, o meio de defesa continua a ser os embargos. Somente para esse procedimento, a Lei 11.382 faz referência a "comportamentos meramente protelatórios" em três passagens distintas. ${ }^{219}$

\footnotetext{
${ }^{216}$ CPC, artigos 475-I a 475-R.

${ }^{217} \mathrm{CPC}$, artigo 475-J.

${ }^{218} \mathrm{CPC}$, artigo $475-\mathrm{M}$.

${ }^{219}$ Lei 11.382 , artigo $2^{\circ}$. Dentre outras coisas, essa lei altera o CPC para coibir o uso dos embargos como meio de procrastinação do feito processual. Com a nova redação dada pela Lei 11.382, os "comportamentos meramente
} 
Ainda na execução por título extrajudicial, vale citar a alteração nos meios de expropriação dos bens do devedor. Dada a sua ineficiência, o leilão em hasta pública será usado somente em último caso. Assim, os meios prioritários para expropriação serão: adjudicação pelo próprio credor, por preço não inferior ao da avaliação; alienação por particular ou agentes credenciados, sob a supervisão do juiz; alienação em hasta pública, mediante procedimentos mais simplificados e menos anacrônicos de divulgação. ${ }^{220}$

No sistema recursal, os gargalos identificados foram (a) a quantidade de recursos interpostos para instâncias superiores, em processos julgados em primeiro, segundo e terceiro graus de jurisdição; e $(b)$ o volume de ações sobre os mesmos temas em curso no STF.

Esse problema pode ser ilustrado pela tabela a seguir, que indica as taxas de recorribilidade externa, ou seja, o percentual de decisões contestadas em instância superior àquela que a proferiu:

Tabela 2 - Índice de recorribilidade externa

\begin{tabular}{|c|c|c|}
\hline \multicolumn{2}{|c|}{ ÂMBITO } & ÍNDICE \\
\hline \multicolumn{2}{|c|}{ Superior Tribunal de Justiça } & $8,94 \%$ \\
\hline \multicolumn{2}{|c|}{ Tribunal Superior do Trabalho } & $9,37 \%$ \\
\hline \multirow{3}{*}{ 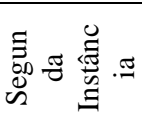 } & Justiça Federal & $36,61 \%$ \\
\hline & Justiça do Trabalho & $42,19 \%$ \\
\hline & Justiça Estadual & $20,28 \%$ \\
\hline \multirow{3}{*}{ 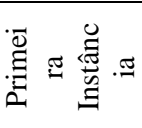 } & Justiça Federal & $30,53 \%$ \\
\hline & Justiça do Trabalho & $55,41 \%$ \\
\hline & Justiça Estadual & $13,51 \%$ \\
\hline \multicolumn{2}{|l|}{ Média } & $27,11 \%$ \\
\hline
\end{tabular}

Fonte: STF, apud SRJ/MJ 221

protelatórios" são mencionados nos artigos do CPC: artigo 739, inciso III; artigo 740, parágrafo único; e artigo $746, \S 3^{\circ}$

${ }^{220}$ SPE/MF, Reformas microeconômicas e crescimento de longo prazo, p. 77. Exposição de Motivos que acompanhou o PL 4.497/2004, Cf. Diário da Câmara dos Deputados, 01/12/2004, p. 51.765.

${ }^{221}$ Supremo Tribunal Federal, 2005, [A Justiça em números: dados estatísticos do Judiciário brasileiro] apud SRJ/MJ, Judiciário e Economia, 2005, p. 16. 
Quanto ao volume de processos sobre os mesmos temas, dados de 2005 citados pela Secretaria de Reforma do Judiciário mostram que 58\% dos processos em curso no STF diziam respeito a apenas 45 temas. $^{222}$

Para contornar esses óbices, o CPC foi alterado, com vistas a otimizar o julgamento de processos sobre matérias repetitivas e evitar o uso de recursos como instrumentos procrastinatórios. Com as alterações promovidas pelas Leis 11.187, de 19/10/2005, e 11.276 e 11.277, ambas de 07/02/2006, o CPC:

- Faz da forma retida a regra de interposição do recurso de agravo. Com isso, o agravo de instrumento fica reservado às hipóteses em que a decisão interlocutória contestada puder causar lesão grave ou de difícil reparação à parte que o interpôs. ${ }^{223}$

- Determina que o juiz não receba recurso de apelação contra sentença proferida em conformidade com súmula do STF ou do STJ. ${ }^{224}$

- Quando a matéria controvertida for exclusivamente de direito, permite que o juiz julgue de pronto, sem citar o réu, casos idênticos a outros já decididos pelo juízo como totalmente improcedentes. 25

\subsubsection{Lógica de intervenção}

As medidas de "racionalização dos processos judiciais" são sugeridas a partir do diagnóstico que associa a morosidade do Poder Judiciário a uma estrutura de incentivos que se

\footnotetext{
${ }^{222}$ Cf. SRJ/MJ, Judiciário e Economia, 2005, p. 15. Esses dados foram gerados pelo próprio STF na pesquisa $A$ Justiça em números e se baseou no universo de 99.326 processos classificados por assunto em 04/05/2005.

${ }^{223}$ CPC, artigos 522, 523 e 527, alterados pela Lei 11.187, de 19/10/2005.

${ }^{224} \mathrm{CPC}$, artigo 518, $\S 1^{\circ}$, acrescentado pela Lei 11.276, de 07/02/2006. Além dessa alteração, a Lei 11.276 modifica o CPC para permitir que o próprio tribunal determine a realização ou renovação de atos processuais nos casos em que, no curso da apelação, forem identificadas nulidades sanáveis nos processos. Pelo regime anterior, os autos deveriam retornar ao juízo de origem para que o vício fosse sanado. No regime atual, o tribunal determina as diligências e, uma vez sanada a nulidade, prossegue no julgamento da apelação.

${ }^{225}$ CPC, artigo 285-A, acrescentado pela Lei 11.277 , de 07/02/2006.
} 
mostram perversos seja para o desenvolvimento do mercado de crédito, seja para o próprio Poder Judiciário.

Ao receber o sinal de um processo moroso, o devedor de má-fé pode enxergar no Poder Judiciário um meio para adiar o pagamento de dívidas. O que deveria funcionar como um incentivo a mais para pagar seus débitos (função dissuasória) pode ser visto como uma boa alternativa ao cumprimento temporâneo de suas obrigações. Sabedoras dessa possibilidade, as instituições financeiras aumentam o prêmio de risco de crédito e embutem nos custos de financiamento as despesas que incorrerão no caso de terem de se valer da cobrança judicial dos seus créditos. Com o aumento dos custos, menos pessoas terão acesso ao crédito e menor será o mercado. É o que se depreende, por exemplo, do seguinte trecho, extraído do RMCLP:

\begin{abstract}
Em relação à resolução de conflitos no âmbito dos contratos econômicos em geral, matéria cível na doutrina do direito, tem sido observadas uma série de distorções, em especial, no que se refere à execução contratual. Nos contratos de crédito esse é um tema recorrente. O credor compromete seu capital ou o capital de terceiros em operações cujo prazo médio de recuperação do valor emprestado, em caso de inadimplência, é de 5 anos, em grande parte devido à existência de diversos instrumentos processuais, em especial recursais, que possibilitam a protelação do processo. Essa situação confere grande insegurança jurídica para a concessão do crédito e a contratação em geral, obrigando às empresas a uma série de salvaguardas de elevado custo e um nível sub-ótimo de contratação. ${ }^{226}$
\end{abstract}

Segundo o PJSB, a morosidade do Poder Judiciário e a fartura de opções de recursos incentivam o devedor oportunista a usar o processo como meio de procrastinar o cumprimento de suas obrigações. Dessa forma, aumentam o risco moral de o devedor diminuir seu empenho para fazer frente ao que avençou com o credor.

Além disso, a sinalização de um processo moroso pode provocar uma retroalimentação no congestionamento do Poder Judiciário, pois quanto mais moroso, maior será o incentivo para que mais devedores de má-fé se valham desse expediente para protelar pagamentos. Sendo verificada essa hipótese, morosidade geraria mais morosidade, em um processo cíclico de piora na eficiência dos meios de cobrança de dívidas.

\footnotetext{
${ }^{226}$ SPE/MF, Reformas microeconômicas e crescimento de longo prazo, p. 28.
} 
No âmbito do processo de conhecimento, reduzir as possibilidades de recursos - ou prevê-los tão-somente com efeito devolutivo - e forçar os juízes de instâncias inferiores a aplicar as súmulas do STF são, assim, meios para diminuir as possibilidades de comportamento oportunista do devedor. ${ }^{227}$ Eis a demanda veiculada nos relatórios do PJSB:

Reformar os códigos de processo para reduzir o grande número de recursos e agravos [sic] que retardam o andamento dos processos e adotar súmulas vinculantes ou impeditivas de recursos, de forma que se faça valer a jurisprudência emanada dos tribunais superiores, entre outras medidas simplificadoras. ${ }^{228}$

Conferir celeridade também aos meios de execução é outro objetivo dessas medidas. As mudanças nas regras de penhora (com a indicação prévia de bens a ser feita pelo credor) e o fim dos embargos na execução por título executivo judicial são apontados como instrumentos para diminuir as possibilidades de comportamento oportunista do devedor. Segue trecho com as razões da reforma apresentadas no RMCLP:

[...] propõe-se que o autor passe a indicar os bens do réu a serem penhorados e o fim dos embargos à execução, que tem o efeito automático de suspender o processo, criando a figura da impugnação, sem efeito suspensivo automático.

Essas alterações, além de minorar o oportunismo na indicação dos bens a serem penhorados - como a indicação de bens de difícil avaliação, que acaba ensejando recursos para sua substituição e atrasa o processo - possibilitariam substancial economia de tempo na execução, pois a proposição e a análise dos embargos (agora impugnações) pelo Juiz poderá ter curso simultaneamente ao procedimento de penhora dos bens do réu, e não somente após esse último. ${ }^{229}$

Enfim, as justificativas apresentadas pelos documentos oficiais objeto dessa pesquisa para adoção das medidas de "racionalização dos processos judiciais" dizem respeito especificamente a alterações na estrutura de incentivos sinalizada pelo processo civil brasileiro. Segundo esses documentos, a morosidade do processo e a proteção indevida estimulam "comportamentos inadequados que acabam por prejudicar a todos, encarecendo o custo do crédito". 230

\footnotetext{
${ }^{227}$ SPE/MF, Reformas microeconômicas e crescimento de longo prazo, p. 28 e 74.

${ }^{228}$ BCB, Economia bancária e crédito, 2003, p. 32; 2004, p. 47; BCB, Relatório de economia bancária e crédito, 2005 , p. 26.

${ }^{229}$ SPE/MF, Reformas microeconômicas e crescimento de longo prazo, p. 76 e 77.

${ }^{230} \mathrm{BCB}$, Juros e spread bancário no Brasil, 1999, p. 12.
} 
Dentre as categorias arroladas no capítulo 1, a medida de "racionalização dos processos judiciais" pode ser relacionada à proteção dos interesses dos credores nas dimensões da previsibilidade e da celeridade. Quanto à previsibilidade, busca-se diminuir as possibilidades de o devedor comportar-se de maneira oportunista, seja ao punir a litigância de má-fé, seja conferindo maior velocidade ao processo, para que o tempo deste não seja enxergado pelo devedor como uma boa alternativa ao pagamento em dia de suas obrigações. Ainda nessa dimensão, busca-se também diminuir a possibilidade de discricionariedade judicial, especialmente dos juízes das instâncias inferiores.

No que tange à dimensão celeridade, foram encurtados procedimentos, visando a impactar o custo do litígio e o tempo necessário para se fazer valer os contratos pela via judicial. Com impacto tanto na dimensão da celeridade como na dimensão da previsibilidade, é mencionada o poder vinculante das súmulas emitidas pelo STF.

\section{Quadro 13 - Racionalização dos processos judiciais nos documentos oficiais}

\section{Medida proposta}

Racionalização dos processos judiciais

Incidência

\begin{tabular}{|l|l|l|}
\hline Documento & Data & Status \\
\hline BCB, Economia bancária e crédito & $12 / 2003$ & - \\
\hline BCB, Economia bancária e crédito & $12 / 2004$ & Em implementação \\
\hline BCB, Relatório de economia bancária e crédito & 2005 & Em implementação \\
\hline SPE/MF, Reformas microeconômicas... & $12 / 2004$ & Em implementação \\
\hline Objetivos &
\end{tabular}

"Reformar os códigos de processo para reduzir o grande número de recursos e agravos [sic] que retardam o andamento dos processos e adotar súmulas vinculantes ou impeditivas de recursos, de forma que se faça valer a jurisprudência emanada dos tribunais superiores, entre outras medidas simplificadoras." 231

\section{Justificativas}

"Alguns juízes entendem ser adequado desconsiderar o estabelecido na letra da lei ou nos contratos, alinhando-se com a parte mais fraca da disputa, usualmente o devedor, contra a parte mais forte, o credor, com o intuito de promover justiça social. Ainda que essa atitude seja mais comum nos tribunais inferiores e possa, com freqüência, ser revertida mediante apelação aos tribunais superiores, ela é prejudicial à proteção do credor. Por essa razão, seria importante realizar um esforço em grande escala junto a juízes e à sociedade em geral para mostrar que as decisões que beneficiam um tomador de empréstimo em um processo ${ }^{231}$ BCB, Economia bancária e crédito, 2003, p. 32; 2004, p. 47; BCB, Relatório de economia bancária e crédito,
2005 , p. 26. 
específico têm repercussões amplas, que prejudicam os tomadores de empréstimos como um todo, em um nível mais abrangente., ${ }^{232}$

Referências citadas

Pinheiro, O componente judicial dos spreads bancários, $2003 .^{233}$

Djankov et al. Courts, 2003. ${ }^{234}$

Stliglitz e Weiss, Credit Rationing in Markets with Imperfect Information, $1981 .^{235}$

Fachada, Figueiredo e Lundberg, Sistema judicial e mercado de crédito no Brasil, 2003. ${ }^{236}$

PINHEIRO, A. C. O Judiciário e a Economia no Brasil. São Paulo: IDESP, 2000. Mimeo. ${ }^{237}$

SRJ/MJ - Secretaria da Reforma do Judiciário do Ministério da Justiça. Diagnóstico do

Poder Judiciário. Brasília: Ministério da Justiça, 2004. ${ }^{238}$

Observações

Nos relatórios de 2003 e de 2004 do PJSB, todas as seções são assinadas e neles se lê a ressalva de que as opiniões expressas ali não representam a posição oficial do Governo a respeito dos temas tratados. Em razão disso, os relatórios desses anos não foram invocados na argumentação. A justificativa transcrita neste quadro não foi explorada porque foi extraída do relatório de 2004. Registre-se, contudo, que ela consta da seção "Ações e medidas avaliações e propostas", que descreve iniciativas do PJSB (e não dos autores do texto), segundo diz o próprio texto do relatório. ${ }^{239}$

\footnotetext{
${ }^{232} \mathrm{BCB}$, Economia bancária e crédito, 2004, p. 35-36.

${ }^{233}$ BCB, Economia bancária e crédito, 2003, p. 28; e BCB, Economia bancária e crédito, 2004, p. 35.

${ }^{234}$ SPE/MF, Reformas microeconomicas e crescimento de longo prazo, 2004, p. 26.

${ }^{235}$ SPE/MF, Reformas microeconomicas e crescimento de longo prazo, 2004, p. 26.

${ }^{236}$ SPE/MF, Reformas microeconômicas e crescimento de longo prazo, 2004, p. 72.

${ }^{237}$ SPE/MF, Reformas microeconômicas e crescimento de longo prazo, 2004, p. 26.

${ }^{238} \mathrm{SPE} / \mathrm{MF}$, Reformas microeconômicas e crescimento de longo prazo, 2004, p. 26.

${ }^{239}$ Cf. BCB, Economia bancária e crédito, 2004, p. 31. Os autores do texto são: Eduardo Lundberg, coordenador do PJSB, e Fani Bader, membro da equipe técnica do DEPEP.
} 


\section{Direito, Economia e Política: as InTERfaCes da DotaÇão INSTITUCIONAL}

Ao expor um conjunto de medidas e ao compará-lo com as categorias de análise desenvolvidas no capítulo 1, o capítulo 2 buscou associar a reforma do mercado de crédito brasileiro à perspectiva da dotação institucional, mediante a identificação de um continuum discursivo entre, de um lado, as regras de proteção dos direitos dos credores valorizadas na literatura da Law and Finance e, de outro, as justificativas para a adoção das medidas de reforma dos sistemas de insolvência e de cobrança de dívidas constantes nos relatórios do Projeto Juros e Spread Bancário (PJSB) e no documento Reformas microeconômicas e crescimento de longo prazo (RMCLP).

Partindo da perspectiva da dotação institucional, o objetivo deste capítulo é examinar algumas das premissas que estruturam essa visão, não para debater se as medidas de reforma do mercado de crédito são descabidas ou ineficazes, mas para melhor compreender qual concepção de direito tais medidas pressupõem.

\subsection{A reforma do mercado de crédito brasileiro em documentos do Banco Mundial}

A proximidade entre a perspectiva da dotação institucional e os objetivos e justificativas das medidas sugeridas pelo PJSB e pelo RMCLP pode ser atribuída à influência de programas do Banco Mundial sobre os projetos do Governo Federal. De fato, as medidas aqui analisadas são mencionadas em relatórios do BM, seja como atividades preparatórias para a obtenção de financiamento, seja como atividades de execução de projetos financiados. ${ }^{240}$

$\mathrm{O}$ quadro que segue arrola os projetos de assessoria técnica financiados pelo Banco Mundial que mencionam as medidas de reforma do mercado de crédito aqui estudadas. São

\footnotetext{
${ }^{240}$ Em contrário, poder-se-ia argumentar que o discurso do Governo Federal foi amoldado para satisfazer os ouvidos do Banco Mundial e, com isso, obter-se financiamento para aquilo que o Brasil já pretendia fazer, mesmo sem o financiamento do Banco Mundial.
} 
mencionados somente os projetos que preveem desembolsos para o BCB e para a SPE, entidades autoras dos documentos que são o objeto primário desta pesquisa.

\section{Quadro 14 - Financiamento da reforma do mercado de crédito pelo Banco Mundial}

\begin{tabular}{|c|c|c|c|}
\hline PROJETO & $\begin{array}{c}\text { DATA DA } \\
\text { ASSINATURA }\end{array}$ & ESCOPO PERTINENTE & $\begin{array}{c}\text { TOTAL } \\
\text { FINANCIADO }\end{array}$ \\
\hline $\begin{array}{l}\text { Central Bank } \\
\text { Modernization } \\
\text { Technical } \\
\text { Assistance Project } \\
\text { (Loan \# 4245-BR) }\end{array}$ & 29/01/1998 & $\begin{array}{l}\text { 1. Development of a credit culture: }(a) \\
\text { availability of reliable information on potential } \\
\text { borrower (credit bureau data); }(b) \text { protections on } \\
\text { access to data. } \\
\text { 2. Suggesting improvements in legal protections } \\
\text { for credit contracts: }(a) \text { development of national } \\
\text { registries for property; }(b) \text { legal framework for } \\
\text { taking possession of collateral. }\end{array}$ & US\$ 20 milhões \\
\hline $\begin{array}{l}\text { First Programatic } \\
\text { Financial Sector } \\
\text { Adjustment Loan } \\
\text { (Loan \# 7053-BR) }\end{array}$ & $22 / 06 / 2001$ & $\begin{array}{l}\text { 1. Design of the intermediation efficiency and } \\
\text { access to financial services: formulation of a } \\
\text { strategy and action plans to further expand } \\
\text { financial services, including the use of movable } \\
\text { collateral to mobilize credit. } \\
\text { 2. Payment system reform and risk reduction. }{ }^{242}\end{array}$ & $\begin{array}{l}\text { US\$ 404,04 } \\
\text { milhões }\end{array}$ \\
\hline $\begin{array}{l}\text { Financial Sector } \\
\text { Technical } \\
\text { Assistance Project } \\
\text { (Loan \# 4637-BR) }\end{array}$ & $19 / 06 / 2002$ & $\begin{array}{l}\text { 1. Payment System risk reduction; } \\
\text { 2. Sectoral policy to enhance intermediation } \\
\text { efficiency; } \\
\text { 3. Reduction of intermediation spreads through } \\
\text { improved Risk Center. }\end{array}$ & $\begin{array}{l}\text { US\$ } 14,46 \\
\text { milhões }\end{array}$ \\
\hline $\begin{array}{l}\text { First } \\
\text { Programmatic } \\
\text { Adjustment Loan } \\
\text { for Sustainable } \\
\text { and Equitable }\end{array}$ & $21 / 06 / 2004$ & $\begin{array}{l}\text { 1. Improving the business environment: } \\
\text { replacing the existing bankruptcy regime; } 2 \text {. } \\
\text { Enhancing financial efficiency and } \\
\text { depth: better use of credit registries. }{ }^{245}\end{array}$ & $\begin{array}{l}\text { US\$ } 505,05 \\
\text { milhões }\end{array}$ \\
\hline
\end{tabular}

\footnotetext{
${ }^{241}$ Banco Mundial. Project Appraisal Document. Relatório n. 16867-BR, 23/10/1997, anexo 2, p. 2. Disponível em:

<http://web.worldbank.org/external/projects/main?pagePK=64283627\&piPK=73230\&theSitePK=40941\&menuP $\mathrm{K}=228424 \&$ Projectid=P048357>. Acesso em 15 dez. 2008.

${ }^{242}$ BANCO MuNDIAL. Implementation Completion and Results Report. Relatório n. 25116, 17/12/2002.

Disponível em:

< http://web.worldbank.org/external/projects/main?pagePK=64283627\&piPK=73230\&theSitePK=40941\&menuP $\mathrm{K}=228424$ \&Projectid=P070640>. Acesso em 15 dez. 2008.

${ }^{243}$ BANCO MUNDIAL. Implementation Completion and Results Report. Relatório n. ICR0000924, 06/11/2008, p.

9. Disponível em:

<http://web.worldbank.org/external/projects/main?pagePK=64283627\&piPK=73230\&theSitePK=40941\&menuP $\mathrm{K}=228424 \&$ Projectid=P073192>. Acesso em 15 dez. 2008.

${ }^{244}$ Sendo US\$ 8,2 milhões destinados para o BCB e o restante para a Comissão de Valores Mobiliários (CVM). Em dezembro de 2004, o BCB abriu mão dos valores não-sacados dos empréstimos. Assim, foram usados efetivamente até essa data US\$ 3,7 milhões dos US\$ 8,2 que seriam destinados ao BCB. A despeito de ter aberto mão do financiamento, continuou com o projeto de assessoria técnica. Cf. Banco Mundial. Implementation Completion and Results Report, 2008, p. 10.

${ }^{245}$ BANCO MUNDIAL. Implementation Completion and Results Report, Relatório, n. 32604, 28/06/2005.

Disponível em:

$<$ http://web.worldbank.org/external/projects/main?pagePK=64283627\&piPK=73230\&theSitePK=40941\&menuP $\mathrm{K}=228424$ \&Projectid=P080827 > . Acesso em 15 dez. 2008.
} 


\begin{tabular}{|c|c|c|c|}
\hline PROJETO & $\begin{array}{c}\text { DATA DA } \\
\text { ASSINATURA }\end{array}$ & ESCOPO PERTINENTE & $\begin{array}{c}\text { TOTAL } \\
\text { FINANCIADO }\end{array}$ \\
\hline \multicolumn{4}{|l|}{$\begin{array}{c}\text { Growth (Loan \# } \\
7218-\mathrm{BR})\end{array}$} \\
\hline $\begin{array}{c}\text { Sustainable and } \\
\text { Equitable Growth } \\
\text { Technical } \\
\text { Assistance Project } \\
\text { (Loan \# 7253-BR) }\end{array}$ & $04 / 10 / 2005$ & $\begin{array}{l}\text { 1. Improving the business environment: }(a) \\
\text { bankruptcy framework strengthened through } \\
\text { appropriate regulations and training } \\
\text { of judges and court personnel; }(b) \text { performance } \\
\text { assessment of judicial system in resolving } \\
\text { economic disputes in public and private sectors } \\
\text { completed. } \\
\text { 2. Enhancing efficiency and depth of the } \\
\text { financial system: diagnostic studies and action } \\
\text { plans prepared for reducing the cost of credit and } \\
\text { reducing financial spreads through studies on } \\
\text { financial system competition. }{ }^{246}\end{array}$ & $\begin{array}{c}\text { US\$ } 12,12 \\
\text { milhões }\end{array}$ \\
\hline
\end{tabular}

Fonte: Elaboração própria. Banco Mundial.

Como dito no capítulo 1, a perspectiva da dotação institucional influenciou o Banco Mundial e foi por ele influenciada. Dois sinais disso são: por um lado, a adoção, pelo BM, das metodologias prescritas pela literatura da Law and Finance para avaliação do ambiente de negócios em seu projeto Doing Business; por outro lado, o financiamento, pelo Banco Mundial, de muitos dos trabalhos realizados pelos teóricos da Law and Finance. ${ }^{247}$

Ao associar as reformas ao financiamento recebido do Banco Mundial, pretende-se apontar um ator relevante para a incorporação, no campo da prática jurídica, de concepções específicas oriundas da teoria econômica.

É plausível associar o financiamento de projetos de assessoria técnica à interferência sobre o conteúdo de medidas jurídicas em virtude de duas razões: primeiro, o enquadramento dos pedidos de financiamento às linhas financiáveis pelo Banco Mundial demanda, ainda que apenas no nível do discurso, a obediência a uma pauta específica de prioridades; e, segundo, a concessão de financiamento está declaradamente vinculada à implementação das estratégias

\footnotetext{
${ }^{246}$ B ANCO Mundial. Project Appraisal Document. Relatório n. 27987, 19/05/2004, p. 6. Disponível em: <http://web.worldbank.org/external/projects/main?pagePK=64283627\&piPK=73230\&theSitePK=40941\&menuP

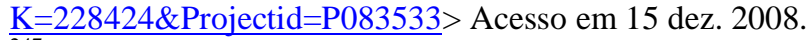

${ }^{247}$ Milhaupt e Pistor, Law and Capitalism, 2008, p. 20, nota 10, e p. 226.
} 
do BM, muito embora a instituição entenda que isso não se configure em interferência nos assuntos políticos dos países membros. ${ }^{248}$

A seguir são citadas e comentadas algumas passagens de documentos do Banco Mundial que mencionam as medidas de reforma do mercado de crédito que são objeto desta tese. Todos os trechos foram extraídos de relatórios de implementação de programas financiados durante o período de recorte desta pesquisa (1999-2006).

$\mathrm{O}$ excerto transcrito a seguir refere-se à criação da cédula de crédito bancário e à ampliação das possibilidades de uso da alienação e da cessão fiduciárias.

The government has [...] taken steps to improve the enforcement of credit contracts, which should help narrow loan spreads in the medium-term. It strengthened an existing contract (Alienação Fiduciária) that provides for the automatic transfer to the creditor of the property title on the collateral, which is held in a trust, if the debtor defaults. This facilitates the execution of guarantees and repossession of collateral where warranted. The government also created a new lending contract (Cédula de Crédito Bancário), which is a security that represents a bank credit - i.e., an assetbacked security where the underlying asset represented bank claims. It fulfills requirements to permit execution of title (título executivo), i.e., the underlying debt does not have to be recognized by a court. It also allows for securitization of the claim, which enables a more speedy enforcement of the creditor's rights, in the event of a default. $^{249}$

The introduction of several new legal instruments should improve contract enforcement and thus help to reduce default risk. The development of the Cédula de Crédito Bancário and the Alienação Fiduciária should contribute to increased lending by commercial banks at lower spreads, which will in turn induce higher economic growth, reduce poverty, and through better credit quality help prevent financial crises in the future. ${ }^{250}$

\footnotetext{
${ }^{248}$ ShinATA. I. The Role of Law in Business Development, Fordham International Law Review, n. 20, p. 15771588, 1996-1997.

${ }^{249}$ BANCO Mundial. Implementation Completion Report on a Loan No 7053-BR. 17 dez. 2002, p. 13. Tradução livre: "O governo [...] tomou medidas para aperfeiçoar os mecanismos de garantia do cumprimento de contratos de crédito, o que deve ajudar a reduzir o spread no médio prazo. Ele fortaleceu, ainda, um tipo de contrato que já existia (Alienação Fiduária), que estabelece a transferência automática ao credor do título de propriedade sobre o bem dado em garantia, que é mantido em confiança, para o caso de inadimplência. O governo também criou um novo contrato de empréstimo (Cédula de Crédito Bancário), que é um título representativo de um crédito bancário, isto é, um título de crédito garantido por bem que respalda dos direitos do banco. Esse contrato cumpre os requisitos para a execução por título executivo extrajudicial, isto é, não há necessidade de que o débito subjacente seja reconhecido em juízo. Ele também permite a securitização do direito, o que permite uma satisfação mais célere dos direitos do credor em caso de inadimplemento."

${ }^{250}$ Banco Mundial, Implementation Completion Report on a Loan $N^{o} 7053-B R, 2002$, p. 14. Tradução livre: "A introdução de vários instrumentos jurídicos novos deve melhorar a garantia de cumprimento de contratos e, assim, ajudar a reduzir o risco de inadimplemento. O desenvolvimento da Cédula de Crédito Bancário e da
} 
Em linha com os documentos do PJSB, essas medidas são relacionadas à diminuição das taxas de intermediação financeira. Note-se que a diminuição do spread bancário é associada não só a crescimento econômico sustentado, mas também à redução da pobreza. Esse tipo de argumentação não é comum nos relatórios do PJSB, mas é recorrente no documento RMCLP. O RMCLP, na verdade, já reflete o alargamento da noção de desenvolvimento adotada pelo Banco Mundial a partir de 1999, na gestão do presidente James Wolfensohn. Em reação às críticas endereçadas às reformas realizadas com base no Consenso de Washington, Wolfensohn passou a advogar uma visão mais abrangente de desenvolvimento e por uma nova estratégia de implementação de reformas financiadas pelo BM. Assim, a erradicação da pobreza e o aumento de oportunidades para a população de baixa renda passaram a estar no foco das preocupações do Banco Mundial e, quanto à estratégia, o envolvimento de interessados locais (stakeholders) passa a ser visto como imprescindível para a construção de reformas consistentes e sustentáveis no longo prazo. Essa noção alargada de desenvolvimento é referida como desenvolvimento inclusivo (comprehensive development). ${ }^{251}$

Ao aproximar a intervenção econômica dos benefícios sociais por ela supostamente gerados, o discurso do Banco Mundial faz com que oposições às reformas pretendidas possam ser qualificadas como impeditivas de avanços sociais relevantes, o que tende a contribuir para a despolitização dos processos de implementação dessas medidas nos espaços jurídicos nacionais.

No mesmo sentido, é desqualificada a intervenção judicial na discussão de assuntos relacionados ao crédito, valorizando-se mecanismos que subtraem ao exame do judiciário a discussão sobre o conteúdo de contratos, uma vez que tal subtração é vista como meio para aumentar a previsibilidade, diminuindo tanto o risco de crédito como a possibilidade de uso estratégico do judiciário para protelar o pagamento de dívidas. ${ }^{252}$

\footnotetext{
Alienação Fiduciária deve contribuir para a ampliação de empréstimos com spread mais baixo por parte dos bancos comerciais, o que, por sua vez, irá gerar maior crescimento econômico, reduzir a pobreza e, por meio de melhor qualidade de crédito, ajudar a evitar crises financeiras no futuro."

${ }^{251}$ A respeito, confira www.worldbank.org/cdf.

${ }^{252}$ A esse respeito, cf. capítulo 2, seção 2.1 e 2.6.
} 
A chamada Reforma Infraconstitucional do Processo, também mencionada em um relatório de implementação do Banco Mundial, segue na mesma esteira. Associa as medidas propostas pelo Governo Federal como aptas a promover a melhoria de regras processuais, especialmente ao prever a diminuição de procedimentos para se fazer valer contratos, buscando aproximar o tempo do processo ao tempo econômico:

\begin{abstract}
Significant initiatives for the reform of the judiciary, an area in which the government originally had lower expectations, were also undertaken with government sponsoring several bills of Law to improve procedural issues and support alternative dispute resolutions mechanisms. [...] These include: (i) procedural reform in court ruling (Bill of Law 52/2004); (ii) procedural reform for out-of court securities settlements (Bill of Law 4,497/2004); and (iii) other projects of reform of the Civil-Law Code of Procedures [(a) Bill of Law 4,724/2004, (b) Bill of Law 4,728/2004, (c) Bill of Law 4,726/2004, (d) Bill of Law 4,727/2004, (e) Bill of Law 4,729/2004, (f) Bill of Law 4,725/2004 and (g) Bill of Law 4,723/2004)]. ${ }^{253}$
\end{abstract}

Quanto à tramitação do Projeto de Lei que alteraria, em 2005, o regime falimentar brasileiro, diz o Banco Mundial:

[...] creditor rights would be further clarified and their enforcement further improved if and when the Congress approves the recently submitted amendments to the Bankruptcy and Reorganization Law (Lei de Falência). Even after the submission of the present draft to Congress, Bank inputs have been valuable in proposing further modifications to the proposed draft law. Nevertheless, progress on passage of the new Law has been slow. ${ }^{254}$

Nesse documento, é possível perceber que o trâmite de negociação política no

\footnotetext{
253 BANCO Mundial. Implementation Completion and Results Report, 2005, p. 8. Os PL aprovados pelo Congresso Nacional são comentados no capítulo 2, na seção 2.6. Tradução livre: "Iniciativas importantes de reforma do Judiciário, uma área em que o governo tinha inicialmente expectativas reduzidas, também foram realizadas por meio de apoio governamental a vários projetos de lei para melhorar aspectos processuais e para apoiar o uso de mecanismos alternativos de resolução de disputas. [...] Essas medidas incluem (i) reforma de mecanismos processuais de decisão do magistrado (PL 52/2004); (ii) reforma de mecanismos processuais de acordos extrajudiciais de execução de garantias (PL 4.497/2004); e (iii) outros projetos de reforma do Código de Processo Civil [(a) PL 4.724/2004, (b) PL 4.728/2004, (c) PL 4.726/2004, (d) PL 4.727/2004, (e) PL 4.729/2004, (f) PL 4.725/2004 e (g) PL 4.723/2004]."

${ }^{254}$ Banco Mundial, Implementation Completion Report on a Loan No 7053-BR, 2002, p. 13. Tradução livre: "[...] os direitos do credor ficarão mais claros e sua garantia mais reforçada se e quando o Congresso aprovar as emendas à Lei de Falência recentemente apresentadas. Mesmo após a apresentação dessas emendas, a participação dos bancos tem sido valiosa na sugestão de modificações adicionais ao atual projeto. O progresso no processo de aprovação da nova lei, entretanto, tem sido lento."
} 
Congresso é visto como um obstáculo, seja pela demora, seja pela interferência no conteúdo, que pode desconsiderar as melhores práticas internacionais. Nessa linha, o processo legislativo será tão melhor quanto mais célere, e seu resultado tão mais eficiente, quanto mais alinhado com as práticas testadas e aprovadas pelo mundo afora:

The reform of the bankruptcy laws in Brazil was concluded with Law 11,101/2005 and Complementary Law 118/2005. The latter legal instrument made changes to the dispositions of the National Tax Code and is considered one of the most important measures for the improvement of the business environment. These two laws align the legislation concerning bankruptcy in Brazil with international practices. ${ }^{255}$

Não surpreendem, assim, as medidas de "conscientização",256 que buscam pautar tecnicamente a ação de juízes e advogados:

To disseminate the new bankruptcy law within the legal profession, among other initiatives to be undertaken within the Growth Program, a technical assistance loan associated with the loan was contracted within the scope of a Support Program to the Agenda of Equitable and Sustainable Economic Growth (PACE). A series of training and professional improvement courses were offered to judges and attorneys general with the objective of the effective implementation of the bankruptcy law. ${ }^{257}$

Assim, juízes e advogados devem ser preparados para aplicar "corretamente" a lei, tendo em conta a sua lógica econômica, o que sugere que interpretações dissonantes sejam vistas como equivocadas.

No mesmo relatório, são mencionadas, ainda, as medidas de implementação do novo Sistema de Pagamentos Brasileiro. Não é feita referência expressa à possibilidade de realizarem-se acordos de compensação de pagamentos, mas é mencionado que o novo sistema

\footnotetext{
255 BANCO MundiAL, Implementation Completion and Results Report, 2005, p. 14. Tradução livre: "A reforma da legislação sobre falência no Brasil foi concluída por meio da Lei 11.101/2005 e da Lei Complementar 118/2005. Esse último instrumento legal introduziu mudanças no Código Tributário Nacional e é considerado uma das medidas mais importantes para a melhoria do ambiente para negócios. Essas duas leis alinham a legislação sobre falência no Brasil às práticas internacionais."

${ }^{256}$ O termo "conscientização" é empregado pelo PJSB. Cf. BCB, Economia bancária e crédito, 2003, p. 31, e 2004 , p. 45.

257 BANCO Mundial, Implementation Completion and Results Report, 2005, p. 15. Tradução livre: "Para disseminar a nova legislação sobre falência entre as profissões jurídicas, além de outras iniciativas tomadas dentro do Programa de Crescimento, foi contraído um empréstimo de assistência técnica dentro do escopo do Programa de Apoio à Agenda de Crescimento Econômico Equitativo e Sustentável (PACE). Foram oferecidos diversos cursos de treinamento e de aperfeiçoamento profissional para juízes e procuradores-gerais com o objetivo da efetiva implementação da legislação sobre falência."
} 
atende às melhores práticas internacionais. ${ }^{258} \mathrm{~A}$ compensação de pagamentos é referida como boa prática no décimo-quarto princípio do documento Principles and Guidelines for Effective Insolvency and Creditor Rights Systems, elaborado pelo Banco Mundial. ${ }^{259}$

Sobre a consignação de pagamentos em folha de pagamento de empregados celetistas e de aposentados e pensionistas do INSS, diz o Banco Mundial:

\begin{abstract}
The introduction of the loan modality that allows loan installments to be directly deducted from employees' pay checks (Law N. ${ }^{\circ} 10.820 / 2003$ and Law N. ${ }^{\circ}$ $10.953 / 2004)$ will increase access to credit and reduce costs. This new credit modality has a smaller risk. As a result, it has become one of the credit operations that offer the market's lowest rates. [...] The development of this modality helped demonstrate the important role played by low risks of loan delinquency, and of the legal security of operations toward making credit cheaper and increasing access to it - a fact that especially benefits low-income populations. ${ }^{260}$
\end{abstract}

A lógica que rege a garantia do crédito se vê justificada em grande parte pelo seu impacto social em benefício da população de baixa renda. Essa lógica discursiva remete à mesma argumentação já referida quando se tratou da Lei de Falências: opiniões em contrário à consignação são tomadas como resistências à extensão de benefícios sociais para a população de baixa renda.

Nesses relatórios de implementação elaborados pelo Banco Mundial são citadas, também, outras iniciativas do Governo Federal que não ainda foram transformadas em lei. Essas iniciativas também coincidem com as medidas propostas pelos documentos do PJSB.

\footnotetext{
${ }^{258}$ ICR 7218, p. 18.

${ }^{259}$ Banco Mundial, Principles and guidelines for effective insolvency and creditor rights systems, 2001, p. 36-39.

${ }^{260}$ ICR 7218, p. 15-6. Tradução livre: “A introdução da modalidade de empréstimo que permite que parcelas do empréstimo sejam deduzidas diretamente do salário do empregado (Lei N. ${ }^{\circ}$ 10.820/2003 e Lei N. ${ }^{\circ}$ 10.953/2004) aumentará o acesso ao crédito e reduzirá custos. Essa nova modalidade de crédito apresenta risco menor. Como resultado, tornou-se uma das operações de crédito que oferece as menores taxas do mercado. [...] $\mathrm{O}$ desenvolvimento dessa modalidade ajudou a demonstrar a relevância do papel desempenhado pelos baixos riscos de inadimplência e pela segurança jurídica das operações no sentido de baratear o crédito e aumentar o acesso um fato que beneficia especialmente as populações de baixa renda."
} 


\section{$3.2 \mathrm{O}$ direito da dotação institucional: considerações metodológicas}

No capítulo 1, foi descrito o método de pesquisa de que a literatura da Law and Finance valeu-se em seus estudos comparativos. Esta seção examina alguns aspectos desse método. São eles: $(a)$ a categorização das tradições jurídicas; $(b)$ o suporte das conclusões pela estratégia de pesquisa empregada; (c) variáveis: escolhas, escalas e ponderações; e $(d)$ respondentes: referência comum e verificação da informação prestada.

A perspectiva da dotação institucional associa o grau de desenvolvimento econômico ao nível de proteção dos direitos de credores e acionistas, que, por sua vez, varia conforme a tradição jurídica da qual deriva o ordenamento jurídico nacional em análise. A linha causal com esses três elementos relevantes para a dotação institucional poderia ser esquematizada assim:

Tipo de tradição jurídica
Nível de proteção

a credores e acionistas
Grau de

crescimento

econômico

Para testar empiricamente essa associação, são tomadas como variáveis algumas regras jurídicas vigentes em alguns países desenvolvidos. Verifica-se, então, país a país da amostra, a existência ou não de correspondentes nos ordenamentos jurídicos nacionais. Valendo-se de uma lógica circular, a perspectiva da dotação institucional sugere que as regras de proteção dos direitos de credores e acionistas são as mais encorajadoras do crescimento econômico justamente por terem sido recolhidas em países desenvolvidos. ${ }^{261}$ Num misto de descrição e de

\footnotetext{
${ }^{261}$ Milhaupt e Pistor, Law and Capitalism, 2008, p. 202.
} 
prescrição, essas regras são assumidas como best practices autoevidentes capazes de conduzir países não desenvolvidos para o caminho do desenvolvimento econômico, que passa pela convergência institucional. ${ }^{262}$

Como visto, a literatura da Law and Finance associa o nível de proteção dos credores à família jurídica da qual cada ordenamento jurídico nacional é derivado. É assumida, assim, uma categorização ampla, que divide o mundo em dois grandes grupos: os países de common law e os de civil law. Esses últimos são subdivididos em sistemas de origem francesa, germânica ou nórdica.

Na divisão dos países conforme a sua origem jurídica, é feita uma caricatura dos sistemas jurídicos, como se houvesse, por exemplo, discricionariedade plena dos juízes da common law e vinculação absoluta do juízes da civil law à lei. Por essa visão, o desenvolvimento do direito que propulsiona o crescimento econômico nos países de common law caberia precipuamente aos tribunais, ${ }^{263}$ pois seus juízes teriam condições institucionais de captar demandas do mundo econômico. Já na civil law, os juízes estariam mais jungidos à lei, como se a aplicação do direito nesses países fosse uma operação de natureza silogística, tal como aventada pelos codificadores do direito privado na França do fim do século XVIII e início do século XIX.

Naquele período, em reação às experiências da administração da justiça durante o Antigo Regime, pretendia-se aproximar o direito de um sistema dedutivo, ligando o ato de aplicar a norma ao caso concreto a uma operação de natureza impessoal. ${ }^{264}$ Feito isso, não caberia nenhuma função criadora ao juiz e estaria garantida a completa separação entre a função e o homem que a ocupa:

Uma vez estabelecidos os fatos, bastava formular o silogismo judiciário, cuja [premissa] maior deveria ser fornecida pela regra de direito apropriada, a [premissa]

\footnotetext{
${ }^{262}$ RITTICH, K. Recharacterizing Restructuring: Law, Distribution and Gender in Market Reform. Boston: Kluwer Law International, 2002, p. 85.

${ }^{263}$ Ver canal da adaptabilidade, capítulo 1, seção XXX.

${ }^{264}$ PeRelman, C. Lógica jurídica: nova retórica. São Paulo: Martins Fontes, 1998, p. 32-33.
} 
menor pela constatação de que as condições previstas na regra haviam sido preenchidas, sendo a decisão dada pela conclusão do silogismo. ${ }^{265}$

Tal postura do juiz pressupunha a existência de um sistema de direito completo e coerente, que servisse de manancial inesgotável e infalível de premissas para a aplicação do direito. Ao juiz caberia exclusivamente a verificação dos fatos e a sua subsunção aos ditames da lei, que já vinham prontos do parlamento em um sistema lógico. ${ }^{266}$

A Law and Finance caracteriza os países de civil law como se a forma de aplicação do direito atendesse a esse modelo silogístico e não fosse possível nenhuma forma de inovação da ordem jurídica pela jurisprudência. Teubner e Pistor, por exemplo, mostraram que o princípio da boa-fé nos contratos comerciais é um produto exemplar de desenvolvimento jurisprudencial dos países de civil law. ${ }^{267}$

De outro lado, boa parte do direito comercial dos países de common law, a exemplo do que se dá nos países de civil law, não é produto de case law, mas sim de leis ou códigos. ${ }^{268}$ Do direito inglês, considere-se as várias edições do Companies Act, promulgadas pelo Parlamento desde 1844 até a sua versão mais recente, de $2006 .{ }^{269}$ Pense-se, ainda, no Sherman Antitrust Act, de 1890, no Clayton Antitrust Act, de 1914, no Uniform Commercial Code, cuja primeira edição é de 1952, e na Sarbanes-Oxley Act, de 2002: são quatro exemplos de legislação comercial, colhidos aleatoriamente, do direito dos EUA.

Além disso, será que ainda é possível dividir tão nitidamente os ordenamentos jurídicos em tradições de direito, considerando que a maioria deles contém elementos híbridos

\footnotetext{
${ }^{265}$ Perelman, Lógica jurídica: nova retórica, 1998, p. 33.

${ }^{266}$ Perelman, Lógica jurídica: nova retórica, 1998, p. 34-35. A respeito da escola da exegese, veja ainda BOBBIO, N. O positivismo jurídico: lições de Filosofia do Direito. São Paulo: Ícone, 1995, p. 78-89.

${ }^{267}$ Cf. TeUbner, G. Legal Irritants: How Unifying Law Ends Up in New Divergences. In: HALL, P. and SosKICE, D. (eds.) Varieties of Capitalism. Oxford: Oxford University, 2001, p. 417-442; e PISTOR, K. Legal Ground Rules in Coordinated and Liberal Market Economies. ECGI Law Working Paper n. 30, 2005.

${ }^{268}$ Armour, Deakin, Sarkar, Siems e Singh, Shareholder Protection and Stock Market Development, 2008;

FUNKEN, K. The best of both worlds: the trend towards convergence of the civil law and the common law system. Working paper, University of Munich School of Law, 2003; J. ARMOUR, J. Codification and UK Company Law. Disponível em: http://www1.fee.uva.nl/fm/conference/legal/2008\%20Company\%20Law\%20Codification\%20Dalloz.pdf. Acesso em: 15 dez. 2008.

${ }^{269}$ Para uma análise da relação entre o Company Act e a codificação do direito privado na França, cf. Armour, Codification and UK Company Law, 2008.
} 
da common law, da civil law e possivelmente de outras fontes? $?^{270}$ E mesmo entre os países tidos como de civil law, qual a diferença específica que justifica a classificação em (i) civil law francesa, (ii) civil law germânica e (iii) civil law nórdica?

Outra dimensão a ser considerada é a pertinência dos meios de pesquisa às hipóteses a serem testadas. Dentre os vários métodos de pesquisa observacional, é relevante mencionar nesta seção duas espécies: as pesquisas de corte transversal e as de corte longitudinal. As pesquisas de corte transversal observam uma ou mais variáveis em um mesmo ponto do tempo; já as de corte longitudinal observam o comportamento de uma ou mais variáveis em diferentes momentos, demandando a realização de uma série de medições ao longo do tempo. $^{271}$

A literatura da Law and Finance vale-se principalmente de pesquisas de corte transversal, apoiadas em dados colhidos quase exclusivamente na década de $1990 .{ }^{272}$ Muito provavelmente, essa opção metodológica deu-se em razão da falta de séries temporais que permitissem uma pesquisa de corte longitudinal, mais apropriada para testar as hipóteses cogitadas por essa literatura. ${ }^{273}$ Por isso, é questionável extrair conclusões sobre esse tipo de relação baseado apenas em dados de um mesmo ponto no tempo, como se o direito estivesse estacionado na década de $1990 .^{274}$

Há uma grande distância entre assumir que o direito atual é fortemente determinado pela origem jurídica (path-dependence) e tomar o direito como algo estático. Ainda que restrito por escolhas pretéritas, path-dependence sugere movimento. E isso não é ignorado nas passagens em que essa literatura trata dos mecanismos de influência das origens jurídicas

\footnotetext{
${ }^{270}$ Armour, Deakin, Sarkar, Siems e Singh, Shareholder Protection and Stock Market Development, 2008, p. 4; SIEMS, M. Reconciling Law \& Finance and comparative law, McGill Law Journal, 52, 2007, p. 55-81.

${ }^{271}$ HernándeZ SAMPIERI, R.; FERnÁNDEZ COllado, C.; BAPTISTA LuCIO, P. Metodologia de pesquisa. 3. ed. São Paulo: McGraw-Hill, 2006, 744 p.

${ }^{272}$ Armour, Deakin, Sarkar, Siems e Singh, Shareholder Protection and Stock Market Development, 2008, p. 6-7; Milhaupt e Pistor, Law and Capitalism, 2008, p. 23-25. Uma exceção importante é Rajan e Zingales, comentada a seguir.

${ }^{273}$ Armour, Deakin, Sarkar, Siems e Singh, Shareholder Protection and Stock Market Development, 2008, p. 8.

${ }^{274}$ Armour, Deakin, Sarkar, Siems e Singh, Shareholder Protection and Stock Market Development, 2008, p.8; Milhaupt e Pistor, Law and Capitalism, 2008, p. 23.
} 
sobre o direito e a economia. ${ }^{275}$ Porém, os testes empíricos se restringem a confrontar regras previstas por diversos ordenamentos jurídicos nacionais com um modelo de direito, tido como o mais apto a fomentar a expansão econômica.

Assumindo que o direito desempenha um papel central no desenvolvimento econômico, caso haja diferença entre os efeitos de longo prazo de uma mudança jurídica e seus efeitos de curto prazo, a mensuração da influência das regras jurídicas sobre a economia pode variar significativamente. ${ }^{276}$ Para contornar esse problema potencial, o melhor seria lançar mão de pesquisas de corte longitudinal, que poderiam cotejar a história das instituições jurídicas com os níveis de desenvolvimento econômico de um país ao longo do tempo. ${ }^{277}$

Adotando uma estratégia de pesquisa de corte longitudinal, um estudo de Rajan e Zingales, por exemplo, reúne dados de desenvolvimento do mercado de capitais de vários países para o período de 1913 a 1999. Esses dados permitem observar que o mercado de capitais francês, antes da Segunda Guerra Mundial, era muito mais desenvolvido que o dos EUA. Ao longo da segunda metade do século XX, contudo, essa situação se inverteu, a despeito de a variável tradição jurídica ter permanecido constante. ${ }^{278}$

Os textos da Law and Finance referidos por esta tese também não explicitam o processo de seleção das variáveis. Nas análises sobre eficiência dos sistemas de enforcement de contratos - que se baseia em dados de custo, de tempo e de procedimentos em ações simuladas de cobrança de um cheque sem fundos e de despejo por falta de pagamento - não fica claro se algumas regras foram ou não levadas em conta. Davis e Kruse mencionam o papel desempenhado pelo direito penal na cobrança de dívidas de alguns países. ${ }^{279}$ Dos textos da Law and Finance, não é possível depreender se esse tipo de regra é considerado ou não. É

\footnotetext{
${ }^{275}$ Sobre os mecanismos, cf. seção 1.3.3.

${ }^{276}$ DAvis, K.; KruSE, M. Taking the Measure of Law: The Case of the Doing Business Project, Law \& Social Inquiry, v. 32, n. 4, 2007, p. 1113-1114.

277 Armour, Deakin, Sarkar, Siems e Singh, Shareholder Protection and Stock Market Development, 2008, p. 910.

${ }^{278}$ RajAN, R.; ZINGALES, L. The Great Reversals: The Politics of Financial Development in the Twentieth Century, Journal of Financial Economics, n. 69, p. 5-50, 2003. O nível de desenvolvimento do mercado de capitais ao longo do século XX foi calculado pela razão entre o valor de mercado das ações das companhias nacionais listadas em bolsa e o Produto Interno Bruto do país.

${ }^{279}$ Davis e Kruse, Taking the Measure of Law, 2007, p.1112.
} 
possível imaginar que as regras processuais são menos relevantes para o enforcement de contratos nos países em que a persecução penal do devedor é prevista pelo ordenamento jurídico. ${ }^{280}$ Assim, poder-se-ia concluir que as regras processuais são relevantes apenas em alguns países, o que colocaria em xeque a possibilidade de raciocínio do one size fits all (tamanho único). ${ }^{281}$

Ao analisar as regras de governança corporativa valorizadas pela Law and Finance, Armour et. al. falam em viés na seleção das variáveis, que espelhariam a realidade jurídica dos EUA $^{282}$. Não são dadas justificativas quanto ao fato de se considerar relevantes determinadas regras de proteção dos direitos dos credores e outras não.

Do mesmo modo, não são dados esclarecimentos suficientes sobre o peso atribuído às variáveis e aos índices que as congregam. ${ }^{283}$ Regras de proteção dos direitos dos credores têm a mesma relevância que o nível de enforcement?

Há que se considerar também que não é levada em conta a possibilidade de uma determinada variável desempenhar funções diferentes em diferentes países, nem a possibilidade de variáveis diferentes desempenharem o papel que é esperado da variável selecionada. ${ }^{284}$ Além disso, a importância relativa de uma variável para o desenvolvimento pode mudar de um contexto para outro, e isso pode ser refletido na percepção do respondente da pesquisa. ${ }^{285} \mathrm{O}$ tempo para a recuperação de um crédito via poder judiciário pode ser, segundo Davis e Kruse, mais relevante para um país que não conta com consolidados mecanismos alternativos de solução de disputas. ${ }^{286}$

\footnotetext{
${ }^{280}$ Davis e Kruse, Taking the Measure of Law, 2007, p.1112.

${ }^{281}$ Davis e Kruse, Taking the Measure of Law, 2007, p.1112.

${ }^{282}$ Armour, Deakin, Sarkar, Siems e Singh, Shareholder Protection and Stock Market Development, 2008, p. 7. Também sobre o possível viés de seleção, cf. Davis e Kruse, Taking the Measure of Law, 2007, p. 1097 e 1110.

${ }^{283}$ Armour, Deakin, Sarkar, Siems e Singh, Shareholder Protection and Stock Market Development, 2008, p. 7.

${ }^{284}$ Armour, Deakin, Sarkar, Siems e Singh, Shareholder Protection and Stock Market Development, 2008 , p. 8.

${ }^{285}$ Armour, Deakin, Sarkar, Siems e Singh, Shareholder Protection and Stock Market Development, 2008, p. 8; e Davis e Kruse, Taking the Measure of Law, 2007, p. 1109-1110.

${ }^{286}$ Davis e Kruse, Taking the Measure of Law, 2007, p. 1110. Nesse artigo, a hipótese é apenas cogitada como plausível. Não é testada empiricamente.
} 
Ainda em relação ao contexto, não é ponto pacífico assumir que o volume de crédito concedido seja necessariamente um indicador seguro de desenvolvimento financeiro. ${ }^{287}$ Não é feita nenhuma ressalva sobre a possibilidade, por exemplo, de crescimento não-sustentado do mercado de crédito, apoiado em bolhas especulativas. ${ }^{288}$

Tendo em conta a realidade a ser mensurada por essas pesquisas, por que usar como medida da prosperidade de um país o Produto Nacional Bruto ou o Produto Nacional Bruto per capita? Nenhuma justificativa é apresentada para o uso dessas variáveis em vez de outras. Nesse caso, poder-se-ia cogitar, por exemplo, o uso da paridade de poder de compra (PPC) como indicador. ${ }^{289}$ Apesar das dificuldades para estabelecer uma correspondência internacional de bens de consumo, esse indicador consideraria não só diferenças de renda per capita, como também diferenças no custo de vida. ${ }^{290}$

Ademais, não há medidas de controle da incerteza sobre as informações, gerada, por exemplo, por eventual desconhecimento do respondente da survey ou pela falta de uma referência comum para os respondentes. ${ }^{291}$ A escala binária para as respostas, em esquema de tudo ou nada, também não contribui para matizações exigidas, por exemplo, para regras aplicadas somente em certas circunstâncias e não de modo mandatório, em todas as ocasiões. $^{292}$

Considerando que essas limitações metodológicas possam comprometer os resultados das investigações realizadas, alguns estudos estão verificando as conclusões da Law and Finance, valendo-se dos mesmos meios ou de estratégias distintas de pesquisa.

Apenas para aferir a exatidão dos dados levantados por um dos trabalhos mais difundidos da Law and Finance, ${ }^{293}$ Spamann, por exemplo, refez parte da pesquisa

\footnotetext{
${ }^{287}$ Davis e Kruse, Taking the Measure of Law, 2007, p. 1110.

${ }^{288}$ Davis e Kruse, Taking the Measure of Law, 2007, p. 1110.

${ }^{289}$ Davis e Kruse, Taking the Measure of Law, 2007, p. 1110.

${ }^{290}$ Wikipédia, verbete "Paridade de poder de compra". Cf. http://pt.wikipedia.org/wiki/Paridade_do_poder_de_compra.

${ }^{291}$ Davis e Kruse, Taking the Measure of Law, 2007, p. 1105.

${ }^{292}$ Armour, Deakin, Sarkar, Siems e Singh, Shareholder Protection and Stock Market Development, 2008 , p. 7.

${ }^{293}$ La Porta et al, Law and Finance, 1998.
} 
empreendida por La Porta et al. e obteve resultados diferentes, que não suportam a hipótese das tradições jurídicas. Como o intuito de Spamann não era contestar as opções metodológicas de La Porta et al., ele simplesmente repetiu a coleta de dados para um mesmo conjunto de indicadores, com diferentes formas de controle da informação prestada pelos respondentes dos questionários. Ao final, dos 46 países pesquisados por Spamann, 33 apresentaram resultados diferentes daqueles levantados por La Porta et al.. ${ }^{294}$

Já Armour et. al., criticando o fato de os estudos pioneiros da Law and Finance não considerarem o cumprimento do direito na prática, lançam mão de pesquisa voltada para apreciar a aplicabilidade efetiva de regras de direito societário pelos tribunais dos EUA e do Reino Unido. ${ }^{295}$ Para os fins desta tese, o que é relevante mencionar desse estudo é o fato de ele voltar-se não só para as instituições formais de administração da justiça, mas considerar também o que se poderia chamar de mecanismos informais de cumprimento do direito, como é o caso do Takeover Panel inglês, mencionado adiante.

Por fim, vale citar, ainda, os autonomeados estudos "leximétricos" publicados pelo Centre for Business Research da Universidade de Cambridge. ${ }^{296}$ Assim como os teóricos da Law and Finance, esses estudos supõem que as regras jurídicas podem ser medidas e comparadas entre países. Porém, por identificarem limites nos índices usados pela Law and Finance, eles propõem variações nos métodos empregados. Nesses estudos, em regra, (a) o corte para a coleta de dados é longitudinal; $(b)$ as escalas de medição da correspondência entre a variável e o direito pesquisado permitem gradação, fugindo do sistema binário, que força a

\footnotetext{
${ }^{294}$ SpamanN, H. 'Law and Finance' Revisited. fev. 2008. Harvard Law School John M. Olin Center for Law, Economics, and Business Discussion Paper n. 12. Disponível em: http://ssrn.com/abstract=1095526. Acesso em 15 dez. 2008. Originalmente, LA PORTA et al., Law and Finance, colheram dados de 49 países. Spamann deixou de colher dados da Indonésia, do Sri Lanka e do Zimbábue. A respeito disso especificamente, cf. p. 5.

${ }^{295}$ ARMOUR, J.; BLACK, B.; CHEFFINS, B.; NOLAN, R. Private Enforcement of Corporate Law: An

Empirical Comparison of the US and UK, European Corporate Governance Institute Working Paper, 2007.

Disponível em: http://www.ecgi.org/competitions/rof/files/UK US corp law enforcement draft ECGI.pdf. Acesso em 15 dez. 2008.

${ }^{296}$ Dentre outros: FAgERnÄs, S.; SARKAR, P.; SINGH, A. Legal Origin, Shareholder Protection, and the Stock Market: New Challenges from Time Series Analysis. Centre for Business Research, University of Cambridge, Working Paper 343, jun. 2007. Disponível em: http://www.cbr.cam.ac.uk/pdf/WP343.pdf; LELE, P.; SIEMS, M. Shareholder Protection: A Leximetric Approach, Journal of Corporate Law Studies, n. 7, p. 17-50, 2007; SIEMS, M. Shareholder Protection Around the World ("Leximetric II"), Delaware Journal of Corporate Law, n. 33, p. 111-147, 2008; Armour, Deakin, Sarkar, Siems e Singh, Shareholder Protection and Stock Market Development, 2008. O termo "leximetria" foi cunhado em referência à econometria.
} 
escolha entre o tudo e o nada; e (c) o número de variáveis consideradas é mais amplo. ${ }^{297} \mathrm{Em}$ um dos estudos, por exemplo, chega a sessenta. ${ }^{298}$ Para a pesquisa do mesmo tema, La Porta et al. usam dez variáveis. ${ }^{299}$ Essas pesquisas lexicométricas também ampliam o tipo de direito investigado, considerando, além disso, códigos de autorregulação e regras informais que têm poder vinculante de facto. O tipo de direito considerado pela perspectiva da dotação institucional é um dos temas da seção seguinte.

\subsection{O direito da dotação institucional: pressupostos teóricos}

Os parágrafos que seguem buscam identificar a concepção de direito da dotação institucional, a ser apreendida pela identificação de algumas premissas teóricas sobre $(a)$ a vinculação entre direito e economia, $(b)$ a relação entre direito e política e $(c)$ a própria função do direito.

Conforme exposto no capítulo 1, o direito na perspectiva da dotação institucional é tido como uma plataforma sólida que, devidamente assentada, serve de alicerce para o crescimento econômico. ${ }^{300}$ Nessa visão, podem ser identificados dois pressupostos sobre a relação entre direito e economia: um sobre $(i)$ a própria natureza da relação entre os dois campos e outro sobre (ii) a posição do sistema jurídico em face dos mercados.

Pode-se dizer que a relação pressuposta entre regras jurídicas e mercado é de causalidade unidirecional, do direito para a economia. ${ }^{301}$ É uma determinada configuração do direito que possibilita o desenvolvimento da atividade econômica. Uma vez alcançada essa configuração, o direito deixa de ser uma preocupação e o crescimento econômico dá-se como decorrência natural de uma base jurídica bem construída. Daí falar-se em direito como uma dotação fixa.

\footnotetext{
${ }^{297}$ Armour, Deakin, Sarkar, Siems e Singh, Shareholder Protection and Stock Market Development, 2008, p. 910.

${ }^{298}$ Armour, Deakin, Sarkar, Siems e Singh, Shareholder Protection and Stock Market Development, 2008, p. 10.

${ }^{299}$ La Porta et al, Law and Finance, 1998, p. 1122-1124.

${ }^{300}$ Cf. seção 1.3 .

${ }^{301}$ Milhaupt e Pistor, Law and Capitalism, 2008, p. 21.
} 
Intimamente ligada à natureza da relação pressuposta entre direito e economia está a posição do sistema jurídico em face dos mercados. Na perspectiva da dotação institucional, o direito é um fator exógeno ao funcionamento dos mercados. Ele é dado previamente e não interage com as variáveis endógenas tidas como relevantes para o crescimento econômico.

Dessa forma, não se imagina uma influência recíproca entre direito e mercado. Dada determinada infraestrutura jurídica, ter-se-á crescimento econômico. Ou seja, uma vez assentada a base jurídica, o direito passa a ser um dado, desconsiderando-se qualquer forma de interação dinâmica entre direito e economia ou possíveis ações e reações estratégicas dos atores e instituições envolvidos em ambos os sistemas. ${ }^{302} \mathrm{O}$ crescimento econômico, assim, é visto como consequência natural de um sistema jurídico bem estruturado.

Conforme essa lógica, o critério para avaliar o que é uma base jurídica bem estruturada é sua capacidade de fomentar o crescimento econômico. Mirando-se nos ordenamentos jurídicos de países desenvolvidos, a perspectiva da dotação institucional sugere que um bom sistema jurídico é aquele que conta com direitos de propriedade bem definidos e com mecanismos eficientes para fazer valer a lei e os contratos.

Ao mesmo tempo em que coloca o direito no centro do debate sobre desenvolvimento econômico, essa perspectiva paradoxalmente reduz o seu escopo ao reconhecer como relevante para o mercado apenas o seu papel de definidor e protetor de determinados direitos.

Segundo a perspectiva da dotação institucional, o papel a ser desempenhado pelo direito em função do mercado está atrelado exclusivamente à clara definição e à proteção de direitos de propriedade, pois direitos de propriedade bem definidos - que incluem os direitos dos credores - e mecanismos eficientes para fazer valer a lei e os contratos são precondições para o sucesso econômico de qualquer país. ${ }^{303}$ Do direito não é esperada outra função que não essa meramente protetora. Sem dúvida, esse papel de proteção é fundamental, especialmente

\footnotetext{
${ }^{302}$ Milhaupt e Pistor, Law and Capitalism, 2008, p. 6.

${ }^{303}$ Milhaupt e Pistor, Law and Capitalism, 2008, p. 7 e 31.
} 
quando se pensa em poupança e em investimento. Porém, não é a única função que pode ser desempenhada pelo direito em suporte ao desenvolvimento dos mercados.

Para além da especificação desses direitos subjetivos e da previsão de meios para assegurá-los, o direito pode desempenhar, por exemplo, funções de coordenação da atividade econômica. ${ }^{304}$ Trata-se de papel desempenhado pelo direito em economias de mercado e que não é redutível à proteção dos direitos de propriedade e à aplicação de sanções para quem tenta violá-los.

O Takeover Panel britânico pode ser mencionado como exemplo de atividade de coordenação promovida pelo direito em suporte à atividade econômica. Fundado em 1968 pela iniciativa privada, é reconhecido como órgão responsável pela resolução de disputas em torno de mudanças de controle societário por intermédio de compra de ações (takeovers). Órgão não-estatal, é composto por juristas, por contadores e por representantes dos próprios regulados (sociedades financeiras, companhias seguradoras, associações de indústrias, dentre outros). Longe de reproduzir o modelo de litigância pressuposto na visão meramente protetora do direito, funciona por meio de consultas de interessados que são respondidas com base em princípios desenvolvidos pelo próprio órgão e que acabam por balizar o comportamento dos agentes econômicos no mercado acionário. ${ }^{305}$

Milhaupt e Pistor, ao analisarem um caso alemão de governança corporativa, também citam como exemplo de atividade de coordenação a previsão legal da representação de trabalhadores no órgão que indica os membros do conselho de administração de uma companhia. ${ }^{306}$ Ora, nesse caso, o legislador não pretende reforçar o direito individual de propriedade dos acionistas, mas sim estimular que acionistas, administradores e trabalhadores

\footnotetext{
${ }^{304}$ Milhaupt e Pistor, Law and Capitalism, 2008, p. 32-36. A respeito, cf. FARIA, J. O direito na economia globalizada. São Paulo: Malheiros, 1999, p. 163.

${ }_{305}$ Mais informações em www.thetakeoverpanel.org.uk. O exemplo é citado por Milhaupt e Pistor. Em Law and Finance, La Porta et al. dizem expressamente que as regras de takeover, de fusões e aquisições, dentre outras, não foram consideradas. O que se critica, contudo, não é o fato de que regras sobre determinada tenham sido deixadas de fora, mas sim que todas as regras consideradas dizem respeito a regras formais. Cf. p. 1120.

${ }^{306}$ Milhaupt e Pistor, Law and Capitalism, 2008, p. 32-36.
} 
coordenem seus interesses na definição de estratégias corporativas e, com isso, compartilhem o processo de tomada de decisão na empresa. ${ }^{307}$

Propositadamente, foram reproduzidos dois exemplos de atividades de coordenação recolhidos de experiências de países desenvolvidos. São dois casos em que a função do direito deixa de estar identificada com o mero enforcement de direitos subjetivos, por meio de um processo de litigância bilateral mediado por um terceiro representante do detentor do monopólio do uso da força. ${ }^{308}$

Caso se considere o direito como produto da interação humana, é duvidoso que a clara alocação de direitos de propriedade seja compatível com a premissa teórica da racionalidade limitada, exposta no capítulo 1 . Se o indivíduo não é capaz de processar mentalmente todas as suas possibilidades de ação nem de antever o que acontecerá em razão de suas escolhas, como cogitar a possibilidade de definição inequívoca dos direitos de propriedade, que pressupõe informação completa? Reconhece-se que os contratantes não são capazes de controlar todas as variáveis que podem influir na execução futura de um contrato, mas se exige da lei que a alocação de direitos seja feita de maneira evidente. ${ }^{309}$

Em suma, na avaliação do papel a ser desempenhado pelo direito em suporte à atividade econômica, a perspectiva da dotação institucional considera apenas a função protetora de direitos de propriedade respaldados por regras repressivas de condutas violadoras.

A perspectiva da dotação institucional também pressupõe uma relação específica entre direito e política. Foca sua atenção na medição da influência do direito na atividade

\footnotetext{
${ }^{307}$ Milhaupt e Pistor, Law and Capitalism, 2008, p. 33.

${ }^{308}$ Milhaupt e Pistor citam, ainda, as funções de sinalização e de aumento de credibilidade desempenhadas pelo direito em suporte à atividade econômica. Cf. Milhaupt e Pistor, Law and Capitalism, 2008, p. 34-36.

${ }^{309}$ Sobre a "incompletude do direito", cf. XU, C.; PISTOR, K. Law Enforcement Under Incomplete Law: Theory and Evidence from Financial Market Regulation. Columbia Law and Economic Working Paper n. 222, nov. 2002. Disponível em: 〈http://ssrn.com/abstract=396141〉. Acesso em 15 dez. 2008. Hart, que se refere à "textura aberta do direito", é uma referência clássica sobre o assunto. Cf. HART, H. O Conceito de Direito, 2. ed., Lisboa: Calouste Gulbenkian, 1994, especialmente p. 137-149.
} 
econômica e desconsidera os processos sociais de desenvolvimento do direito. Com isso, despolitiza a mudança jurídica, enxergando-a como tarefa de engenharia social.

Ao associar crescimento econômico a uma certa conformação e a um certo conteúdo do direito, essa perspectiva acaba por prescrever parâmetros para distinguir regras jurídicas boas de regras jurídicas ruins. A capacidade de proporcionar eficiência às trocas econômicas, minimizando custos de transação, é o critério diferenciador decisivo. ${ }^{310} \mathrm{E}$ o universo de garimpo dessas boas regras são as experiências bem-sucedidas de países desenvolvidos.

Com isso, a identificação de regras jurídicas aptas a gerar um ambiente adequado para o crescimento passa a ser enxergada como uma tarefa técnica; e a reprodução desse ambiente em jurisdições que não o desenvolveram passa a ser vista como mera questão de transferência de tecnologia jurídica, a ser conduzida por especialistas.

Aqui, importa destacar somente uma decorrência dessa assunção: a visão evolucionista do direito. Relacionando o desempenho econômico dos países à presença ou ausência de regras específicas de proteção de direitos subjetivos, a perspectiva da dotação institucional acaba por sugerir que o desenvolvimento econômico é atingível simplesmente pela incorporação de determinadas regras, como se a expansão econômica seguisse uma linha evolutiva e como se a "etapa" do desenvolvimento das boas regras pudesse ser saltada pelos países em transição ou em desenvolvimento. ${ }^{311}$

A natureza do direito é tomada como incontroversa: o bom direito é conhecido, pois já foi testado e aprovado no mundo ocidental desenvolvido. O caráter problemático não é a sua identificação, mas a sua implementação, que é questão de ordem técnica, a ser feita de modo racional com vistas à expansão econômica.

\footnotetext{
${ }^{310}$ Não assumo que o conceito de eficiência seja livre de valor. A respeito, cf. Rittich, Recharacterizing Restructuring, 2002.

${ }^{311}$ Milhaupt e Pistor, Law and Capitalism, 2008, p. 202.
} 
Essa tecnicização despolitiza o debate sobre o conteúdo das reformas jurídicas prómercado, que passam a ser defendidas como caminho único para o crescimento econômico. ${ }^{312}$ Despolitiza, ainda, o processo de incorporação dessas regras nos ordenamentos jurídicos nacionais que não as desenvolveram. Por se saber de antemão quais são as boas regras jurídicas - que já foram testadas e aprovadas em países desenvolvidos -, não será o debate na esfera pública que aperfeiçoará as propostas a serem implementadas.

A literatura da Law and Finance dá pouco peso ao fato de que qualquer mudança legal pode gerar respostas adaptativas dos seus destinatários. ${ }^{313} \mathrm{Em}$ linha com a premissa teórica da racionalidade limitada do indivíduo, o mais coerente seria pressupor a impossibilidade de se criar uma regra que, com certeza, trará somente resultados eficientes, seja qual for o contexto.

Silencia-se também sobre a possibilidade de influência mútua entre regras preexistentes e regras transplantadas, que poderia dar origem a configurações não imaginadas pelos reformadores. ${ }^{314}$ Imagina-se que a reforma é feita unilateralmente, sem contestação dos atores envolvidos no processo legislativo, e que as regras incorporadas passam a produzir os efeitos esperados de modo automático e independente dos agentes responsáveis pela fixação de sentido e aplicação do direito. ${ }^{315}$ Conforme visto, espera-se que o controle na aplicação do direito seja feito pela edição de regras jurídicas inequívocas, livres de qualquer ambiguidade e sem qualquer espaço para julgamentos discricionários.

O fato de a perspectiva da dotação institucional tomar o direito como politicamente neutro articula-se diretamente com os pressupostos que embasam os mecanismos usados para implementar essas reformas em países em desenvolvimento e em economias em transição.

Boa parte dessas reformas é financiada pelo Banco Mundial, que é impedido estatutariamente de interferir em questões políticas de seus países-membros. Em razão disso e do próprio esforço dos seus dirigentes em justificar a atuação do Banco no campo jurídico-

\footnotetext{
${ }^{312}$ Rittich, Recharacterizing Restructuring, 2002, p. 12 e 94.

${ }^{313}$ Milhaupt e Pistor, Law and Capitalism, 2008, p. 202.

${ }^{314}$ Milhaupt e Pistor, Law and Capitalism, 2008, p. 22 e capítulo 10.

${ }^{315}$ Milhaupt e Pistor, Law and Capitalism, 2008, p. 41 e 202.
} 
institucional, não seria absurdo cogitar que a tecnicização da transferência de know-how jurídico busca contornar esse óbice à ação política e legitimar prerrequisitos para a concessão de empréstimos, que vinculam a liberação de fundos à implementação das estratégicas do Banco. ${ }^{316}$ Em regra, os projetos desse tipo financiados pelo Banco Mundial têm o sugestivo nome de "assistência técnica".

A concepção de direito pressuposta pela Law and Finance pode também ser depreendida do tipo específico de regra jurídica valorizada em seus estudos.

Conforme visto no capítulo 1, os estudos da Law and Finance valem-se de pesquisas empíricas que buscam verificar - em cada país estudado - a existência de regras jurídicas tidas como propulsoras do crescimento econômico. No estudo pioneiro da Law and Finance, por exemplo, o nível de desenvolvimento dos mercados financeiro e de capitais foi associado, num primeiro momento, à existência de determinadas regras de proteção aos direitos de credores e de acionistas. Cotejando as regras previstas nos ordenamentos jurídicos dos países estudados, La Porta et al. encontraram, num segundo momento, uma correlação entre o nível de proteção legal dos investidores e a tradição jurídica do país estudado. Países de common law, que também possuem os mercados financeiros mais profundos, obtiveram os níveis mais altos em termos de proteção dos direitos do investidor. As variáveis escolhidas para apontar o nível de proteção do investidor em cada país diziam respeito, todas elas, a regras jurídicas formais. São ignoradas regras e práticas jurídicas informais, como se elas não fossem constitutivas do direito. Nenhum atenção é dada, por exemplo, a formas de autorregulação do mercado. ${ }^{317}$

Seria possível arguir que a opção por verificar a incidência de regras formais fosse uma estratégia de pesquisa, dada a dificuldade de se investigar regras e práticas informais, especialmente em estudos comparativos envolvendo o número de países que essas pesquisas costumam abarcar. Nos trabalhos resenhados no capítulo 1 - considerados como os de maior difusão - não foram encontradas, contudo, justificativas dessa espécie.

\footnotetext{
${ }^{316}$ Santos, The World Bank's Uses of the "Rule of Law” Promise in Economic Development, 2006, p. 271.

${ }^{317}$ É o caso do Takeover Panel britânico, citado acima.
} 
Assim, na medição das condições jurídicas para o crescimento econômico o foco da Law and Finance está voltado exclusivamente para o direito formal. Ignora-se a possibilidade de a sociedade moldar o direito mediante práticas não-formais. Numa perspectiva voluntarista, a atenção está voltada para a maneira como o direito formal molda a sociedade. ${ }^{318}$

É dentro dessa perspectiva que o direito é alçado ao centro do debate sobre crescimento. Porém, ele é tomado como mero sinônimo de regras formais ditadas pelo Estado. $\mathrm{Na}$ relação entre Estado e direito, as regras jurídicas servem, ao mesmo tempo, como limitadoras do próprio poder do Estado e como reforço do poder estatal na proteção das regras tidas como fundamentais para o crescimento econômico.

Essa postura da Law and Finance recepciona apenas parcialmente a teoria da mudança institucional de North, que define instituições como conjunto de regras formais e informais e atribui a essas últimas um papel relevante no crescimento econômico. ${ }^{319}$

\footnotetext{
${ }^{318}$ No mesmo sentido, mas referindo-se a outro contexto (movimento Direito e Desenvolvimento das décadas de 1960 e 1970), LOPES, J. R. L. Direito e transformação social: ensaio interdisciplinar das mudanças no Direito. Belo Horizonte: Nova Alvorada, 1997, p. 162-168. Para uma crítica do movimento mencionado, cf. TRUBEK, D.; GAllanter, M. Acadêmicos auto-alienados: reflexões sobre a crise norte-americana da disciplina "Direito e Desenvolvimento", Revista Direito GV, v. 3, n. 2, 2007, p. 261-304. Para uma comparação entre o movimento Direito e Desenvolvimento e a literatura da Law and Finance, cf. SCHMIDBAUER, R. Law and Development: Dawn of a New Era? University of Manchester - School of Law, Working Paper Series, 2006. Disponível em: http://ssrn.com/abstract=899217.

${ }^{319}$ Segundo Trebicolck e Leng, Japão, da China e da Coréia do Sul, durante a segunda metade do século XX, apresentaram altas taxas de crescimento econômico, mesmo sem contar com regras que definiam claramente e protegiam os direitos de propriedade. Cf. LENG, J.; TREBILCOCK, M. The Role of Formal Contract Law and Enforcement in Economic Development, Virginia Law Review, 92, p. 1517-1580, 2006. Na mesma linha, Milhaupt e Pistor, Law and Capitalism, 2008, p. 39. Sobre a definição de instituição, cf. North, Institutions, Institutional Change, and Economic Performance, 1996, p. 239; NORTH, D. Institutions, The Journal of Economic Perspectives, v. 5, n. 1, inverno 1991, pp. 97-112. Disponível em: <http://www.jstor.org/stable/pdfplus/1942704.pdf >. Acesso em: 15 dez. 2008.
} 


\section{CONCluSÃo}

O propósito desta pesquisa foi investigar as expectativas em relação ao direito presentes em medidas sugeridas pelo Banco Central do Brasil (BCB), entre os anos de 1999 e 2006, para a reforma do mercado de crédito brasileiro. Com esse intuito, este trabalho analisou os argumentos apresentados para justificar a implementação de um conjunto específico de sugestões de mudança do direito atinente aos sistemas de insolvência e de cobrança de dívidas, sistemas esses tidos como decisivos para o desenvolvimento financeiro de um país.

A base de análise foram os relatórios anuais do Projeto Juros e Spread Bancário, elaborados pelo Departamento de Estudos e Pesquisas do BCB. Subsidiariamente, também serviu de corpus o texto Reformas microeconômicas e crescimento de longo prazo, preparado pela Secretaria de Política Econômica do Ministério da Fazenda (SPE/MF). Esse texto é tomado como referência para colher dados de 2003 e de 2004, período em que surge nos relatórios do PJSB a ressalva de que as opiniões expressas ali não representam a posição oficial do Governo a respeito dos temas tratados.

A hipótese de pesquisa era a de que as justificativas apresentadas por esses documentos para a implementação das medidas denotavam uma visão do direito específica, designada neste trabalho como perspectiva da dotação institucional. Segundo essa perspectiva, um determinado arranjo do direito seria precondição para o crescimento econômico: sem a clara definição de direitos de propriedade (direitos dos credores incluídos) e sem eficientes mecanismos para o cumprimento de contratos, não haveria desenvolvimento financeiro.

Com base em referências teóricas da Nova Economia Institucional - mais especificamente Douglass North e a corrente da literatura econômica conhecida como Law and Finance -, foi elaborado um quadro de categorias que permitiu o cotejo entre a perspectiva da dotação institucional e as justificativas encontradas no corpus da pesquisa. Nesse quadro, foram consideradas duas dimensões de análise: uma que diz respeito à 
previsibilidade de comportamentos, outra atinente à celeridade procedimental. Cada dimensão foi especificada em focos e em objetivos, que conferiram instrumentalidade às categorias.

Foram analisadas seis medidas propostas pelo PJSB: $(a)$ criação da cédula de crédito bancário; (b) aumento do alcance da alienação e da cessão fiduciárias; $(c)$ reconhecimento do acordo para compensação de pagamentos; $(d)$ previsão legal do crédito consignado em folha de pagamento; $(e)$ reforma da Lei de Falências; e $(f)$ racionalização dos processos judiciais.

No confronto das categorias com os argumentos para a implementação dessas medidas, foram identificados graus variados de correspondências de sentido. Uma das medidas (reconhecimento do acordo para a compensação de pagamentos) refletiu apenas genericamente a dimensão da previsibilidade. Em relação às outras cinco medidas, pode-se dizer que o discurso de justificativa apresentado não só incorporou as dimensões da previsibilidade e da celeridade de modo amplo, como também sugeriu a adoção de regras específicas valorizadas pelos estudos econométricos nos quais esta tese se baseou para construir os parâmetros de análise.

A correspondência identificada entre categorias e medidas é consistente com duas evidências encontradas no curso da execução da pesquisa: (a) para embasar a proposição de algumas medidas, os documentos oficiais citam referências teóricas da perspectiva da dotação institucional; e $(b)$ as medidas analisadas encontram-se, todas elas, mencionadas em relatórios do Banco Mundial como atividades preparatórias para a obtenção de financiamento ou como resultado de projetos financiados. A relevância desse fato decorre da conjugação de três fatores: (i) os estudos da Law and Finance oferecem a base metodológica para um dos mais importantes projetos de avaliação de ambiente de negócios do Banco Mundial (Doing Business), também usado por várias áreas do BM para medir o impacto de reformas financiadas em seus países membros; (ii) o BM assumidamente vincula a concessão de financiamento à implementação de suas estratégias; (iii) os agentes de implementação das ações financiadas pelo Banco Mundial foram o BCB e a SPE/MF, instituições autoras dos documentos que veiculam as medidas de reforma do crédito aqui analisadas. 
A coerência no tempo entre as medidas do PJSB poderia, inclusive, ensejar que se fale não em reformas do mercado de crédito, mas em reforma, no singular, do mercado de crédito, a despeito de terem sido implementadas ao longo de oito anos e sugeridas sob a égide de dois Governos distintos.

Depois de associar as medidas de reforma do mercado de crédito brasileiro à dotação institucional, esta tese discorreu sobre a concepção de direito presente nessa visão. Para tanto, o presente estudo passou por considerações metodológicas e pelos pressupostos teóricos da Law and Finance. Na abordagem metodológica discutiu algumas opções de pesquisa, além de assuntos de coerência interna e também de harmonia com as premissas da Nova Economia Institucional conforme assumida por North.

Em relação aos pressupostos da Law and Finance, foram abordadas as interfaces direito e economia e direito e política, além de terem sido examinadas as expectativas da dotação institucional sobre a função do direito.

$\mathrm{Na}$ interface direito e economia, foi identificada uma relação de causalidade unidirecional: a influência de um campo no outro se dá num sentido único, do direito para a economia. Dessa forma, o direito é assumido como variável exógena e não é reconhecida a possibilidade de influência recíproca entre direito e mercado. Nas atividades em suporte ao mercado, a dotação institucional aponta como relevante apenas o papel protetor do direito. A despeito de ser notoriamente importante que o direito desempenhe essa função, foram aventadas outras formas de este apoiar a atividade de mercado.

$\mathrm{Na}$ interface entre direito e política, foi abordada a tecnicização do processo de mudança legal, muitas vezes tomado pelos teóricos da Law and Finance como uma questão politicamente neutra e de mera incorporação de regras internacionalmente reconhecidas como as melhores para se promover o desenvolvimento financeiro. $\mathrm{O}$ direito parece ser tomado como incontroverso e não é devidamente reconhecida a importância da interação entre os agentes e as instituições para desenvolvê-lo nem a possibilidade de respostas adaptativas do meio social durante o processo de implementação dessas regras-padrão. 
Pelo que se pôde depreender das variáveis relevantes selecionadas pela Law and Finance para medir o nível de proteção aos credores nos vários países estudados, o direito parece ser compreendido, pelos teóricos dessa linha da literatura econômica, como um conjunto de regras formais. Não são consideradas como constitutivas do direito, por exemplo, formas de autorregulação do mercado nem outras regras ou práticas informais.

Em suma, esta tese buscou demonstrar a noção de direito implícita nos documentos que sugeriram mudanças no mercado de crédito brasileiro. $O$ caráter quase linear de correspondência entre, de um lado, os pressupostos econômicos abraçados pela perspectiva teórica da dotação institucional e pelo Banco Mundial e, de outro, a sua tradução jurídica conforme preconizada pelos relatórios do BCB aponta claramente para uma visão específica do direito. Este é tomado como mero instrumento de proteção dos interesses dos credores, como se desempenhasse, em suporte à atividade econômica, apenas essa função. No caso deste estudo, em particular, a argumentação dos documentos oficiais - e o tipo de reforma jurídica que preconizam para a proteção dos interesses dos credores - sugere uma leitura do direito como suporte necessário à atividade econômica, restringindo-o, em termos práticos, a essa função, e valorando-o segundo sua maior ou menor eficiência em promover resultados no âmbito econômico.

Essa visão parece despir o direito de seu caráter de mediador de conflitos mais amplos, supondo-o como politicamente neutro. Como se baseia em regras supostamente mensuráveis, testadas e aprovadas, tal perspectiva desqualifica a alegação de razões diversas como se elas fossem antagônicas ao crescimento econômico e ao desenvolvimento social. Uma vez que vêm apoiados em estudos econométricos fartos de dados e de grandezas quantitativamente comparáveis, os textos elaborados com base nessa visão estruturam um discurso que acaba por apresentar as soluções que prescrevem como sendo caminhos inquestionáveis, já que identificados com base em uma lógica mensurável. Ao estabelecer - supostamente - uma relação causal entre comportamento e resultado, tal perspectiva sugere a desqualificação objetiva de argumentos contrários e ganha força porque discursivamente associa determinadas condutas econômicas à melhoria nas condições sociais. A implementação das regras 
valorizadas por essa literatura ignora, entretanto, aspectos contextuais não-econômicos, naturaliza visões pontuais de crescimento, desqualifica o debate político sobre soluções alternativas e minimiza o papel do direito como instrumento social de mediação de conflitos e diferenças. 


\section{Bibliografia Citada}

ABA - American Bar Association. Multinational Commercial Insolvency. Chicago: ABA, 1989.

. Multinational Commercial Insolvency. Chicago: ABA, 1993.

ARAÚJO, A.; LunDBERG, E. A Nova Lei de Falências: uma avaliação. In: BCB, Economia bancária e crédito. 2003. p. 44-57.

ARIDA, P.; BACHA, E. L.; LARA-RESEndE, A. Credit, Interest, and Jurisdictional Uncertainty: Conjectures on the Case of Brazil. In: GIAVAZZI, F.; GoldFAJN, I. (eds.) Inflation Targeting and Debt: the Case of Brazil. Cambrigde: MIT, 2004. p. 265-293.

ARMOUR, J.; DeAkIn, S.; SARKAR, P.; SIEMS, M; Singh, A. Shareholder Protection and Stock Market Development: an empirical test of the legal origins hypothesis, 2007, CBR Working Paper Series. Disponível em: 〈http://ssrn.com/abstract=1094355>. Acesso em 15 dez. 2008.

Armour, J.; Black, B.; ChefFins, B.; Nolan, R. Private Enforcement of Corporate Law: An Empirical Comparison of the US and UK, European Corporate Governance Institute Working Paper, 2007. Disponível em:

$<$ http://www.ecgi.org/competitions/rof/files/UK_US_corp_law_enforcement_draft_ECGI.pdf $>$. Acesso em 15 dez. 2008.

ARMOUR, J. Codification and UK Company Law. Disponível em:

<http://www1.fee.uva.nl/fm/conference/legal/2008\%20Company\%20Law\%20Codification\%2 0Dalloz.pdf $>$. Acesso em 15 dez. 2008.

Banco Mundial. Project Appraisal Document. Relatório n. 16867-BR, 23/10/1997, anexo 2, p. 2. Disponível em:

<http://web.worldbank.org/external/projects/main?pagePK=64283627\&piPK=73230\&theSite $\mathrm{PK}=40941 \& \mathrm{menuPK}=228424 \&$ Projectid=P048357>. Acesso em 15 dez. 2008.

Resolution of Financial Distress: An International Perspective on the Design of Bankruptcy Laws. Washington: Banco Mundial, 2001. 
. Principles and guidelines for effective insolvency and creditor rights systems, 2001, p. 37. Disponível em: <http://www.docstoc.com/docs/1002989/Principles-and-Guidelines-forEffective-Insolvency-and-Creditor-Rights-Systems $>$. Acesso em 15 dez. 2008.

Implementation Completion and Results Report. Relatório n. 25116, 17/12/2002.

Disponível em:

<http://web.worldbank.org/external/projects/main?pagePK=64283627\&piPK=73230\&theSite $\underline{\mathrm{PK}=40941 \& \mathrm{menuPK}=228424 \& \text { Projectid=P070640) }}$. Acesso em 15 dez. 2008.

. Project Appraisal Document. Relatório n. 27987, 19/05/2004, p. 6. Disponível em: $<$ http://web.worldbank.org/external/projects/main?pagePK=64283627\&piPK=73230\&theSite

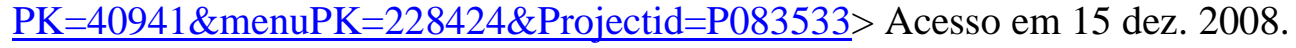

Implementation Completion and Results Report, Relatório, n. 32604, 28/06/2005. Disponível em:

$<$ http://web.worldbank.org/external/projects/main?pagePK=64283627\&piPK=73230\&theSite

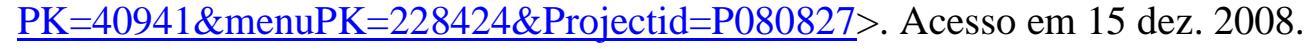

Brazil: Investment Climate Assessment, v. 2, 2005. Disponível em:

$<$ http://www.enterprisesurveys.org/documents/enterprisesurveys/ICA/Brazil_Volume\%20I.pd f>. Acesso em 15 dez. 2008.

Implementation Completion and Results Report. Relatório n. ICR0000924, 06/11/2008, p. 9. Disponível em:

<http://web.worldbank.org/external/projects/main?pagePK=64283627\&piPK=73230\&theSite

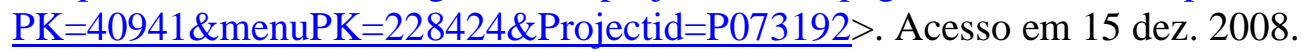

BCB - Banco Central do Brasil. Juros e spread bancário no Brasil. Brasília, 1999 a 2001. Disponível em: 〈http://www.bcb.gov.br/?SPREAD>. Acesso em: 15 dez. 2008.

. Economia bancária e crédito. Brasília, 2002 a 2004. Disponível em: <http://www.bcb.gov.br/?SPREAD>. Acesso em: 15 dez. 2008.

. Realtório de economia bancária e crédito. Brasília, 2005 e 2006. Disponível em: <http://www.bcb.gov.br/?SPREAD>. Acesso em: 15 dez. 2008. 
BeCK, T.; DEMIRGÜÇ-Kunt, A.; LEVINE, R. Law, Endowments, and Finance, Journal of Financial Economics, v. 70, n. 2, 2003, p. 137-181.

BECK, T.; LEVINE, R. Legal Institutions and Financial Development. In: MÉNARD, C.; SHIRLEY, M. (eds.) Handbook of New Institutional Economics. Dordrecht: Springer, 2005. p. 251-278.

BID - Banco Interamericano de Desenvolvimento. Libertar o crédito: como aprofundar e estabilizar o financiamento bancário. Rio de Janeiro: Elsevier, 2005.

BobBio, N. O positivismo jurídico: lições de Filosofia do Direito. São Paulo: Ícone, 1995. Teoria do ordenamento jurídico. 10. ed. Brasília: UnB, 1997.

CARVAlho, C.; VidotTo, C. Abertura do setor bancário ao capital estrangeiro nos anos 1990: os objetivos e o discurso do governo e dos banqueiros. Nova Economia, v. 17, 2007.

Chu, V.; Lundberg, E.; TAKedA, T. Por que o volume de empréstimo consignado no setor privado é tão baixo? Qual a solução? In: $\mathrm{BCB}$, Relatório de economia bancária e crédito, 2007. p. 73-83.

Colombo, G. Lei $n^{o}$ 10.931/04: alterações na legislação sobre alienação fiduciária. São Paulo: Pinheiro Neto, 2004, p. 2. Disponível em: http://www.ibrademp.org.br. Acesso em: 15 dez. 2008.

Costa, A. C.; Mello, J. M. Judicial risk and credit market performance: micro evidence from Brazilian payroll loans. NBER. Working paper 12.252, mai. 2006.

DAVID, R. Os grandes sistemas do direito contemporâneo. 3. ed. São Paulo: Martins Fontes, 1998.

DAvis, K.; KRUSE, M. Taking the Measure of Law: The Case of the Doing Business Project. Law \& Social Inquiry, v. 32, n. 4, p. 1095-1119, 2007.

DemirgüÇ-Kunt, A.; Maksimovic, V. Law, Finance, and Firm Growth. Journal of Finance, 53, p. 2107-2137, 1998. 
Dinamarco, C. Instituições de Direito Processual Civil. São Paulo: Malheiros, 2005. v. 1.

DJANKov, S. et. al. Courts. Quarterly Journal of Economics, n. 118, p. 453-517, 2003.

DoING Business. Projeto de avaliação de ambiente de negócios do Banco Mundial. Disponível em: www.doingbusiness.org. Acesso em 15 dez. 2008.

EwING, S. Formal justice and the spirit of capitalism: Max Weber's sociology of law. Law and Society Review, v. 21, n. 3, p. 487-512, 1987.

FachadA, P.; Figueiredo, L. F.; LundBerg, E. Sistema judicial e mercado de crédito no Brasil. Nota Técnica n. 35. Brasília: Banco Central do Brasil, 2003. Disponível em: http://www.bcb.gov.br/pec/NotasTecnicas/Port/2003nt35sistemajudicialmercadocredbrasilp.p df.

FARIA, J. O direito na economia globalizada. São Paulo: Malheiros, 1999, p. 163.

FUNKEN, K. The best of both worlds: the trend towards convergence of the civil law and the common law system. Working paper, University of Munich School of Law, 2003.

Furubotn, E.; RichteR, R. Institutions \& Economic Theory: The Contribution of the New Institutional Economics. 2. ed. Ann Arbor: University of Michigan, 2005.

GETTING the Deal Through Series. Insolvency \& Restructuring. Londres: Law Business Research, 2003.

GOODHART, C. et al. Financial regulation: why, how and where now? Londres: Routledge, 1998.

HaRT, H. O Conceito de Direito, 2. ed., Lisboa: Calouste Gulbenkian, 1994.

HERnÁNDEZ SAMPIERI, R.; FERnÁnDEZ COLlADO, C.; BAPTISTA LuCIO, P. Metodologia de pesquisa. 3. ed. São Paulo: McGraw-Hill, 2006. 
InSTITUTIONAL Shareholder Services. Proxy Voting Guidelines. Washington: ISS Global Proxy Services, 1994.

INVESTOR Responsibility Research Center, Proxy Voting Guide. Washington: Investor Responsability Research Center, 1994/1995.

LA PORTA, R. et. al. Legal Determinants of External Finance. Journal of Finance, n. 52, p. 1131- 1150, 1997.

. Law and Finance. Journal of Political Economy, n. 106, p. 1113-1155, 1998.

. Investor Protection and Corporate Governance, Journal of Financial Economics, n. 58, p. 3-27, 2000. 1170,2002

Investor Protection and Corporate Valuation, Journal of Finance, v. 57, n. 3, p. 1147 -

LA PoRTA, R.; LÓPEZ-DE-SilAnES, F.; SHLEIFER, A. Corporate Ownership Around the World, Journal of Finance, v. 54, n. 2, p. 71-517, 1999.

The Economic Consequences of Legal Origins. Journal of Economic Literature, v. 46, n. 2, p. 285-332, jun. 2008.

LENG, J.; TREBILCOCK, M. The Role of Formal Contract Law and Enforcement in Economic Development. Virginia Law Review, 92, p. 1517-1580, 2006.

Levine, R.; ZeRvos, S. Stock Markets, Banks, and Economic Growth. American Economic Review, v. 88, n. 3, p. 537-558, 1998.

LOPES, J. R. L. Direito e transformação social: ensaio interdisciplinar das mudanças no Direito. Belo Horizonte: Nova Alvorada, 1997.

Milhaupt, C.; Pistor, K. Law and Capitalism: What Corporate Crises Reveal About Legal Systems and Economic Development Around the World. Chicago: University of Chicago, 2008. 
Monteiro, W. B. Curso de Direito Civil. 37. ed. São Paulo: Saraiva, 2003.

Moody's Global Banking. Credit Opinion, 16 jan. 2007, p. 2. Disponível em: $<$ http://ri.bancopine.com.br/bancopine/web/arquivos/BANCOPINE_MOODYS_20080128_P ORT.pdf.>. Acesso em 15 dez. 2008.

NAKANE, M.; CostA, A. C. Spread bancário: os problemas da comparação internacional. In: BCB - Banco Central do Brasil. Relatório de economia bancária e crédito. Brasília, 2005, p. $59-68$.

. Institutions, Institutional Change, and Economic Performance. New York:

Cambridge University, 1990.

Institutions, The Journal of Economic Perspectives, v. 5, n. 1, inverno 1991, pp. 97 112. Disponível em: 〈http://www.jstor.org/stable/pdfplus/1942704.pdf >. Acesso em: 15 dez. 2008.

Institutions, Institutional Change and Economic Performance. New York: Cambridge University, 1996.

Economic performance through time. Prize Lecture - Lecture to the memory of Alfred Nobel, 9 dez. 2003, p. 1. Disponível em:

<http://nobelprize.org/nobel_prizes/economics/laureates/1993/north-lecture.html >. Acesso em 30 out. 2008.

. New Institutional Economics and Development. Department of Economics, Washington University, St. Louis, Missouri, p. 1. Disponível em:

<http://129.3.20.41/eps/eh/papers/9309/9309002.pdf. . . Acesso em 15 dez. 2008.

PAUlA, L. F.; MARQUES, M. B. Tendências recentes da consolidação bancária no Brasil. Revista Análise Econômica, v. 24, n. 45, p. 235-263, 2006.

Perelman, C. Lógica jurídica: nova retórica. São Paulo: Martins Fontes, 1998.

PINHEIRO, A. C. O Judiciário e a Economia no Brasil. São Paulo: IDESP, 2000. Mimeo. 
. Economia e justiça: conceitos e evidência empírica. 2001. Disponível em:

www.ifb.com.br/download.php?tindex=estudos\&id=14. Acesso em 15 dez. 2008.

. O componente judicial dos spreads bancários. In: BCB. Economia bancária e crédito. 2003. p. 34-43.

Pinheiro, A. C.; CABral, C. Mercado de crédito brasileiro: o papel do Judiciário e de outras instituições. Rio de Janeiro: BNDES, 1998.

Pinheiro, A. C.; Moura, A. Segmentação e uso de informação nos mercados de crédito brasileiros. Texto para discussão n. 88, Rio de Janeiro: BNDES, fev. 2001.

PISTOR, K. Legal Ground Rules in Coordinated and Liberal Market Economies. ECGI Law Working Paper n. 30, 2005.

PRADO, F. R. A.; LeSSA, T. A. D. T.; SPINA, A. O reconhecimento da validade de acordos para compensação de débitos e créditos em operações financeiras: a nova regulamentação do Conselho Monetário Nacional. Disponível em: 〈www.migalhas.com.br $\rangle$. Acesso em 5 out. 2008.

PuGA, F. Sistema financeiro brasileiro: reestruturação recente, comparações internacionais e vulnerabilidade à crise cambial. In: GIAMBIAGI, F.; MoREIRA, M. A economia brasileira nos anos 90. Rio de Janeiro: BNDES, 1999, p. 415-16.

Rajan, R.; Zingales, L. Financial Dependence and Growth. American Economic Review, v. 88, n. 3, p. 559-586, 1998.

. The Great Reversals: The Politics of Financial Development in the Twentieth Century, Journal of Financial Economics, n. 69, p. 5-50, 2003.

Reynolds, T.; Flores, A. Foreign Law: Current Sources of Codes and Basic Legislation in Jurisdictions of the World. Littleton: Rothman and Co., 1989.

RITTICH, K. Recharacterizing Restructuring: Law, Distribution and Gender in Market Reform. Boston: Kluwer Law International, 2002. 
RizZARDo, A. Contratos de crédito bancário, 6. ed. São Paulo: Revista dos Tribunais, 2003.

RODRIGUES, E. et al. O efeito da consignação em folha nas taxas de juros dos empréstimos pessoais. In: BCB, Relatório de economia bancária e crédito. Brasília, 2005. p. 89-101. Disponível em: <http://www.bcb.gov.br/?SPREAD>. Acesso em: 15 dez. 2008.

SADDI, J. Crédito e Judiciário no Brasil: uma análise de Direito \& Economia. São Paulo: Quartier Latin, 2007. Parte 2.

Santos, A. The World Bank's Uses of the "Rule of Law" Promise in Economic Development. In: TrubeK, D.; SAntos, A. (eds.) The New Law and Economic Development: A Critical Appraisal. Nova York: Cambridge University, 2006. p. 253-300.

ShIHATA. I. The Role of Law in Business Development, Fordham International Law Review, n. 20, p. 1577-1588, 1996-1997.

Schmidbauer, R. Law and Development: Dawn of a New Era? University of Manchester School of Law, Working Paper Series, 2006. Disponível em: $\langle$ http://ssrn.com/abstract=899217>. Acesso em 15 dez. 2008.

SHLEIFER, A.; ViSHNY, R. W. A Survey of Corporate Governance. Journal of Finance, v. 52, n. 2., p. 737-783, 1997.

SIEMS, M. Reconciling Law \& Finance and comparative law. McGill Law Journal, n. 52, p. 55-81, 2007.

SOARES, R. Evolução do crédito de 1994 a 1999: uma explicação. Texto para discussão n. 808. Brasília: IPEA, jul. 2001.

Spamann, H. 'Law and Finance' Revisited. Harvard Law School John M. Olin Center for Law, Economics, and Business Discussion Paper n. 12. fev. 2008. Disponível em: <http://ssrn.com/abstract=1095526>. Acesso em 15 dez. 2008.

SPE/MF - Secretaria de Política Econômica do Ministério da Fazenda. Reformas microeconômicas e crescimento de longo prazo. Brasília, 2004. Disponível em: 
$<$ http://www.fazenda.gov.br/spe/publicacoes/reformasinstitucionais/estudos/Texto VersaoFin al5.pdf >. Acesso em: 15 dez. 2008.

SRJ/MJ - Secretaria da Reforma do Judiciário do Ministério da Justiça. Diagnóstico do Poder Judiciário. Brasília: Ministério da Justiça, 2004.

SRJ/MJ - Secretaria da Reforma do Judiciário do Ministério da Justiça. Judiciário e Economia, 2005, p. 14-15. Disponível em:

<http://www.adpema.org/pdf/JudiciarioeEconomia.pdf>. Acesso em 15 dez. 2008.

StiglitZ, J.; WeISS, A. Credit Rationing in Markets with Imperfect Information. American Economic Review, v. 71, n. 3, p. 393-410, 1981.

SWEDBERG, R. Max Weber e a idéia de sociologia econômica. Rio de Janeiro/São Paulo: UFRJ; Beca, 2005.

Teubner, G. Legal Irritants: How Unifying Law Ends Up in New Divergences. In: Hall, P. and Soskice, D. (eds.) Varieties of Capitalism. Oxford: Oxford University, 2001. p. 417-442.

THEODORO JUNIOR, H. A cédula de crédito bancário como título executivo extrajudicial no direito brasileiro. Academia Brasileira de Direito Processual, p. 10. Disponível em: www.abdpc.org.br/artigos/artigo48.htm. Acesso em 15 dez. 2008.

Thomas, C. Re-Reading Weber in Law and Development: A Critical Intellectual History of "Good Governance" Reform. Cornell Law School Research Paper n. 08-034, 2008. Disponível em: <http://ssrn.com/abstract=1313718 >. Acesso em: 15 dez. 2008.

TRUBeK, D. Max Weber sobre direito e ascensão do capitalismo. São Paulo, Revista Direito $G V$, v. 3, n. 1, p. 151-185, 2007.

TRubeK, D.; Gallanter, M. Acadêmicos auto-alienados: reflexões sobre a crise norteamericana da disciplina “Direito e Desenvolvimento". São Paulo, Revista Direito GV, v. 3, n. 2, p. 261-304, 2007.

VISHnY, P. Guide to International Commerce Law. New York: McGraw-Hill, 1994. 
Weber, M. Historia Económica General. México: Fondo de Cultura Económica, 2001.

WeBer, M. Economía y sociedad: esbozo de sociología comprensiva. México: Fondo de Cultura Económica, 2002.

WHITE, M. The costs of corporate bankruptcy: the U.S.-European comparison. Ann Arbor: University of Michigan, 1993.

WIKIPÉDIA. Verbete "Paridade de poder de compra". Disponível em:

<http://pt.wikipedia.org/wiki/Paridade_do_poder_de_compra>. Acesso em 15 dez. 2008.

Xu, C.; Pistor, K. Law Enforcement Under Incomplete Law: Theory and Evidence from Financial Market Regulation. Columbia Law and Economic Working Paper n. 222, nov. 2002. Disponível em: 〈http://ssrn.com/abstract=396141 >. Acesso em 15 dez. 2008. 


\section{ANEXo ÚNICo}

\section{Título do documento}

Projeto Juros e Spread Bancário

\section{Data de publicação}

1999

\section{Medidas propostas}

Ampliação da base de cobertura da Central de Risco

Aperfeiçoamento do Cosif

Aperfeiçoamento do sistema de pagamentos

Aumento de informações da Central de Risco

Aumento de informações dos cadastros de inadimplentes

Contrato eletrônico de crédito

Esclarecimento sobre anatocismo (juros sobre juros) no SFN

Flexibilização dos direcionamentos de crédito

Maior concorrência no cheque especial

Proteção às centrais de riscos (código de defesa do consumidor e sigilo bancário)

Redução de exigências burocráticas

Redução do IOF

Redução dos compulsórios

\section{Objetivos/Justificativas}

Reduzir o limite de valor informado

Aumentar a transparência dos balanços

Consolidar legalmente as modificações que o BC vem realizando no sistema

Melhorar a qualidade das informações, inclusive pela inclusão de informações positivas

Trabalhar pelo estabelecimento de uma lei que regule a proteção das partes contratantes em operações transitadas através da internet e de outros meios eletrônicos

Esclarecer que esse dispositivo da lei da usura não se aplica ao SFN

Propor medidas específicas que diminuam, em geral, os direcionamentos das operações de crédito rural

Promover maior transparência quanto aos juros,encargos e outras condições praticadas nessas operações

Revisar um sem número de exigências que podem ser consideradas excessivas em relação a operações de pequeno valor

Reduzir o impacto do IOF nas operações de crédito, principalmente para os empréstimos para pessoas físicas

Avançar no processo de redução dos compulsórios sobre os depósitos (sempre que compatível com o regime de metas para a inflação) de forma a induzir uma maior alavancagem das operações de crédito e por conseguinte a diluição dos custos administrativos e de capital 


\begin{tabular}{|l|l|}
\hline Securitização e negociação de recebíveis & $\begin{array}{l}\text { Tomar medidas destinadas a estimular a } \\
\text { disseminação e crescimento desse mercado }\end{array}$ \\
\hline Transparência das operações bancárias & $\begin{array}{l}\text { Levantar informações mais detalhadas sobre juros } \\
\text { e encargos das principais operações de crédito e } \\
\text { divulgá-las, via internet, à população }\end{array}$ \\
\hline $\begin{array}{l}\text { Tratamento da dedução do IR/CSLL sobre } \\
\text { provisionamento de créditos }\end{array}$ & $\begin{array}{l}\text { Estudar a viabilidade de maior uniformização } \\
\text { desses procedimentos }\end{array}$ \\
\hline $\begin{array}{l}\text { Separação da discussão judicial de juros e } \\
\text { principal }\end{array}$ & \\
\hline Aplicabilidade do juízo arbitral & \\
\hline Observações & \\
\hline As informações desse quadro foram transcritas do relatório do PJSB de 1999. \\
\hline
\end{tabular}




\section{Título do documento}

Projeto Juros e Spread Bancário

\section{Data de publicação}

2000

\begin{tabular}{|c|c|}
\hline Medidas propostas & Objetivos/Justificativas \\
\hline $\begin{array}{l}\text { Ampliação da base de cobertura da Central de } \\
\text { Risco }\end{array}$ & Reduzir o limite de valor informado \\
\hline Aperfeiçoamento do Cosif & Aumentar a transparência dos balanços \\
\hline Aperfeiçoamento do sistema de pagamentos & $\begin{array}{l}\text { Consolidar legalmente as modificações que o BC } \\
\text { vem realizando no sistema }\end{array}$ \\
\hline Aumento de informações da Central de Risco & $\begin{array}{l}\text { Melhorar a qualidade das informações, inclusive } \\
\text { pela inclusão de informações positivas }\end{array}$ \\
\hline Contrato eletrônico de crédito & $\begin{array}{l}\text { Trabalhar pelo estabelecimento de uma lei que } \\
\text { regule a proteção das partes contratantes em } \\
\text { operações transitadas através da internet e de } \\
\text { outros meios eletrônicos }\end{array}$ \\
\hline Derivativos de crédito & $\begin{array}{l}\text { Possibilitar o uso desses instrumentos de redução } \\
\text { e transferência dos riscos de crédito }\end{array}$ \\
\hline $\begin{array}{l}\text { Esclarecimento sobre anatocismo (juros sobre } \\
\text { juros) no SFN }\end{array}$ & $\begin{array}{l}\text { Esclarecer que esse dispositivo da lei da usura } \\
\text { não se aplica ao SFN }\end{array}$ \\
\hline Flexibilização dos direcionamentos de crédito & $\begin{array}{l}\text { Propor medidas específicas que diminuam, em } \\
\text { geral, os direcionamentos das operações de } \\
\text { crédito rural }\end{array}$ \\
\hline Fricções na intermediação financeira & $\begin{array}{l}\text { Reduzir os problemas que oneram a } \\
\text { intermediação }\end{array}$ \\
\hline Maior concorrência no cheque especial & $\begin{array}{l}\text { Promover maior transparência quanto aos } \\
\text { juros,encargos e outras condições praticadas } \\
\text { nessas operações }\end{array}$ \\
\hline $\begin{array}{l}\text { Modificações nas regras de classificação das } \\
\text { operações de crédito e de constituição de } \\
\text { provisões }\end{array}$ & $\begin{array}{l}\text { Aumentar a segurança das operações de crédito, } \\
\text { disseminando uma melhor cultura de crédito no } \\
\text { País }\end{array}$ \\
\hline $\begin{array}{l}\text { Modificações nas regras de classificação das } \\
\text { operações de crédito e de constituição de } \\
\text { provisões }\end{array}$ & $\begin{array}{l}\text { Aumentar a segurança das operações de crédito, } \\
\text { disseminando uma melhor cultura de crédito no } \\
\text { País }\end{array}$ \\
\hline Portabilidade de informações cadastrais & $\begin{array}{l}\text { Aumentar a concorrência bancária, autorizando } \\
\text { os clientes transfiram seus cadastros a outra } \\
\text { instituição financeira }\end{array}$ \\
\hline Promoção institucional da Central de Risco & $\begin{array}{l}\text { Esclarecer o papel dessa Central enquanto } \\
\text { instrumento de disseminação de informações } \\
\text { positivas }\end{array}$ \\
\hline Redução de exigências burocráticas & $\begin{array}{l}\text { Revisar um sem número de exigências que podem } \\
\text { ser consideradas excessivas em relação a } \\
\text { operações de pequeno valor }\end{array}$ \\
\hline
\end{tabular}




\begin{tabular}{|l|l|}
\hline Redução do IOF & $\begin{array}{l}\text { Reduzir o impacto do IOF nas operações de } \\
\text { crédito, principalmente para os empréstimos para } \\
\text { pessoas físicas }\end{array}$ \\
\hline Securitização e negociação de recebíveis & $\begin{array}{l}\text { Tomar medidas destinadas a estimular a } \\
\text { disseminação e crescimento desse mercado }\end{array}$ \\
\hline Securitização e negociação de recebíveis & $\begin{array}{l}\text { Tomar medidas destinadas a estimular a } \\
\text { disseminação e crescimento desse mercado }\end{array}$ \\
\hline Transparência das operações bancárias & $\begin{array}{l}\text { Levantar informações mais detalhadas sobre juros } \\
\text { e encargos das principais operações de crédito e } \\
\text { divulgá-las, via internet, à população }\end{array}$ \\
\hline $\begin{array}{l}\text { Tratamento da dedução do IR/CSLL sobre } \\
\text { provisionamento de créditos }\end{array}$ & $\begin{array}{l}\text { Estudar a viabilidade de maior uniformização } \\
\text { desses procedimentos }\end{array}$ \\
\hline Observações & \\
\hline As informações desse quadro foram transcritas do relatório do PJSB de 2000. \\
\hline
\end{tabular}




\section{Título do documento}

Projeto Juros e Spread Bancário

\section{Data de publicação}

2001

\begin{tabular}{|c|c|}
\hline Medidas propostas & Objetivos \\
\hline $\begin{array}{l}\text { Ampliação da base de cobertura da Central de } \\
\text { Risco }\end{array}$ & Reduzir o limite de valor informado \\
\hline Aperfeiçoamento do Cosif & Aumentar a transparência dos balanços \\
\hline Aperfeiçoamento do sistema de pagamentos & $\begin{array}{l}\text { Consolidar legalmente as modificações que o BC } \\
\text { vem realizando no sistema }\end{array}$ \\
\hline Aumento de informações da Central de Risco & $\begin{array}{l}\text { Melhorar a qualidade das informações, inclusive } \\
\text { pela inclusão de informações positivas }\end{array}$ \\
\hline Contrato eletrônico de crédito & $\begin{array}{l}\text { Trabalhar pelo estabelecimento de uma lei que } \\
\text { regule a proteção das partes contratantes em } \\
\text { operações transitadas através da internet e de } \\
\text { outros meios eletrônicos }\end{array}$ \\
\hline Derivativos de crédito & $\begin{array}{l}\text { Possibilitar o uso desses instrumentos de redução } \\
\text { e transferência dos riscos de crédito }\end{array}$ \\
\hline $\begin{array}{l}\text { Esclarecimento sobre anatocismo (juros sobre } \\
\text { juros) no SFN }\end{array}$ & $\begin{array}{l}\text { Esclarecer que esse dispositivo da lei da usura } \\
\text { não se aplica ao SFN }\end{array}$ \\
\hline Flexibilização dos direcionamentos de crédito & $\begin{array}{l}\text { Propor medidas específicas que diminuam, em } \\
\text { geral, os direcionamentos das operações de } \\
\text { crédito rural }\end{array}$ \\
\hline Maior concorrência no cheque especial & $\begin{array}{l}\text { Promover maior transparência quanto aos } \\
\text { juros,encargos e outras condições praticadas } \\
\text { nessas operações }\end{array}$ \\
\hline Portabilidade de informações cadastrais & $\begin{array}{l}\text { Aumentar a concorrência bancária, autorizando } \\
\text { os clientes transfiram seus cadastros a outra } \\
\text { instituição financeira }\end{array}$ \\
\hline Promoção institucional da Central de Risco & $\begin{array}{l}\text { Esclarecer o papel dessa Central enquanto } \\
\text { instrumento de disseminação de informações } \\
\text { positivas }\end{array}$ \\
\hline Redução de exigências burocráticas & $\begin{array}{l}\text { Revisar um sem número de exigências que podem } \\
\text { ser consideradas excessivas em relação a } \\
\text { operações de pequeno valor }\end{array}$ \\
\hline Redução do IOF & $\begin{array}{l}\text { Reduzir o impacto do IOF nas operações de } \\
\text { crédito, principalmente para os empréstimos para } \\
\text { pessoas físicas }\end{array}$ \\
\hline Redução dos compulsórios & Redução dos compulsórios \\
\hline Securitização e negociação de recebíveis & $\begin{array}{l}\text { Tomar medidas destinadas a estimular a } \\
\text { disseminação e crescimento desse mercado }\end{array}$ \\
\hline Transparência das operações bancárias & $\begin{array}{l}\text { Levantar informações mais detalhadas sobre juros } \\
\text { e encargos das principais operações de crédito e }\end{array}$ \\
\hline
\end{tabular}




\begin{tabular}{|l|l|}
\hline & divulgá-las, via internet, à população \\
\hline $\begin{array}{l}\text { Tratamento da dedução do IR/CSLL sobre } \\
\text { provisionamento de créditos }\end{array}$ & $\begin{array}{l}\text { Estudar a viabilidade de maior uniformização } \\
\text { desses procedimentos }\end{array}$ \\
\hline Observações & \\
\hline As informações desse quadro foram transcritas do relatório do PJSB de 2001. \\
\hline
\end{tabular}




\section{Título do documento}

Economia Bancária e Crédito

\section{Data de publicação}

\begin{tabular}{|c|c|}
\hline Medidas propostas & Objetivos \\
\hline $\begin{array}{l}\text { Ampliação da base de cobertura da Central de } \\
\text { Risco }\end{array}$ & Reduzir o limite de valor informado \\
\hline Aperfeiçoamento do Cosif & Aumentar a transparência dos balanços \\
\hline Aperfeiçoamento do sistema de pagamentos & $\begin{array}{l}\text { Consolidar legalmente as modificações que o BC } \\
\text { vem realizando no sistema }\end{array}$ \\
\hline Aumento de informações da Central de Risco & $\begin{array}{l}\text { Melhorar a qualidade das informações, inclusive } \\
\text { pela inclusão de informações positivas }\end{array}$ \\
\hline Contrato eletrônico de crédito & $\begin{array}{l}\text { Trabalhar pelo estabelecimento de uma lei que } \\
\text { regule a proteção das partes contratantes em } \\
\text { operações transitadas através da internet e de } \\
\text { outros meios eletrônicos }\end{array}$ \\
\hline Derivativos de crédito & $\begin{array}{l}\text { Possibilitar o uso desses instrumentos de redução } \\
\text { e transferência dos riscos de crédito }\end{array}$ \\
\hline $\begin{array}{l}\text { Esclarecimento sobre anatocismo (juros sobre } \\
\text { juros) no SFN }\end{array}$ & $\begin{array}{l}\text { Esclarecer que esse dispositivo da lei da usura } \\
\text { não se aplica ao SFN }\end{array}$ \\
\hline Flexibilização dos direcionamentos de crédito & $\begin{array}{l}\text { Propor medidas específicas que diminuam, em } \\
\text { geral, os direcionamentos das operações de } \\
\text { crédito rural }\end{array}$ \\
\hline Maior concorrência no cheque especial & $\begin{array}{l}\text { Promover maior transparência quanto aos } \\
\text { juros,encargos e outras condições praticadas } \\
\text { nessas operações }\end{array}$ \\
\hline $\begin{array}{l}\text { Modificações nas regras de classificação das } \\
\text { operações de crédito e de constituição de } \\
\text { provisões }\end{array}$ & $\begin{array}{l}\text { Aumentar a segurança das operações de crédito, } \\
\text { disseminando uma melhor cultura de crédito no } \\
\text { País }\end{array}$ \\
\hline Portabilidade de informações cadastrais & $\begin{array}{l}\text { Aumentar a concorrência bancária, autorizando } \\
\text { os clientes transfiram seus cadastros a outra } \\
\text { instituição financeira }\end{array}$ \\
\hline Promoção institucional da Central de Risco & $\begin{array}{l}\text { Esclarecer o papel dessa Central enquanto } \\
\text { instrumento de disseminação de informações } \\
\text { positivas }\end{array}$ \\
\hline Redução de exigências burocráticas & $\begin{array}{l}\text { Revisar um sem número de exigências que podem } \\
\text { ser consideradas excessivas em relação a } \\
\text { operações de pequeno valor }\end{array}$ \\
\hline Redução do IOF & $\begin{array}{l}\text { Reduzir o impacto do IOF nas operações de } \\
\text { crédito, principalmente para os empréstimos para } \\
\text { pessoas físicas }\end{array}$ \\
\hline Redução dos compulsórios & $\begin{array}{l}\text { A diminuição dos recolhimentos compulsórios } \\
\text { contribui para a redução do spread bancário, mas }\end{array}$ \\
\hline
\end{tabular}




\begin{tabular}{|l|l|}
\hline & depende essencialmente da política monetária \\
\hline Securitização e negociação de recebíveis & $\begin{array}{l}\text { Tomar medidas destinadas a estimular a } \\
\text { disseminação e crescimento desse mercado }\end{array}$ \\
\hline Transparência das operações bancárias & $\begin{array}{l}\text { Levantar informações mais detalhadas sobre juros } \\
\text { e encargos das principais operações de crédito e } \\
\text { divulgá-las, via internet, à população }\end{array}$ \\
\hline $\begin{array}{l}\text { Tratamento da dedução do IR/CSLL sobre } \\
\text { provisionamento de créditos }\end{array}$ & $\begin{array}{l}\text { Estudar a viabilidade de maior uniformização } \\
\text { desses procedimentos }\end{array}$ \\
\hline Observações & \\
\hline As informações desse quadro foram transcritas do relatório do PJSB de 2002. \\
\hline
\end{tabular}




\section{Título do documento}

Economia Bancária e Crédito

\section{Data de publicação} 2003

\begin{tabular}{|l|l}
\hline Medidas propostas & Objetivos
\end{tabular}

Cartilha sobre portabilidade de informações cadastrais

Disseminar as informações aos consumidores quanto à possibilidade de acesso a seus cadastros e com isso aumentar a concorrência.

Realizar um esforço em grande escala junto a juízes, e à sociedade em geral, para mostrar que as decisões que beneficiam um tomador de

Conscientização de juízes empréstimo específico têm repercussões amplas, que podem prejudicar os tomadores de empréstimos como um todo, em nível mais abrangente.

Estudar a situação do FGC avaliando a

Contribuição do Fundo Garantidor de possibilidade de reduzir gradualmente as contribuições dos bancos, bem como a eventual Créditos (FGC) adoção de prêmio diferenciado pelo risco da instituição.

Flexibilizar os direcionamentos obrigatórios do crédito

Propor medidas específicas destinadas a reduzir os subsídios cruzados no crédito.

Com os avanços significativos em termos de detalhamento de informações, acessibilidade e

Implementar o novo Sistema de Informações de Crédito do Banco Central agilidade, a atual Central de Risco passará a estar disponível para consulta pelas instituições financeiras sob nova denominação.

Propor alternativas visando a redução de

Impostos indiretos sobre a intermediação impostos que incidem sobre o crédito (IOF) e a financeira intermediação financeira (PIS, Cofins, CPMF, etc).

A regulamentação tributária deveria procurar reconhecer as exigências contábeis das

Incidência de IR/CSLL sobre provisionamento de créditos instituições financeiras, já que são instituições diferenciadas, sob intensa regulação e fiscalização do BC.

Incluir litígios sobre créditos de baixo valor nos Tribunais de Pequenas Causas

Permitir que as instituições financeiras utilizem esses tribunais para a cobrança de créditos de pequeno valor.

Incorporar novas informações sobre tarifas bancárias no site do BC

Estudar a possibilidade de incluir os custos dos pacotes de tarifas dos diversos bancos, com o valor e a sua descrição.

Material explicativo para orientação sobre a Central de Risco de Crédito permitindo assim que os benefícios da Central de Risco fossem

Permitir que os benefícios da Central de Risco fossem amplamente conhecidos e as contestações 


\begin{tabular}{|c|c|}
\hline $\begin{array}{l}\text { amplamente conhecidos e as contestações } \\
\text { judiciais reduzidas. }\end{array}$ & judiciais reduzidas. \\
\hline $\begin{array}{l}\text { Melhorar o Cadastro Informativo dos créditos não } \\
\text { quitados do setor público federal - Cadin }\end{array}$ & $\begin{array}{l}\text { Modernizar o Cadin, de forma a torná-lo mais } \\
\text { amigável, no sentido de acessibilidade, e } \\
\text { disponível para consultas fora do setor público. }\end{array}$ \\
\hline $\begin{array}{l}\text { Modernizar os sistemas de registro de garantias } \\
\text { ao crédito }\end{array}$ & $\begin{array}{l}\text { Reformar a legislação sobre garantias ao crédito e } \\
\text { os seus sistemas de registro, de forma a } \\
\text { possibilitar um sistema mais moderno e } \\
\text { integrado, reduzindo custos e aumentando a } \\
\text { segurança dos usuários do sistema. }\end{array}$ \\
\hline $\begin{array}{l}\text { Redução de exigências burocráticas, racionalizar } \\
\text { e gerar ganhos de eficiência }\end{array}$ & $\begin{array}{l}\text { Reduzir o custo de crédito e portanto sobre a } \\
\text { magnitude do spread bancário. }\end{array}$ \\
\hline $\begin{array}{l}\text { Revisão da base legal relativa a informações e } \\
\text { relatórios de crédito }\end{array}$ & $\begin{array}{l}\text { Aumentar a proteção legal do Sistema de } \\
\text { Informações de Crédito do Banco Central e dos } \\
\text { cadastros privados de proteção ao } \\
\text { crédito. }\end{array}$ \\
\hline $\begin{array}{l}\text { Revisão na coleta de dados sobre operações de } \\
\text { crédito (Circular 2.957/99). }\end{array}$ & $\begin{array}{l}\text { Com a revisão na coleta de dados (Circular } \\
\text { 2.957/99) espera-se uma redução dos custos das } \\
\text { instituições financeiras, com ganho na qualidade } \\
\text { das informações obtidas e prestadas ao público. }\end{array}$ \\
\hline Separação juros/principal & $\begin{array}{l}\text { Permitir que, a critério do credor, seja } \\
\text { segmentado o processo de cobrança de dívidas, } \\
\text { de forma que possa o devedor executar a parcela } \\
\text { incontroversa de dívidas (em geral, o principal). }\end{array}$ \\
\hline Simulador de crédito & $\begin{array}{l}\text { Estimular ou induzir os bancos a terem em seu } \\
\text { site um simulador de crédito. }\end{array}$ \\
\hline $\begin{array}{l}\text { Transformação das MP em Leis: } \\
\text { - anatocismo (MP 2.170-36, de 23.08.2001) } \\
\text { - certificação de assinatura digital (MP 2.200-2, } \\
\text { de 24.08.2001) }\end{array}$ & \\
\hline \multicolumn{2}{|l|}{ Observações } \\
\hline & 3 \\
\hline
\end{tabular}




\section{Título do documento}

Relatório de Economia Bancária e Crédito

\section{Data de publicação}

\section{\begin{tabular}{|l|l}
\hline Medidas propostas & Objetivos
\end{tabular}}

Ampliação da base de cobertura da Central de Risco (atual Sistema de Informações de Crédito) do Banco Central

Cartilha sobre portabilidade de informações cadastrais

\begin{tabular}{|c|c|}
\hline adastrais & e com isso aumentar a concorrência. \\
\hline Conscientização de juízes & $\begin{array}{l}\text { Realizar um esforço em grande escala junto a } \\
\text { juízes, e à sociedade em geral, para mostrar que } \\
\text { as decisões que beneficiam um tomador de } \\
\text { empréstimo específico têm repercussões amplas, } \\
\text { que podem prejudicar os tomadores de } \\
\text { empréstimos como um todo, em nível mais } \\
\text { abrangente. }\end{array}$ \\
\hline Contrato eletrônico de crédito & $\begin{array}{l}\text { Trabalhar pelo estabelecimento de uma lei que } \\
\text { regule a proteção das partes contratantes em } \\
\text { operações transitadas através da internet e de } \\
\text { outros meios eletrônicos. }\end{array}$ \\
\hline Derivativos de crédito & $\begin{array}{l}\text { Possibilitar o uso desses instrumentos de redução } \\
\text { e transferência dos riscos de crédito. }\end{array}$ \\
\hline $\begin{array}{l}\text { Esclarecimento sobre anatocismo (juros sobre } \\
\text { juros) no SFN }\end{array}$ & $\begin{array}{l}\text { Esclarecer que esse dispositivo da lei da usura } \\
\text { não se aplica ao SFN. }\end{array}$ \\
\hline $\begin{array}{l}\text { Implementação do novo Sistema de Informações } \\
\text { de Crédito do Banco Central }\end{array}$ & $\begin{array}{l}\text { Aumentar o número e a qualidade das } \\
\text { informações disponíveis, assim como agilizar o } \\
\text { processo de consultas pelas instituições } \\
\text { financeiras. }\end{array}$ \\
\hline $\begin{array}{l}\text { Impostos indiretos sobre a intermediação } \\
\text { financeira }\end{array}$ & $\begin{array}{l}\text { Propor alternativas visando à redução de } \\
\text { impostos que incidem sobre o crédito (IOF) e a } \\
\text { intermediação financeira (PIS, Cofins, CPMF, } \\
\text { etc.). }\end{array}$ \\
\hline $\begin{array}{l}\text { Incidência de IR/CSLL sobre provisionamento de } \\
\text { créditos }\end{array}$ & $\begin{array}{l}\text { A regulamentação tributária deveria procurar } \\
\text { reconhecer as exigências contábeis das } \\
\text { instituições financeiras, já que são instituições } \\
\text { diferenciadas, sob intensa regulação e } \\
\text { fiscalização do BC. }\end{array}$ \\
\hline Maior concorrência no cheque especial & $\begin{array}{l}\text { Promover maior transparência quanto aos juros, } \\
\text { aos encargos e às outras condições praticadas } \\
\text { nessas operações. }\end{array}$ \\
\hline $\begin{array}{l}\text { Modificações nas regras de classificação das } \\
\text { operações de crédito e de constituição de } \\
\text { provisões }\end{array}$ & $\begin{array}{l}\text { Aumentar a segurança das operações de crédito, } \\
\text { disseminando uma melhor cultura de crédito no } \\
\text { País. }\end{array}$ \\
\hline
\end{tabular}

Reduzir o limite de valor informado. Disseminar as informações aos consumidores
quanto à possibilidade de acesso a seus cadastros e com isso aumentar a concorrência. empréstimo específico têm repercussões amplas, moréstimos como um todo, em nível mais

Trabalhar pelo estabelecimento de uma lei que regule a proteção das partes contratantes em operações transitadas através da internet e de Possibilitar o uso desses instrumentos de redução

Esclarecer que esse dispositivo da lei da usura aplica ao SFN. informações disponíveis, assim como agilizar o Propor alternativas visando à redução de intermediação financ diferenciadas, sob intensa regulação e zação do BC. aos encargos e às outras condições praticadas operações. disseminando uma melhor cultura de crédito no reconhecer as exigências contábeis das 


\begin{tabular}{|c|c|}
\hline Portabilidade de informações cadastrais & $\begin{array}{l}\text { Aumentar a concorrência bancária, autorizando } \\
\text { os clientes transfiram seus cadastros a outra } \\
\text { instituição financeira. }\end{array}$ \\
\hline $\begin{array}{l}\text { Promoção institucional do Sistema de } \\
\text { Informações de Crédito do Banco Central }\end{array}$ & $\begin{array}{l}\text { Esclarecer o papel dessa Central enquanto } \\
\text { instrumento de disseminação de informações } \\
\text { positivas. }\end{array}$ \\
\hline Redução de exigências burocráticas & $\begin{array}{l}\text { Revisar um sem número de exigências que podem } \\
\text { ser consideradas excessivas em relação a } \\
\text { operações de pequeno valor. }\end{array}$ \\
\hline Redução do IOF & $\begin{array}{l}\text { Reduzir o impacto do IOF nas operações de } \\
\text { crédito, principalmente para os empréstimos para } \\
\text { pessoas físicas. }\end{array}$ \\
\hline Redução dos compulsórios. & Redução dos compulsórios. \\
\hline $\begin{array}{l}\text { Revisão da base legal relativa a informações e } \\
\text { relatórios de crédito }\end{array}$ & $\begin{array}{l}\text { Aumentar a proteção legal do Sistema de } \\
\text { Informações de Crédito do Banco Central e dos } \\
\text { cadastros privados de proteção ao crédito. }\end{array}$ \\
\hline Securitização e negociação de recebíveis & $\begin{array}{l}\text { Tomar medidas destinadas a estimular a } \\
\text { disseminação e o crescimento desse mercado. }\end{array}$ \\
\hline Separação juros/principal & $\begin{array}{l}\text { Permitir a segmentação das parcelas controversas } \\
\text { nos processo de cobrança de empréstimos do } \\
\text { SFN, a exemplo da recente legislação específica } \\
\text { de contratos de financiamento imobiliário. }\end{array}$ \\
\hline Transparência das operações bancárias & $\begin{array}{l}\text { Levantar informações mais detalhadas sobre juros } \\
\text { e encargos das principais operações de crédito e } \\
\text { divulgá-las, via internet, à população. }\end{array}$ \\
\hline Observações & \\
\hline
\end{tabular}




\section{Título do documento}

Relatório de Economia Bancária e Crédito

Data de publicação

2005

\section{\begin{tabular}{|l|l}
\hline Medidas propostas & Objetivos
\end{tabular}}

Ampliação da base de cobertura da Central de Risco (atual Sistema de Informações de Crédito) do BC

Reduzir o limite de valor informado.

\begin{tabular}{|c|c|}
\hline Cadastro Positivo & $\begin{array}{l}\text { Regulamentar os bancos de dados privados de } \\
\text { proteção ao crédito, aumentando a proteção legal } \\
\text { das atividades relativas a informações e relatórios } \\
\text { de crédito. }\end{array}$ \\
\hline Contrato eletrônico de crédito & $\begin{array}{l}\text { Trabalhar pelo estabelecimento de uma lei que } \\
\text { regulamente a proteção das partes contratantes } \\
\text { em operações transitadas pela internet e por } \\
\text { outros meios eletrônicos. }\end{array}$ \\
\hline Derivativos de crédito & $\begin{array}{l}\text { Possibilitar o uso desses instrumentos de redução } \\
\text { e transferência dos riscos de crédito. }\end{array}$ \\
\hline $\begin{array}{l}\text { Elaboração de cartilha sobre portabilidade de } \\
\text { informações cadastrais }\end{array}$ & $\begin{array}{l}\text { Disseminar informações aos consumidores } \\
\text { quanto à possibilidade de acesso ao seu cadastro } \\
\text { e, com isso, aumentar a concorrência. } \\
\text { Observamos que, talvez por desconhecimento dos } \\
\text { clientes, a transferência de suas informações } \\
\text { cadastrais para outra IF está sendo pouco } \\
\text { utilizada, o que reduz o alcance da medida } \\
\text { adotada. }\end{array}$ \\
\hline $\begin{array}{l}\text { Esclarecimento sobre anatocismo (juros sobre } \\
\text { juros) no Sistema Financeiro Nacional (SFN) }\end{array}$ & $\begin{array}{l}\text { Esclarecer que esse dispositivo da lei da usura } \\
\text { não se aplica ao SFN. }\end{array}$ \\
\hline $\begin{array}{l}\text { Flexibilização dos direcionamentos obrigatórios } \\
\text { do crédito }\end{array}$ & $\begin{array}{l}\text { Propor medidas específicas, destinadas a reduzir } \\
\text { os subsídios cruzados no crédito }\end{array}$ \\
\hline Implementação do novo SCR do Banco Central & $\begin{array}{l}\text { Aumentar o número e a qualidade das } \\
\text { informações disponíveis e agilizar o processo de } \\
\text { consultas pelas IFs. }\end{array}$ \\
\hline $\begin{array}{l}\text { Incidência de IR/CSLL sobre provisionamento de } \\
\text { créditos }\end{array}$ & $\begin{array}{l}\text { A regulamentação tributária deveria reconhecer } \\
\text { as exigências contábeis das IFs, já que são } \\
\text { instituições diferenciadas, sob intensa regulação e } \\
\text { fiscalização do Banco Central. A regulação do } \\
\text { Banco Central é mais conservadora do que a da } \\
\text { Secretaria da Receita Federal (SRF) no que se } \\
\text { refere ao reconhecimento de créditos não } \\
\text { recebidos (inadimplência), o que faz com que as } \\
\text { IFs recolham IR/CSLL sobre receitas/lucros que } \\
\text { o Banco Central não reconhece (que passam a ser } \\
\text { registradas na contabilidade das IFs como } \\
\text { créditos tributários, passíveis de retornarem }\end{array}$ \\
\hline
\end{tabular}




\begin{tabular}{|c|c|}
\hline & $\begin{array}{l}\text { mediante abatimento do IR/CSLL de exercícios } \\
\text { futuros). }\end{array}$ \\
\hline $\begin{array}{l}\text { Melhorar o Cadastro Informativo dos créditos não } \\
\text { quitados do setor público federal (Cadin) }\end{array}$ & $\begin{array}{l}\text { Modernizar o Cadin, de forma que se torne mais } \\
\text { amigável quanto à acessibilidade e mais } \\
\text { disponível para consultas fora do setor público. }\end{array}$ \\
\hline $\begin{array}{l}\text { Modificações das regras de classificação das } \\
\text { operações de crédito e de constituição de } \\
\text { provisões }\end{array}$ & $\begin{array}{l}\text { Aumentar a segurança das operações de crédito, } \\
\text { disseminando melhor cultura de crédito no país. }\end{array}$ \\
\hline Portabilidade de informações cadastrais & $\begin{array}{l}\text { Aumentar a concorrência bancária, autorizando } \\
\text { os clientes a transferir seus cadastros a outra IF. }\end{array}$ \\
\hline $\begin{array}{l}\text { Promoção de mais concorrência no cheque } \\
\text { especial }\end{array}$ & $\begin{array}{l}\text { Proporcionar mais transparência quanto aos juros, } \\
\text { encargos e outras condições praticadas nessas } \\
\text { operações. }\end{array}$ \\
\hline Promoção institucional do SCR do Banco Central & $\begin{array}{l}\text { Esclarecer o papel dessa Central como } \\
\text { instrumento de disseminação de informações } \\
\text { positivas. }\end{array}$ \\
\hline Redução de exigências burocráticas & $\begin{array}{l}\text { Revisar exigências que podem ser consideradas } \\
\text { excessivas em relação a operações de pequeno } \\
\text { valor }\end{array}$ \\
\hline $\begin{array}{l}\text { Redução do Imposto sobre Operações Financeiras } \\
\text { (IOF) }\end{array}$ & $\begin{array}{l}\text { Reduzir o impacto do IOF nas operações de } \\
\text { crédito, principalmente para os empréstimos para } \\
\text { pessoas físicas. }\end{array}$ \\
\hline Redução dos compulsórios & $\begin{array}{l}\text { A diminuição dos recolhimentos compulsórios } \\
\text { contribui para o aumento da oferta de crédito e a } \\
\text { redução do spread bancário, mas essa redução } \\
\text { depende essencialmente da política monetária. }\end{array}$ \\
\hline Securitização e negociação de recebíveis & $\begin{array}{l}\text { Tomar medidas destinadas a estimular a } \\
\text { disseminação e o crescimento desse mercado. }\end{array}$ \\
\hline Separação juros/principal & $\begin{array}{l}\text { Permitir a segmentação das parcelas controversas } \\
\text { nos processo de cobrança de empréstimos do } \\
\text { SFN, a exemplo da recente legislação específica } \\
\text { de contratos de financiamento imobiliário. É } \\
\text { muito comum que devedores utilizem as } \\
\text { ineficiências e demoras dos processos judiciais } \\
\text { para adiar o pagamento de suas obrigações. Uma } \\
\text { das formas de fazer isso é questionar aspectos } \\
\text { menores, relacionados à cobrança dos encargos } \\
\text { financeiros devidos. Normalmente é muito difícil } \\
\text { para o devedor justificar irregularidades quanto } \\
\text { ao principal. }\end{array}$ \\
\hline Transparência nas operações bancárias & $\begin{array}{l}\text { Levantar informações detalhadas sobre juros e } \\
\text { encargos das principais operações de crédito e } \\
\text { divulgá-las à população pela internet. }\end{array}$ \\
\hline \multicolumn{2}{|l|}{ Observações } \\
\hline
\end{tabular}

\section{Título do documento}


Relatório de Economia Bancária e Crédito

\section{Data de publicação}

2006

\begin{tabular}{|l|l|}
\hline Medidas propostas & Objetivos \\
\hline
\end{tabular}

Medida Provisória 321, de 12.9.2006

Reduzir os custos dos financiamentos e desonerar operações destinadas ao setor habitacional

\begin{tabular}{|l|l|}
\hline Resolução 3.347, de 8.2.2006 & $\begin{array}{l}\text { Estabelecer novas medidas para dinamizar o } \\
\text { segmento imobiliário }\end{array}$ \\
\hline Resolução 3.401, de 6.9.2006 & $\begin{array}{l}\text { Minimizar riscos nas operações de crédito e de } \\
\text { leasing }\end{array}$ \\
\hline Resolução 3.402, de 6.9.2006 & $\begin{array}{l}\text { Permitir que o beneficiário escolha o banco para } \\
\text { o qual será direcionado o crédito de recursos } \\
\text { provenientes de salários, aposentadorias e } \\
\text { simulares. }\end{array}$ \\
\hline
\end{tabular}

\section{Observações}

O relatório de 2006 do PJSB não apresenta a mesma estrutura que os relatórios dos anos anteriores. Na seção que costumava dedicar-se às ações e medidas para redução do spread bancário, são expostas quatro medidas, todas já implementadas em 2006. Duas dessas medidas dizem respeito ao segmento de crédito direcionado.

As informações desse quadro foram transcritas do relatório do PJSB de 2006. 


\section{RESUMO}

O crédito bancário é a principal fonte de financiamento de pessoas físicas e jurídicas no Brasil. Ainda assim, comparações internacionais apontam que o mercado de crédito no Brasil é pequeno em volume de empréstimos concedidos, limitado em número de instrumentos e caro nos preços praticados.

O propósito desta tese é apreender as expectativas em relação ao direito supostas em documentos oficiais do Banco Central do Brasil (BCB) que sugeriram, entre 1999 e 2006, medidas para a reversão desse quadro. Para tanto, analisa os argumentos apresentados para a implementação de um conjunto específico de medidas de reforma jurídica dos sistemas de insolvência e de cobrança de dívidas, considerados cruciais para o desenvolvimento financeiro.

Como resultado da análise, foi possível identificar um continuum discursivo entre as justificativas apresentadas pelos documentos oficiais do BCB para a adoção das medidas de reforma do mercado de crédito e o que se designou de perspectiva da dotação institucional. Segundo essa visão, a clara definição de direitos de propriedade e eficientes mecanismos para o cumprimento de contratos são precondições essenciais para o crescimento econômico.

Palavras-chave: Banco Central do Brasil; Law and Finance; dotação institucional; mercado de crédito; direitos dos credores. 


\begin{abstract}
Bank loans are the main source of financing for individuals and corporations in Brazil. Nevertheless, when compared to those of other countries, the credit market in Brazil is still small in the overall amount of loans, limited in the number of loan instruments and expensive for borrowers.

The present dissertation aims at identifying the role assigned to Law by official Brazilian Central Bank (BCB) documents tackling this problem issued between 1999 and 2006. In order to do so, it analyses the arguments used to justify a set of specific measures intending to reform the legal framework for dealing with two key elements for the development of the credit market: default and forfeiture.

It is argued that there is a discursive continuum between the arguments present in the official BCB documents aimed at the reform of the credit market and the tenets of what is called institutional endowment. According to these tenets, the clear definition of property rights and efficient means for contract enforcement are pre-conditions for economic development.
\end{abstract}

Key-words: Brazilian Central Bank; Law and Finance; institutional endowment; credit market; creditor rights. 


\section{RÉSUMÉ}

Le crédit bancaire représente la source principale de financement de personnes physiques et morales au Brésil. Et pourtant, des comparaisons internationales montrent que le marché de crédit au Brésil est infime en volume d'emprunts décernés, limité en ce qui concerne le nombre d'instruments et cher par rapport aux prix pratiqués.

Le propos de cette thèse est de saisir les expectatives par rapport au droit supposées en documents officiels de la Banque Centrale du Brésil (BCB) qui ont suggéré, entre 1999 et 2006, des mesures pour la réversion de ce cadre. Pour cela, on analyse les arguments présentés pour la mise en place d'un ensemble spécifique de mesures de reforme juridique des systèmes d'insolvabilité et de recouvrement de dettes, considérés décisifs pour le développement financier.

Comme résultat de cette analyse, il a été possible d'identifier un continuum discursif entre les justifications présentées par les documents officiaux du BCB pour l'adoption des mesures de reforme du marché du crédit et ce que l'on a désigné de perspectives de la dotation institutionnelle. Selon ce point de vue, l'évidente définition de droits de propriété et des mécanismes efficaces pour l'accomplissement de contrats sont des conditions préalables essentielles pour la croissance économique.

Mots-clés: Banque Centrale du Brésil; Law and Finance; dotation institutionnelle; marché de crédit; droits des créanciers. 